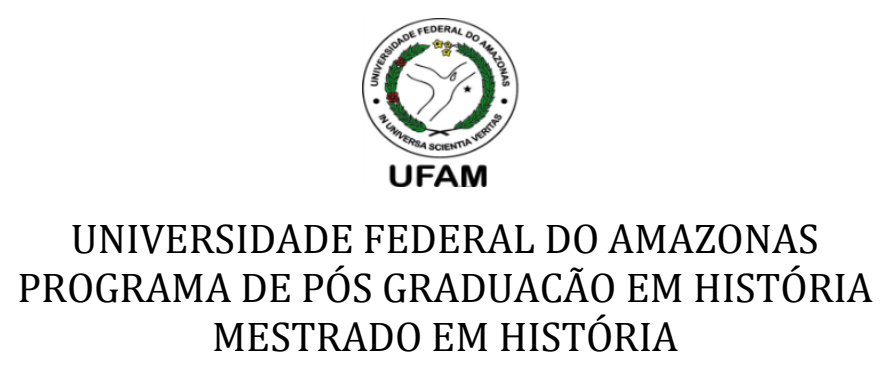

RAimundo Alves PEREIRA Filho

LUPANARES E PUTEIROS:
Os Últimos SuSPIROS Do RENDEZ-VOUS NA SOCIEDADE MANAUARA
$(1959 / 1969)$

Manaus

Fevereiro de 2014 


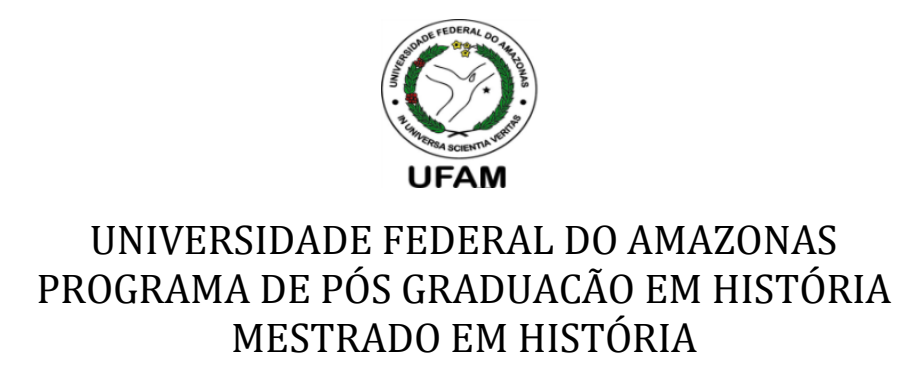

RAIMUNDO AlVEs PEREIRA FilHo

\title{
LUPANARES E PUTEIROS: \\ Os Últimos SUSPIROS DO RENDEZ-VOUS NA SOCIEDADE MANAUARA (1959/1969)
}

\author{
Orientador: \\ Prof. Dr. Luís Balkar Sá Peixoto Pinheiro
}

Dissertação apresentada ao Programa de Pós-Graduação em História da Universidade Federal do Amazonas, como requisito para a obtenção do título de Mestre em História.

Manaus

Fevereiro de 2014 
Ficha Catalográfica

(Catalogação realizada pela Biblioteca Central da UFAM)

Pereira Filho, Raimundo Alves

P4361 Lupanares e puteiros: os últimos suspiros do Rendez-vous na sociedade Manauara / Raimundo Alves Pereira Filho. - Manaus, 2014.

$132 \mathrm{f}$.

Dissertação (mestrado em História) - Universidade Federal do Amazonas.

Orientador: Prof. Dr. Luís Balkar Sá Peixoto Pinheiro

1. Prostituição 2. Bordel 3. Prostituição I. Pinheiro, Luíz Balkar Sá Peixoto (Orient.) II. Universidade Federal do Amazonas III. Título 


\section{TERMO DE APROVAÇÃO}

BANCA EXAMINADORA

Prof. Dr. Luís Balkar Sá Peixoto Pinheiro (UFAM - Presidente)

Prof. Dr. Almir Diniz de Carvalho Júnior (UFAM - Membro)

Prof. Dr. Edgar Ávila Gandra (UFPEL - Membro) 
Dedicado a meu tio Judicael da Silva Almeida, que num lampejo de premonição, proporcionou as minhas retinas um único olhar ao objeto dessa pesquisa, tanto quanto aguçou meu espirito em buscar sempre o incomensurável das coisas numa prazerosa caminhada sem destino. 
Ao encontro eterno que tive no "Lá Hoje" Iniciado na hora do "Ângelus", No límpido igarapé do "Piscina Clube" Onde nos braços tinha minha pequena "Iracema"

Com uma linda "Rosa de Maio" nos seios, Sob o olhar cândido e aprovador Da negra "Verônica" Disse-lhe um Adeus! 


\section{AGRADECIMENTOS}

Agradeço a todos os que de uma forma ou de outra contribuíram para a realização desta dissertação e particularmente a;

Professor Doutor Geraldo Sá Peixoto Pinheiro, patrono de todos os historiadores de nossa geração, que teve um papel preponderante na germinação desse trabalho ainda nos idos de 1998 e que, com incentivos, acompanhou até este momento;

Ao Professor Doutor Luís Balkar Sá Peixoto Pinheiro, meu orientador, pelo enorme esforço de me direcionar para o viés acadêmico, me afastando da prosa;

Ao Professor Doutor Almir Diniz de Carvalho Júnior, por ter participado ativamente em toda a minha vida acadêmica no curso de História da graduação até o atual estágio; À Professora Doutora Patrícia Rodrigues da Silva pela incomensurável contribuição na qualificação;

As amigas dos tempos de graduação que colaboraram atônitas sobre a pesquisa de meu tema: Daniela Brandão Clementino, Mara Pilipenko, Carla Lima e, principalmente, Andrea Nascimento, que contribuiu nas pesquisas com os jornais na Biblioteca Pública do Estado do Amazonas;

Aos mestres da UNINORTE, Arcângelo Ferreira, incentivador de todas as horas, Adriana Barata que me mostrou os pecados da Idade Média; e à Ana Paula Rabêlo que me auxiliou no projeto de pesquisa;

Aos colegas mestrandos, hoje mestres, Rosineide Gama, Jordan Lima Perdigão e Isley Raposo, pelos carinhos dedicados em horas difíceis;

À minha família, por não ter aumentado meus encargos enquanto realizava a pesquisa.

À memória, produto e sujeito desta viagem, por me embalar carinhosamente nas nebulosas de Clio;

E a minha Amada Mãe, Catarina Almeida Pereira por ter me dado e ensinado vida!

À todos o meu muito obrigado! 



\section{RESUMO}

Esta é uma dissertação sobre os lupanares e puteiros existentes na cidade de Manaus na década de sessenta. 0 método usado, já consagrado na História Oral, foi o de entrevistas com "putanheiros" e frequentadores que vivenciaram o apogeu desses bordéis. Dentro dos ditames da História Cultural foram utilizadas as diretrizes de Edward Palmer Thompson e Roger Chartier na abordagem teórica. Os puteiros e lupanares foram os últimos bordéis denominados de "rendez-vous" que surgiram na França e seu modelo foi importado para Manaus no "boom" da economia gumífera. Contextuando, percorremos o trajeto dos bordéis modernos desde seu nascedouro no século XIX até seu desaparecimento em meados do século XX. Em Manaus abordamos seu nascedouro e acompanhamos seu desenvolvimento até a década de cinquenta, quando surge o primeiro puteiro com determinadas características que perdurariam predominantemente até meados da década de setenta. Sobre os puteiros e lupanares foram expostas as representações, através de costumes, hábitos e comportamentos dos putanheiros e seus relacionamentos com as prostitutas dentro e fora daqueles recintos; o espaço ocupado pelos lupanares dentro da cidade; a especificidade dos igarapés em sua arquitetura; a reação da sociedade, filtrada através dos jornais e da repressão policial; o golpe recebido pela ascensão da contracultura e finalmente sua substituição pelos motéis como local da atividade de sexo pago, sacramentando sua extinção.

Palavras-chave: Bordel, Lupanares, Puteiros, Prostituição, Sexualidade. 


\section{ABSTRACT}

This is a dissertation about the brothels and whorehouses existing in the city of Manaus in the sixties. The method is already used in oral history, was the interviews with "putanheiros" and regulars who experienced the heyday of these brothels. Within the dictates of the Cultural History guidelines Edward Palmer Thompson and Roger Chartier were used in the theoretical approach. The whorehouses and brothels were the last brothels called "rendez-vous" that emerged in France and was imported to Manaus on the "boom" of gumífera economy. Walked the path of modern brothels from its origin in the nineteenth century until its demise in the mid- twentieth century. In Manaus approached its birth and followed until the fifties, when the first whorehouse with certain characteristics arises predominantly and lasted until the mid seventies. On brothels and whorehouses were exposed to representations, through customs, habits and behaviors of "putanheiros" and their relationships with prostitutes in and out of the whorehouses, the space occupied by brothels within the town, the specificity of the creeks in its architecture, the reaction society through newspapers and police repression, the blow dealt by the rise of the counterculture, and finally replacing the motels like activity site paid sex extinction.

Keywords: Brothel, Brothels, Horehouses, Prostitution, Sexuality. 


\section{SUMÁRIO}

Considerações Iniciais

$\begin{array}{ll}\text { Capítulo } 1 \text { - Abordagens e antecedentes. } & 17\end{array}$

1.1. Algumas considerações metodológicas $\quad 17$

1.2. A breve vida dos bordéis clássicos. 28

1.3. Das fontes, aguadas e lavadouros às "pensões de artistas" no Brasil. 40

Capítulo 2 - Rendez-vous, lupanares e puteiros na cidade de Manaus. $\quad 53$

2.1. Os bordéis na Belle Époque manauara.

2.2. Puteiros: Entre práticas e representações $\quad 68$

2.3. 0 apogeu dos puteiros na década de 1960 em Manaus. $\quad 81$

Capítulo 3 - Metamorfose: Dos puteiros aos motéis. 95

3.1. Os últimos suspiros dos puteiros: travessias do público ao privado. 95

3.2. A contracultura e as novas representações das práticas sexuais. 104

3.3. Os motéis entram em cena. 113

$\begin{array}{ll}\text { Considerações finais. } & 122\end{array}$

$\begin{array}{lr}\text { Referências. } & 127\end{array}$ 


\section{CONSIDERAÇÕES INICIAIS}

Num amanhecer de um domingo qualquer de setembro, pouco antes do Exame de Qualificação, percorri os locais onde se situavam os puteiros que existiram na década de sessenta. Passando pela estação rodoviária - já naquele horário em plena atividade - demorei um pouco e, por segundos, as imagens das pessoas se misturaram às lembranças dos meus entrevistados e, dessa forma, o local e as pessoas embaralharam minha mente, até a buzina dos carros me fazer voltar à realidade e perceber que aquelas pessoas, agora em tempos diferentes, eram apenas passageiros.

Continuei pela Avenida Torquato Tapajós, pedi ao porteiro do condomínio do Conjunto Habitacional Kennedy que me permite-se a entrada e após passar pelas casas, adentrei por uma trilha, numa pequena capoeira, que me levou a um igarapé com corrente firme, porém, todo poluído. A areia fina e branca imantada de folhas secas cobria as duas margens e os olhos de um jacaré quieto na água me fitavam como a perguntar o que eu estava fazendo ali. Pergunta que eu mesmo fazia àquela paisagem. 0 que aquele local ainda fazia ali? 0 porteiro, incrédulo, vinte metros atrás de mim, como quisesse responder, tossiu, e fez um gesto me convidando a sair.

A pouco mais de trezentos metros, na mesma avenida, estacionei o carro em frente ao Millennium Shopping, e segui para debaixo da ponte da Cachoeira Grande, caminhando entre latas de cervejas e vidros quebrados. Cheguei à margem do igarapé de cor escura e poluído, sentei-me num tronco deixado ali por alguma enxurrada e, percorrendo seu leito lentamente, meu olhar se fixou em duas grandes pedras na outra margem. Não pude resistir a imaginar três ou mais prostitutas se bronzeando de maiô e tive a nítida sensação que sorriam para mim, como a me chama para um mergulho no límpido riacho de outrora. Novamente o silvo do guarda municipal me trouxe à realidade. Queria saber o que eu estava fazendo ali, já que ali não tinha para ser visto. Achei por bem não responder, e fui embora.

Passava das nove horas e eu retornei pela Avenida Constantino Nery, seguindo até a frente o hospício, para em seguida entrar à direita numa pequena 
via, entre uma loja de ferragem e outra de brinquedos, para depois de percorrer uns sessenta metros, chegar à confluência da Rua Recife. 0 local estava com capim muito alto, com mais de metro e meio, onde se via uma velha casa de alvenaria destelhada e um ténue sinal do antigo igarapé, hoje submerso pela vegetação repleta de buritizeiros. Atravessando a avenida pude, enfim, observar o esgoto em que se transformou o igarapé, e perdi-me novamente nas lembranças dos entrevistados, a imaginar se ali realmente existiu todas as coisas que me foram relatadas. Foi quando a visão de uma capivara atravessando languidamente a água poluída, me serviu de resposta: sim, existiu vida antes, e existe vida agora.

Retornei pela rotatória do Amazonas Shopping e pegando novamente a Torquato Tapajós passei da entrada da Cidade Nova e, na primeira rua, virando à direita, entrei na Rua Rosa de Maio. Já havia percorrido os trezentos metros e nada de igarapé, nada de vestígios do passado. Dobrei à direita e, numa pequena feira, estacionei. Olhava para todos os feirantes em busca de encontrar o mais velho, alguém que pudesse me informar sobre a exata localização do que eu procurava. Escolhi o peixeiro e lhe perguntei: 0 senhor pode me informar onde ficava o puteiro Rosa de Maio? Ele negou com a cabeça e voltei. Já ia embora quando ouvi uma voz jovem me dizendo: "é logo ali embaixo, após essa rua. Pertencia a minha vó". Era o ajudante do peixeiro. 0 resto do que foi o igarapé estava quase todo aterrado e, como os outros, poluído.

Fazendo o retorno na entrada do Aeroporto dirigi por mais um quilometro, passando em frente a um depósito e depois a um colégio, cheguei ao local onde, na década de setenta, existiram o Selvagem e o Saramandaia. Reduzi a macha e, no Posto 5, entrei numa pequena entrada, hoje tomada, nos dois lados, por borracheiros de caminhões e despachantes. A poucos metros do igarapé entrei num restaurante e indaguei de supetão a um senhor que estava sentado na mureta: "era aqui que ficava o Piscina"? Ele me olhou com assombro e respondeu: "sim, mas era do outro lado, aqui tinha uma ponte de madeira", respondeu apontando o local da ponte. "Era muito bonito eu ainda chequei a vir aqui uma vez quando jovem. Era muito longe". Olhando para aquele senhor eu fiquei a me perguntar se os meus entrevistados nunca tiveram a curiosidade de voltar ali.

Esses seis locais percorrido numa manhã, são o objeto desta pesquisa. Era naqueles espaços que funcionaram o "Lá hoje", "Shangri-lá", "Verônica”, "Ângelos", 
"Rosa de Maio" e "Piscina Club". Estes foram os principais lupanares e puteiros da cidade de Manaus na década de 1960.

Nesse mergulho em direção ao passado, lancei mão de diversos vestígios e fontes, como os jornais da época e as entrevistas com putanheiros ${ }^{1}$ e frequentadores. Estes últimos são aqui entendido como aqueles:

que tem a possibilidade do movimento, da transitoriedade [...] Por exemplo, poderá fazer programa, poderá apenas olhar as prostitutas, beber, ser dono de casa, ser namorado, ser contrário à atividade da prostituição, ser taxista, entre outras. ${ }^{2}$

Os ditames da Historia oral foram utilizados na abordagem das fontes oriundas das entrevistas com garçons, gerentes e proprietários de lupanares, de um lado, e com putanheiros oriundos de diversas profissões, notadamente funcionários públicos, comerciantes, jornalistas, radialistas e choferes de praça, além de dona-de-casa e moças da época; todos testemunhando suas experiências, expectativas, apreensões e medos em suas múltiplas relações com os puteiros. Nas entrevistas feitas utilizando como instrumento a gravação, onze ao todo, e duas em vídeo, buscamos compreender, dentro da experiência e da lembrança de vida do entrevistado, o que há de consciência coletiva e o que e o quanto o puteiro foi importante em suas relações afetivas e sexuais. Quanto a essa dimensão metodológica, Paul Thompson assim esclarece:

\begin{abstract}
A evidência oral, por assumir a forma de história de vida, traz à tona um dilema subjacente a toda interpretação histórica. A vida individual é o veículo concreto da experiência histórica. Além disso, a evidencia, em cada história de vida, só pode ser plenamente compreendida como parte da vida como um todo. Porém, para tornar possível a generalização, temos que extrair a evidencia sobre cada tema de uma série de entrevistas, remontando-a para enxergá-la de um novo ângulo, como que horizontalmente em vez de verticalmente; e, ao fazê-lo, atribuir-lhe um novo significado. ${ }^{3}$
\end{abstract}

De acordo com Sônia Maria de Freitas4, a metodologia usada pela história oral se divide em três gêneros distintos: a que trabalha com a tradição oral, a de

\footnotetext{
${ }^{1}$ Putanheiro é aqui entendido como: 1) 0 homem que está sempre em busca de aventuras sexuais; "comedor"; "femeeiro"; "galinha"; "mulherengo". 2) Homem que gosta de relacionar-se sexualmente com prostitutas. [F.: puta + eiro.], conforme http://aulete.uol.com.br/ (dicionário online).

2 PASINE, Elisiane. Os homens da vila: um estudo sobre relações de gênero num universo de prostituição feminina. Tese de Doutorado. Campinas: UNICAMP, 2005, p. 18.

3 THOMPSON, Paul. A Voz do Passado - História oral. São Paulo. Paz e Terra. 1992. 302.

${ }^{4}$ FREITAS, Sônia Maria de. História Oral: Possibilidades e procedimentos. São Paulo. Associação Editorial Humanitas, 2006, p. 21.
} 
história de vida e a história temática. Elegemos esta última para nossa pesquisa, não só para tentar obter dados substanciais sobre o objeto da pesquisa, mas também para tentar ter uma visão geral sobre as representações coletivas, para isso escolhemos o tema e ao redor dele fixamos as perguntas, posto que,

\begin{abstract}
A entrevista tem caráter temático e é realizada com um grupo de pessoas, sobre um assunto especifico. Essa entrevista - que tem característica de depoimento - não abrange necessariamente a totalidade da existência do informante. Dessa maneira, os depoimentos podem ser mais numerosos, resultando em maiores quantidades de informações, o que permite uma comparação entre eles apontando divergências, convergências e evidencias de uma memória coletiva, por exemplo. 5
\end{abstract}

No decorrer das entrevistas e nas analises feita procuramos ter o cuidado de perceber o que vai além do fato relatado, sem, contudo, descaracterizá-la, e de acolher esses relatos como lembranças de um passado distante, mais com todo o peso das experiências vividas desde então pelos entrevistados, de modo que,

\begin{abstract}
0 retorno do passado nem sempre é um momento libertador da lembrança, mas um advento, uma captura do presente. Vinda não se sabe de onde, a lembrança não permite ser deslocada; pelo contrário, obriga uma perseguição, pois nunca está completa. A lembrança insiste porque de certo modo é soberana e incontrolável (em todos os sentidos dessa palavra). Poderíamos dizer que o passado se faz presente. E a lembrança precisa do presente porque como assinalou Deleuze a respeito de Bergson, o tempo próprio da lembrança é o presente: isto é, o único tempo apropriado para lembrar e, também, o tempo do qual a lembrança se apodera, tornando-o próprio. ${ }^{6}$
\end{abstract}

A pesquisa em jornais da década de sessenta foi abordada de forma a perceber as similitudes e desacordos entre os discursos dos entrevistados e o que era noticiado nos jornais. 0 posicionamento defendido pelos matutinos, quase sempre contrário a existências dos puteiros, tinham ares de estar ajudando no processo civilizador que a cidade necessitava. A suposta neutralidade da notícia não resiste a uma análise do discurso, tão evidente a tendenciosidade, capaz de saltar aos olhos dos mais ingênuos.

Por fim, justapondo-se e contrapondo-se os resultados das pesquisas nas diversas fontes utilizadas, buscou-se compreender o que era, onde se localizavam,

\footnotetext{
${ }^{5}$ FREITAS, Maria de. História Oral. Op. cit., p. 21.

6 SARLO, Beatriz. Tempo Passado: Cultura da memória e guinada subjetiva. São Paulo: Cia das Letras, 2007, p. 10.
} 
quem eram seus usuários e porque os puteiros e lupanares, tendo adquirido ampla aceitação no interior da sociedade desapareceram.

A dissertação está dividida em três capítulos. O primeiro deles, "As abordagens e os antecedentes", subdivide-se em três tópicos, sendo o primeiro deles dedicado à questões metodológicas, onde busca-se apresentar o objeto e as vertentes teóricas da História Cultural, que mais influenciaram esta pesquisa. No tópico seguinte discorro sobre o surgimento, desenvolvimento e extinção dos bordeis, para, finalmente, comentar sobre a entrada e o caminho percorrido por eles no solo brasileiro.

No primeiro tópico foram utilizadas principalmente as seguintes obras: $\grave{A}$ beira da falésia, de Roger Chartier; As peculiaridades dos ingleses, Costumes em comum e A miséria da teoria, todas de Edward Palmer Thompson. Já no segundo tópico foi bastante utilizada a obra Os bordéis franceses (1830-1930), de Laure Adler, posto que ela nos direcionou ao estudo das novas formas de bordéis no mundo, iniciado na França, para então ser copiado em todas as partes do mundo, inclusive em Manaus até a década de 60 do século XX.

Para embasar o terceiro tópico, seguiu-se como linha mestra, o trabalho de Guido Fonseca História da prostituição em São Paulo, em toda a sua extensão, e Histórias íntimas, de Mary Del Priore, notadamente o capítulo primeiro, em que a autora trata da América portuguesa, na transição e durante o Império. Outra obra esclarecedora foi a dissertação de Luiz Carlos Soares, Rameiras, ilhoa, polacas...: A prostituição no Rio de Janeiro do Século XIX.

No alvorecer da República e em seus primeiros passos já dentro do século XX, exuberante como a Belle Époque, sorvermos o arcabouço da obra de Margareth Rago, Os prazeres da noite. Outra brilhante contribuição foi à obra Prostituição: uma visão global, de Armando Pereira, esmiuçando o que do exterior adentrou no Brasil e a singularidade do Mangue no Rio de Janeiro. Digno de nota foi também o romance de Esther Largman, Jovens Polacas: da miséria na Europa à prostituição no Brasil, livro que de uma forma concisa explica o drama das prostitutas judias que vieram para o Brasil.

Para a década de 1940 e 1950, além das obras de Fonseca, Del Priore e de Rago, recorreu-se ao romance de Lucius Mello Eny e o grande bordel brasileiro, que além de servir neste capítulo como fonte histórica, foi também importante, nos 
capítulos seguintes, para a análise da ponte entre o bordel e o motel. Por fim, a obra de Barruel Lagenest, Lenocínio e prostituição no Brasil, que, por ser editado em 1960 e ter como conteúdo pesquisas feita entre 1958 e 1959. foi de uma utilidade impar neste capítulo.

No primeiro item do capítulo segundo, buscou-se a origem do bordel na cidade de Manaus, ali sendo percorridos os diversos momentos pelos quais a cidade passou desde quando era majoritariamente habitada por índios e mamelucos que moravam em palhoças humildes, passando pelas impactantes transformações da segunda metade do século XIX, observando o "boom" populacional e arquitetônico da época áurea da borracha e a debandada geral ocorrida após o definhamento da produção gumífera, e o realinhamento econômico dos anos quarenta e cinquenta com o cultivo da juta, até ao final da década de sessenta quando foram instalados os primeiros projetos industriais com a implantação da Zona Franca.

As principais obras utilizadas para embasar esse item foram compostas por historiadores e memorialistas. Na descrição de Manaus desde sua fundação até a Belle Époque utilizamos os seguintes trabalhos; como pano de fundo, Fundação de Manaus: pródromos e sequências, de Agnello Bittencourt, com suas citações de relatos de viajantes de diversas épocas e com uma visão concisa, modelou o conhecimento da época anterior a euforia gumífera (1880-1920). Auxiliando e complementando esse período, foi utilizada a obra Barés, Manáos e Tarumãs, de José Ribamar Bessa Freire, importante trabalho de resgate de agentes históricos esquecidos pela historiografia oficial. Esta obra também deu embasamento ao estudo do período áureo da borracha, juntamente com o livro $A$ cidade sobre os ombros: Trabalho e conflito no porto de Manaus, de Maria Luzia Ugarte Pinheiro, que além de contextuar todo o período, ainda serviu de fonte para pesquisa sobre a prostituição na "zona estragada" do porto de Manaus.

Além dos livros acima citados, a prostituição na Belle Époque foi ricamente abordada por Leno José Barata Souza com seu trabalho Eva, vadios e moleques. Como se verá teve o mérito de mostrar outras formas de prostituição fora aquela dos luxuriosos bordéis, com suas francesas e polacas. Para se comparar o tipo de prostituição praticada em Manaus e na cidade de Belém, também na efervescência 
da economia gumífera, foi utilizado o depoimento de Maria de Nazaré Sarges, em seu livro Belém: riquezas produzindo a Belle Époque (1870-1912).

Outra fonte importante de pesquisa foram os depoimentos contidos nas obras dos memorialistas. A atenção dada a esses exercícios de memória buscou seguir os procedimentos críticos comuns para quaisquer fontes histórica, fossem escritas, visuais ou orais. Thiago de Mello, em Manaus amor e memória, revela-nos, de forma poética e sucinta, o cotidiano e a origem das prostitutas "francesas, russas, polacas” que gravitaram por Manaus; Já João Nogueira da Mata, em Amazônia: Terra da promissão, contextualiza a noite boêmia nas "pensões luxuosas" e o retorno "as cidades de origem" das prostitutas estrangeiras "endinheiradas".

Dos anos trinta aos anos cinquenta, a contextualização se fez quase que exclusivamente por memorialista. Mello nos releva a transição, ou troca, efetuada no plantel das prostitutas, causada pela carência de dinheiro. Com isso, saiam de cena as francesas refinadas e entravam, em grande volume as "caboclas peitudas". Outro memorialista de destaque, Jefferson Péres, detalha, em Evocações de Manaus como eu vi ou sonhei, a decoração e o cotidiano de uma "pensão" na década de quarenta.

A década de sessenta foi contemplada com historiadores, economistas, geógrafos, memorialistas e entrevistas de frequentadores dos puteiros. Em vista panorâmica, a obra de José Vicente de Souza, Manaus praça, colégio e cinema anos 50 e 60, revela uma Manaus em transição, de cidade bucólica à cidade efervescente, salientando o espanto do homem ante essas transformações. Para situarmos as economias do Amazonas e de Manaus na década em estudo foram manuseados os seguintes livros: $O$ desenvolvimento do capitalismo em Manaus, de Márcio Alexandre Moreira, que utilizando o arcabouço conceitual de Marx e do marxismo mostrou a deficiência da não acumulação de capital para justificar a permanência do extrativismo, ladeado pelo cultivo da juta; Wilson Rodrigues da Cruz esmiúça a cultura da juta "a mais rendosa das atividades agrícolas da região" e por fim José Lopes Silva afirma que a juta, em 1964, representa 34\% da economia regional, em seu livro Amazonas: do extrativismo à industrialização.

No tópico seguinte, onde foi dada ênfase ás informações colhidas nas entrevistas, buscamos visualizar a geografia do prazer, as representações e os 
relacionamentos entre clientes e prostitutas e foram foi utilizados as seguintes obras Manaus, praça, colégio e cinema anos 50 e 60, de José Vicente de Souza; $O$ conceito de Território na geografia da prostituição, de Jan Carlos da Silva; Bordeis, bordeis: negociando identidades, de Renan Springer Freitas e a tese Identidade de gênero, amor e casamento em Teresina, de Elizangela Barbosa Cardoso, entre outros autores e livros que serviram como suporte teórico ao tópico.

No tópico seguinte procuramos demonstrar a hegemonia desses estabelecimentos na década de sessenta e os ataques por eles sofridos, notadamente pela imprensa e pela polícia. Além da ênfase nas entrevistas, foram reportadas as notícias dos periódicos da época.

No terceiro capítulo, "Metamorfose: dos puteiros aos motéis", foi trabalhada a extinção dos puteiros e lupanares da cidade de Manaus. No tópico primeiro foram relatadas algumas notícias de jornais dando conta do fechamento de prostíbulos, como também das resistências dos puteiros. Mais uma vez foram as entrevistas e os recortes de jornais, o "corpus" mais utilizado com suporte à pesquisa. No tópico seguinte foram analisadas as mudanças de comportamentos e das práticas sexuais de uma geração para outra, tendo como contexto o advento da contracultura. As obras consultadas foram Histórias íntimas, de Mary Del Priore; Práticas sexuais. A história da sexualidade humana, de Edgar Gregersen; Mulheres, adúlteros e padres, de Lana da Dama Lima; Virando as páginas: revendo as mulheres, 1945-1964, e A década de 60: Rebeldia, contestação e repressão política, de Maria Helena Simões. No último tópico foi feita um breve apanhado da história dos motéis e as reações dos putanheiros da década de sessenta ante a extinção dos lupanares e puteiros. Além das entrevistas, as principais obras foram Arquitetura de motéis cariocas: Espaço e organização social, de Lauro Cavalcanti, em especial pela análise sugerida no relativo aos motéis e Prostituição: desafio à sociedade e à igreja, editada pela CNBB; Memórias do meu tempo, de Obama Cesar Ituassú, além do já citado Evocações de Manaus como eu vi ou sonhei, de Jefferson Péres, além é claro das entrevistas. 


\section{CAPÍTULO 1 \\ ABORDAGENS E ANTECEDENTES:}

\subsection{Algumas Considerações Metodológicas}

No final da década de sessenta do século XX, na cidade de Manaus, o alto e o médio meretrício eram realizados por determinados rendez-vous que a imprensa denominava lupanares, antros de prostituição e casas de perdição, entre outras denominações, mas seus frequentadores o chamavam simplesmente de puteiros. Herdeiros das "pensões" e bordéis fechados, que brotaram na Belle Époque e minguaram nas décadas de quarenta e cinquenta daquele século, os puteiros conquistaram espaços, impondo seus valores e estilos, ancorados na acolhida de prática sexual em que prostitutas ofereciam seus corpos à preços módicos para clientes sedentos de aventuras e prazer. Assumiam também características próprias na forma como ali se processavam as relações entre seus entes. Eram, em sua grande maioria, localizados na zona periférica da cidade, em locais banhados por igarapés, o que, além de um toque poético, dava ao local certa privacidade a seus frequentadores. Na década 1970, esse tipo de bordel, com todos os seus trejeitos e feições, deixaria de existir, e em seu lugar surgiam os motéis, suplantando-os de forma avassaladora na prática de sexo pago no espaço citadino.

Assim, frente a este contexto, um dos motivos do presente trabalho foi exatamente a possibilidade de entendimento do que representavam os puteiros para a sociedade amazonense da época e, em especial o que eles significavam para um tipo social específico, que se consagrou em associação à eles, não apenas pela frequência com que os demandavam, mas, sobretudo, pela centralidade que aqueles espaços de prazer tinha nas suas vidas: os putanheiros. Buscamos também perceber e analisar como ambos - puteiros e putanheiros - eram representados no discurso jornalístico, ao longo de pelo menos duas décadas em que experimentaram o apogeu e a decadência.

Desde logo, o objeto central da pesquisa foi o puteiro, entendido aqui não só como o lugar onde se praticava o sexo pago, mas também como um ambiente em que se processavam relacionamentos afetivos e sociabilidades próprias, a provocar 
simbiose entre os desejos, as frustrações, as realizações e o lugar. 0 ser respirante que pulsava apressadamente nas noites de orgias era o mesmo que embalado pelos raios da manhã descansava languidamente a beira dos igarapés verdejantes de outrora. Suas células másters, putanheiros e prostitutas, após longas caminhadas, se encontravam no emaranhado de mesas, garçons, balcões, choferes de praça, quartos e amigos, produzindo risos, conversas, esperanças, amizades, e, claro, comércio de sexo. Tudo isso, como onipresente, gerava a vida cotidiana dos puteiros.

Paradoxalmente, parado num tempo constante e dinâmico, o lupanar da década sessenta do século XX, continuou a existir, ao menos nas lembranças de seus antigos membros, notadamente dos putanheiros de ontem, por eles acalentado como um espaço idílico, acessado nos momentos de nostalgia. A memória, seletiva e traiçoeira, neles borbulha verdades nem sempre acontecidas, mas tão desejadas, a ponto de a fantasia e o fato ocorrido se cristalizarem indistintamente, ao menos para aqueles que produziram tais lembranças.

A memória dos mais velhos ${ }^{7}$ se impôs em nossa pesquisa, como não podia deixar de ser. Se assim não fosse, como proceder diante de um tema tabu, em que o historiador se vê em apuros, perseguindo pistas fugidias por entre uma documentação tradicional, que, crivada de preceitos morais e religiosos, localiza essas práticas no perigoso espaço do submundo e do pecado, evitando deliberadamente referenciar tais espaços e seus personagens. ${ }^{8}$

Buscando socorro nos mais velhos, que viveram aquela época e que dominavam suas práticas, linguagens e símbolos, percebe-se que a lembrança dos entrevistados está eivada de fatos que deram vida aos puteiros. Alguns desses fatos, bizarros e inusitados, por vezes aconteceram com outros, mas foram presenciados pelos depoentes; outros fatos, bastantes comuns, tornavam normal sua realização. Essas reminiscências dialogam no tempo, não atuam só no passado, onde foram secamente vivenciadas, mas atuam também no presente, sendo continuamente reelaboradas. Resignificando o passado, conseguem assim

\footnotetext{
${ }^{7}$ BOSI, Ecléa. Memória \& sociedade: lembrança de velhos. São Paulo: T. A. Editor, 1979.

${ }^{8}$ Apenas a crônica policial, primando por uma visão estereotipada e assas preconceituosa, dará vazão e visibilidade a esse universo, embora em representações envoltas em preconceitos e visões depreciativas. Como se verá, os puteiros e seus personagens são por ela apresentados como espaços sombrios e transgressores; um cancro que, enquanto não fosse extirpado, continuaria a ameaçar, com sua simples existência, a parte sã da sociedade.
} 
perpetuar sua existência no presente. A maleabilidade dessa construção, nos impõe, todavia, a cautela, em especial porque, como nos lembra Pierre VidalNaquet,

Como historiador, sei, da mesma forma que todos os especialistas em minha área, que a memória não é a História, não porque a segunda suceda a primeira, por algum automatismo, mas porque o modo de seleção da História funciona de maneira diferente do modo de seleção da memória e do esquecimento. Entre Memória e História, pode haver tensão e até oposição. ${ }^{9}$

A escolha do tema lupanares e puteiros na sociedade manauara na década de 1960, da maneira que aqui se apresenta, veio ao encontro de duas vertentes historiográficas. A primeira, injetada por Edward Thompson, pode ser sintetizada pela opção a favor da adoção de uma "história vista a partir de baixo", tese esta desenvolvida e defendida pelo autor desde lançamento de A Formação da classe operária inglesa ${ }^{10}$ no início da década de 1960 e logo a seguir explicitada em $A s$ peculiaridades dos ingleses ${ }^{11}$, livro que ajudou a delinear sua forma de fazer história. Thompson, certamente não está sozinho. Antes, sintetiza a contribuição de toda uma geração de historiadores que envidou esforços em lançar um olhar peculiar à pessoas e objetos que estavam sub representados nos estudos históricos, sem grande visibilidade, deixados à parte dos chamados "grandes eventos", ou, por vezes, até mesmo esquecidos. 12

Sem essa importante inflexão historiográfica não teríamos a oportunidade de hoje elegermos os lupanares como objeto de estudo, sem cairmos no descrédito e no anedotário do vulgarismo historiográfico.

Partindo do tema maior do lazer e das práticas populares, se dirigirmos a perspectiva para a linha do trabalho, como acima citado, ou do gênero e da sexualidade, abordando-os numa vertente mais próxima da linha cultural, para o

\footnotetext{
${ }^{9}$ VIDAL-NAQUET, Pierre. Os Assassinos da Memória: "Um Eichmann de Papel” e outros ensaios sobre o revisionismo. Campinas, SP: Papirus, 1988, p. 10.

${ }^{10}$ THOMPSON, Edward Palmer. A Formação da Classe Operária Inglesa. 3 vols. Rio de Janeiro: Paz e Terra, 1987.

11 THOMPSON, Edward Palmer. "A História Vista de Baixo". In: As Peculiaridades dos Ingleses e outros artigos. Campinas, SP: Editora da UNICAMP, 2002, p. 185-201.

${ }^{12}$ Veja-se a importante contribuição da História Social Inglesa: HOBSBAMW, Eric. "A História de baixo para cima". In: Sobre História. São Paulo: Cia das Letras, 1998; KRANTZ, Frederick (Org.). A Outra História: Ideologia e protesto popular nos séculos XVII a XIX. Rio de Janeiro: Jorge Zahar Editor, 1990. Há, obviamente, exemplos dessa postura em outras vertentes historiográficas, mais próxima da produção oriunda da Escola dos Annales, como o do historiador polonês: GEREMEK, Bronislaw. Os filhos de Cain: vagabundos e miseráveis na literatura europeia, 1400-1700. São Paulo: Cia das Letras, 1995.
} 
estudo dos lupanares e puteiros teríamos necessariamente que utilizar "três noções que sustentaram a reflexão das ciências humanas e sociais: discurso, prática e representação", conforme defende Chartier, autor para quem, nesses casos, sugere ser sempre bom resgatar "a obra de Michel Foucault, a de Michel de Certeau e a de Louis Marin permitir precisar melhor seus contornos e definir com mais acuidade sua pertinência". 13

O conceito de representação quer seja empregado no sentido singular, quer seja relacionado às representações coletivas, às práticas sociais, tem permitido o alargamento da perspectiva cultural ao inserir outros princípios de diferenciação que não apenas o socioprofissional, fazendo de Chartier o expoente mais destacado dessa linha. Parte dessas perspectivas ajudou a delinear, em linhas gerais, nossa pesquisa, embora em alguns momentos e questões outras abordagens tenham sido utilizadas.

O caminho traçado na pesquisa seguiu, portanto, na confluência de tradições historiográficas paralelas e distintas - e em certas questões, até antagônicas $^{14}$ - com a consciência do cuidado necessário para não misturar em demasia e impropriamente, matérias que não se medem pela mesma escala. Antes, no envolvimento com essas tradições, tento salientar pontos e questões que me permitiram o diálogo do meu tema com a moderna historiografia, de cujos insights me puseram a pensar.

Já no prefácio da Formação da Classe Operária Inglesa, Thompson propõe um verdadeiro manifesto à revisão historiográfica da época, em busca de resgatar os excluídos da história.

Em meio a tantos outros, esses momentos da obra de Thompson, que versou não só acerca do movimento operário, também sobre crimes, protestos (individuais e coletivos) e o caráter tradicional e ativo da cultura popular, concorreram decisivamente para inspirar e dar forma e

${ }^{13}$ CHARTIER, Roger. À Beira da Falésia. A história entre certezas e inquietudes. Porto Alegre: Editora da Universidade, 2002, p. 18.

${ }^{14}$ Veja-se, por exemplo, a posição conflitante dos autores acerca do conceito de "Cultura Popular", valorizado por Thompson e recusado por Chartier: THOMPSON, Edward Palmer. Costumes em Comum: Estudos sobre a cultura popular tradicional. São Paulo: Cia das Letras, 2002; CHARTIER, Roger. Cultura Popular: Revisitando um conceito historiográfico. Estudos Históricos, vol. 8, no 16 (1995), 179-182. 
conteúdo a um modo diverso de se pensar, pesquisar, analisar e redigir a história, vista a partir de "baixo". ${ }^{15}$

Esse caráter tradicional e ativo da cultura popular foi perscrutado na pesquisa no momento da percepção de como se formou, cresceu e se extinguiu a cultura dos lupanares na década de sessenta do século passado. Num segundo momento, como as personagens que transitavam o universo dos bordéis tentavam comandar suas ações tanto dentro como fora da instituição lupanar, de maneira ativa e preponderante ante a reação da sociedade tradicional e provincial da cidade de Manaus daqueles idos. Tudo isso nos possibilitou visualizar o posicionamento dos frequentadores dos puteiros de uma maneira clara, sem os estereótipos da classe dominante, frequentemente expostos, produzidos e amplificados pelos periódicos matutinos.

Todavia, foi a eleição da forma e do conteúdo de fazer história - com a flexibilização necessária do modelo, e o cuidado para não olharmos a história pelas conformidades teóricas, posto que ao largo dela existam significados que, estando ocultos, podem esconder outras causas ou fenômenos - que deu a abordagem um sentido, para mim, revolucionário. Os modelos devem existir, os historiadores precisam deles, mas sua utilização deve ser feita com propriedade e serenidade para não ser dele escravo e,

Na melhor das hipóteses... devemos esperar por um delicado equilíbrio entre os procedimentos sintetizadores e os empíricos, numa disputa entre o modelo e a realidade. Essa é a tensão criadora no coração do progresso cognitivo. Sem essa dialética, o crescimento intelectual não acontece. 16

Essa preocupação com o modelo foi uma constante na nossa pesquisa, tanto quanto a compreensão e a necessidade do relacionamento com outras disciplinas irmãs afim de não cairmos no determinismo econômico, como foi à utilização da sociologia, da antropologia, e da geografia humana e territorial na pesquisa.

0 estudo de Thompson sobre classe e consciência de classe ${ }^{17}$, por mais improvável que pareça, auxiliou a pesquisa por dois motivos, sendo a primeira como alento sobre a necessidade que tivemos sobre o conhecimento dos

15 FORTES, Alexandre. Negro, Luigi e Fontes, Paulo. "Peculiaridade de E. P. Thompson". In: THOMPSON, Edward Palmer. As peculiaridades dos ingleses e outros artigos. Campinas, SP: Editora da UNICAMP, 2002, p. 24.

16 THOMPSON, Edward Palmer. As Peculiaridades dos Ingleses... Op. cit., p. 156.

17 Idem, p. 279. 
mecanismos como uma classe social se produz. No caso específico desta pesquisa, nos pôs a pensar como uma categoria ou instituição - a dos putanheiros -, se assim a Sociologia nos permitir denominar, produziu elementos de auto identificação, com consciência de si mesma e de como se contrapor às diretrizes dos que eram contra seus hábitos, costumes e preceitos.

Em segundo lugar, também emprestando do conceito de classe em um caso especifico, temos a visualização de que, embora sendo frequentadores de um mesmo lugar e participante de um modo de vida comum, são indivíduo de comportamento, rendas, status e profissões diferentes, que naquele ambiente se moldam em uma consciência de pertencimento que dão uma característica única ao grupo.

Outra obra de Thompson que foi objeto de estudo e, de certa forma, serviu de parâmetros para nossa dissertação, foi Costumes em comum, livro onde o autor deu nova interpretação a determinados costumes do século XVIII Inglês. Os artigos A economia moral da multidão e $A$ venda de esposas foram, para nós, os mais emblemáticos e discutidos do livro. Do primeiro, tirou-se a lição de que em toda mudança social passa pelo enfrentamento do costume tradicional com o novo que se instala, seguindo a "dialética repressão-protesto-concessão move-se no interior dessa retórica e dessas formas" ${ }^{18}$. Assim, pode-se perceber, neste estudo, que a troca dos lupanares pelos motéis ocorrida nos fins da década de sessenta e início da de setenta coexistiram de uma forma não muito harmoniosa, um lutando pela sua permanência, outro buscando seu lugar no sol.

Ressalta-se que não é só local da prática sexual que foi substituído, mas todo um ritual e suas representações; um costume que deixou de ser de uma maneira e passou a se desenvolver de outra forma. Ao mesmo tempo em que toda uma geração de jovens era gestada nos costumes dos motéis - mais individualista, segmentado, e com objetivo único voltado ao sexo - ancorada no surgimento de um novo boom econômico; outra geração se decompunha no definhamento dos puteiros, suspirando com certo saudosismo os ares provincianos de uma Manaus que não mais existia. Os costumes de ambos em espaços tão distintos, só se igualavam na realização do ato sexual, mas eram bem distantes e diferentes as práticas e as vivências dos frequentadores desses dois espaços.

18 THOMPSON, Edward Palmer. Costumes em Comum. Op. cit., p. 224. 
Todo costume esta inserido numa determinada época e só faz sentido dentro de um determinado contexto. Utilizando o conceito de cultura, tal como utilizado em Thompson, pode-se observar não só como um sistema de atitudes, valores e significados compartilhados, mas também as formas simbólicas (desempenho, artefatos) em que se acham incorporados:

É um conjunto de diferentes recursos, em que há sempre uma troca entre o escrito e o oral, o dominante e o dominado, a aldeia e a metrópole; é uma arena de elementos conflitivos, que somente sob uma pressão imperiosa - por exemplo, o nacionalismo, a consciência de classe ou a ortodoxia religiosa predominante - assume a forma de um sistema. E na verdade o próprio termo cultura, com sua invocação confortável de um consenso, pode distrair nossa atenção das contradições sociais e culturais, das fraturas e oposições dentro do conjunto. ${ }^{19}$

Entender esses valores compartilhados nos lupanares e puteiros foi um dos objetivos dessa pesquisa. Buscaram-se, em cada depoimento dos entrevistados, em cada notícia de jornal, os sentimentos transubstanciados em normas, reciprocidades, pertencimentos, a fim de poder compreender como estes eram experimentados com e em relação aos puteiros, na busca dos valores vivenciados numa dada época. Thompson nos lembra que:

\footnotetext{
Os valores não são apenas "pensados", nem "chamados"; são vividos e emergem no interior do mesmo vínculo com a vida material e as relações materiais em que surgem novas ideias. São as normas, regras, expectativas, etc.; necessárias e apreendidas (e apreendidas nos sentimentos), no habitus de viver; e apreendida, em primeiro lugar, na família, no trabalho e na comunidade imediata. Sem esse aprendizado a vida social não poderia ser mantida e cessaria toda a produção. ${ }^{20}$
}

Entre as principais contribuições de Thompson para as discussões teóricometodológicas está também a da "lógica histórica" como defesa da necessidade do dialogo permanente entre teoria e evidências no processo de construção do conhecimento $^{21}$. Entende Thompson, seguindo as explicações de Martins, que as teorias não podem ser utilizadas como um sistema fechado em que o fato social deva ser ajustado para se obter a pretensa veracidade; pelo contrário é necessário

19 THOMPSON, Edward Palmer. Costumes em comum. Op. cit., p. 17.

20 THOMPSON. E. P. A Miséria da Teoria ou um planetário de erros: uma crítica ao pensamento de Althusser. Rio de janeiro: Zahar, 1981, p. 194.

21 MARTINS, Suely Aparecida. "As contribuições teórico-metodológicas de E. P. Thompson: experiência e cultura". Revista Eletrônica dos Pós-Graduandos em Sociologia Política da UFSC. Vol.2 no 2 (4), ago-set/2006, p. 113-126. 
um diálogo entre conceito e evidências, hipóteses e pesquisas, daí sua definição sobre o método da lógica histórica:

\begin{abstract}
Por "lógica histórica" entendo um método de investigação adequado a matérias históricos, destinados, na medida do possível, atestar hipóteses quanto à estrutura, causação, etc., e a eliminar procedimentos autoconfirmadores ("instancias", "ilustração"). 0 discurso histórico, disciplinado da prova consiste, num diálogo entre conceito e evidências, um diálogo conduzido por hipóteses sucessivas, de um lado, e a pesquisa empírica, do outro. ${ }^{22}$
\end{abstract}

Esse método de investigação histórica permite que a pesquisa seja mais próxima da realidade ao possibilitar a seleção de uma ou de outra evidência; optar pela Micro-História, sem perder a visão global, mas não dependente desta; propor outras respostas a perguntas já respondidas, enfim torna a teoria mais maleável, posto que esta seja imprescindível. Mas é preciso entender que todos esses procedimentos não mudam o passado e nem a história até então escrita, mais pode chegar bem perto da possibilidade de verdade perseguida pelo historiador e entender que este conhecimento esta em constante desenvolvimento, portanto em mudança como bem salientou Thompson.

\footnotetext{
Adequados aos fenômenos que estão sempre em movimento, que evidenciam - mesmo num único momento - manifestações contraditórias, cujas evidências particulares só podem encontrar definição dentro de contextos particulares, e ainda, cujos termos gerais de análise (Isto é, as perguntas adequadas à interrogação das evidências) raramente com os movimentos do evento histórico assim como o objeto de investigação se modificam. Também se modificam as questões adequadas. 23
}

Com essa consciência, buscou-se pesquisar os puteiros dentro do tempo histórico atual, utilizando diversas ferramentas, inclusive pesquisas na internet e conhecimentos disponíveis em nossa década, com suas inovações e permanências. Assim, na abordagem da década estudada, percebeu-se que aquela realidade não só está em movimento, mas também em conflito e que as evidências, portanto, devem ser fixadas dentro de um contexto único, em consonância com as perguntas feitas aos entrevistados partícipes desta de pesquisa.

Ainda, seguindo os ditames de Thompson quanto à lógica histórica, procurou-se não ater-se somente à observação de fatos e fontes isolados, mas

22 THOMPSON, Edward Palmer. A Miséria da Teoria. Op. Cit., p. 49.

23 Idem, p. 48. 
perceber um conjunto de fatos com suas regularidades próprias, com o objetivo de identificar o que se repetia em cada evidência abordada (entrevista, jornais, memorialistas), ou seja, reconhecer as similitudes de comportamentos em diferentes contextos, para, enfim, contemplarmos as engrenagens que compunha a lógica comum do mundo dos puteiros da cidade de Manaus.

Essa abordagem às evidências, na pesquisa, foi feita não para entender a totalidade do que foi o puteiro, mais para responder ao que foi indagado, sem deixar de lembrar que o conhecimento histórico tem como característica ser sempre provisório e incompleto, principalmente diante de um objeto de estudo como esse, tão estigmatizado.

No entanto não deixa de possuir sua veracidade dentro de uma seletividade subjetiva, isto é, não abarcar sua totalidade e estar sempre limitado e definido pelas perguntas propostas pela pesquisa. Se assim não fossem, estaríamos advogando a utilização de teorias que não elegem as evidências como parte integrante do processo de conhecimento histórico ${ }^{24}$, pois,

Segue-se dessas preposições que a relação entre o conhecimento histórico e seu objeto não pode ser compreendida em quaisquer termos que suponham ser um deles função (inferência de revelação, abstração, atribuição ou "ilustração") do outro. A interrogação e a resposta são mutuamente determinantes, e a relação só pode ser compreendida como um diálogo. ${ }^{25}$

Diante de objeto de estudo colocado à margem pela historiografia então praticada, definitivamente não se teria a oportunidade de pesquisar o recorte histórico acerca dos puteiros dentro dos muros de uma universidade se não houvesse grande receptividade da obra de historiadores como Edward Thompson, muito embora tenhamos consciência que todo conhecimento é coletivo e cumulativo, temos que reconhecer sua originalidade.

Metodologicamente, encorada em Thompson, a pesquisa permitiu o preenchimento da criação de novos horizontes e levou à reflexão sobre o entendimento da realidade histórica como um processo; mostrou a importância da "experiência" e sua correlação com os aspectos culturais e por fim, a utilização da lógica histórica como método que determina ser imprescindível o diálogo permanente entre evidência e teorias para se atingir ao conhecimento.

24 THOMPSON, Edward Palmer. A Miséria da Teoria. Op. Cit., p. 38-49.

25 Idem, p. 50. 
No diálogo com outra vertente historiográfica que muito contribuiu na pesquisa está a abordagem de Roger Chartier, dentro do espectro da nova História Cultural $^{26}$. Esta abordagem aumentou a dimensão do termo cultura, discutiram-se os signos, as variações culturais, o "continuum" dentro das mudanças ocorridas, o imaginário social instituinte e as representações individuais e coletivas; enfim, as práticas culturais. Roger Chartier é, em certo sentido, o catalizador dessa linha de pensamento, sendo necessário reconhecer que sua obra é um aprofundado estudo sobre o pensamento historiográfico do fim do século XX e seus desafios atuais:

\begin{abstract}
"À beira da falésia". Era com essa imagem que Michel de Certeau caracterizava o trabalho de Michel Foucault. Ela parece me designar lucidamente todas as tentativas intelectuais que, como a nossa, colocam no centro de seu método as relações que mantêm os discursos e a práticas sociais. 0 empreendimento é difícil, instável, situado à beira do vazio. É sempre ameaçado pela tentação de apagar toda diferença entre lógica heterônomas, mas, no entanto, articuladas; as que organizam os enunciados e as que comandam os gestos e as condutas.

Seguir assim "à beira da falésia" também permite formular mais seguramente a constatação de crise ou, no mínimo, de incerteza frequentemente enunciada hoje em dia a cerca da história. 27
\end{abstract}

Depois de constatar a existência desse desafio, o autor faz um resumo do movimento historiográfico e metodológico dos historiadores nos últimos vinte anos, os quais geraram todo um modo de pensar e escrever história. Começa, então, a expor as noções que estavam sustentando nos últimos anos as reflexões dentro das ciências sociais: o discurso, a prática e a representação.

Nesse sentido, este entendimento sobre representações ${ }^{28}$ contribuiu para o desenvolvimento da pesquisa sobre os lupanares e os puteiros, primeiramente por nos permite utilizar uma nova leitura dos objetos,

\footnotetext{
${ }^{26}$ HUNT, Lynn (Org.). A Nova História Cultural. São Paulo: Martins Fontes, 1992: RIOUX, Jean-Pierre; SIRINELLI, Jean-François (Orgs.). Para uma História Cultural. Lisboa: Editorial Estampa, 1998.

27 CHARTIER, Roger. À Beira da Falésia. Op. cit., p. 7.

28 A noção de representação coletiva buscada em Durkheim onde podemos melhor perceber o conceito de mentalidade em três modelos de relação com o mundo. Primeiro o corte e classificação das configurações intelectuais múltiplas, segundo uma prática que visa reconhecer uma identidade social e por fim as formas institucionalizadas e objetivadas graças às quais representantes marcam de modo visível e perpetuado. Essa luta é assim exposta pelo autor "trabalhando sobre as lutas de representações, cujo objetivo é a ordenação da própria estrutura social, a História Cultural afasta-se sem dúvida de uma dependência demasiada estrita em relação a uma História Social fadada apenas ao estudo da luta econômica, mas também ao social, já que dedica as estratégias simbólicas". 0 termo representação atesta duas maneiras de um lado designa a manifestação de uma ausência, de outra é a exibição de uma presença. Na manifestação da ausência o que importa é as variações e não a clássica presença do ausente. CHARTIER, Roger. À Beira da Falésia. Op. cit., p. 73.
} 
Partir assim do objeto, das formas, dos códigos, e não dos grupos, leva a considerar que a história sociocultural viveu por tempo demais sobre uma concepção mutilada do social. Privilegiando apenas a classificação sócio-profissional, ela esqueceu que outros princípios de diferenciação, também plenamente sociais, podiam justificar, com mais pertinência, as variações culturais. É o caso das pertenças sexuais ou geracionais, as adesões religiosas, as tradições educativas, as solidariedade territoriais, os hábitos profissionais. 29

Assim, neste estudo, um primeiro desafio proposto foi o de compreender o universo de valores e as representações imbrincadas nos lupanares vividas e percebidas pela geração dos anos sessentas, que, como mencionado, denominavam aqueles espaços mais simplesmente de puteiro. Ou, ainda, compreender os processos de posse territorial simbólica, do "clima frio", ou do "lá pra dentro", significando com isso, entender qual era a sensação de pertencer àquele mundo marginal e excluído da sociedade, e demarcado como um território fortificado pelas representações de "zona imprópria" para a maioria da população, notadamente para as mulheres "direitas".

O segundo desafio seria o de coleta de dados com o cuidado de não "ignorar o processo pelo qual um texto, uma fórmula, uma norma fazem sentido para aquele que deles se apropriem ou recebem" 30 , e, portanto, na compreensão de um texto deve-se lembrar de que não há texto sem estratégia de escritura e sem as intenções do autor que a escreveu, inserido no seu tempo e no eu contexto social e a própria limitação do discurso.

Esse foi cuidado tido na pesquisa, não só quando no uso de fontes jornalísticas, mas também quando no momento de coleta das lembranças do memorialista, uma da época e eivada preconceitos, a outra mais distante no tempo e com tendência a suavizar o ambiente do puteiro.

Também foi necessário analisar, criteriosamente, as diferentes "categorias de signos" que permearam a pesquisa, por exemplo, enquanto os jornais, com todos os arquétipos da sociedade tradicional de então, qualificam esses locais de prática de sexo, de lupanares, rendez-vous, ou como antros de prostituição, os entrevistados os denominam pura e simplesmente de puteiros, quando estão entre seus pares, ou por metáforas, como "clima frio", perante estranhos. 0 objeto é o mesmo, mas as representações não o são. Enquanto o jornal passa uma imagem

${ }^{29}$ CHARTIER, Roger. À Beira da Falésia. Op. cit., p. 69. Grifo nosso.

${ }^{30}$ CHARTIER, Roger. "O Mundo Como Representação". Estudos Avançados, 11 (5), 1991, p. 181. 
claramente pejorativa do local, utilizando preconceitos consagrados no imaginário da sociedade, os frequentadores, por seu lado, o tomam como um local idílico. No jargão de Chartier, essa contradição pode ser explicada pela "existência de conversões regulando a relação dos signos com a coisa". ${ }^{31}$

\subsection{A BREve VIDA dos BordÉIS ClÁsSICOS.}

Não sendo um tema usual entre historiadores brasileiros e seguramente não sendo um tema já explorado pela historiografia regional amazonense, o entabulamento da pesquisa viu-se obrigado à recuperação de um conjunto de análises e discussões já bem avançadas no contexto historiográfico internacional.

É senso comum entre os estudiosos, quer sejam historiadores, médicossanitaristas, policiais, quer sejam romancistas, ideólogos ou moralistas, que no século XIX a prostituição mudou de status, sendo sua prática ampliada, remodelada e reprimida de modo sui generis. Nesse período a estrela do bordel acendeu e brilhou, só se apagando na década de trinta do século XX, não sem antes espalhar todo o seu glamour pelos quatros cantos do mundo, entre eles o Brasil. ${ }^{32}$

Naquele momento, mais que a França, a Inglaterra promovia uma mudança radical no modo de vida de sua população proporcionada pelo ascendente capitalismo comercial e no seio dessas mudanças a prostituição que passara a assumir uma nova e inédita essência, "uma essência racionalmente mercantil, no sentido preciso que a economia política dar ao termo" 33 , com isso inseria-se nos bordéis os princípios aplicados ao mundo capitalista burguês.

Necessário é que se faça um breve introito para que se percebam como alguns acontecimentos influenciaram essa mudança. A repressão do estado, notadamente das administrações das cidades e da polícia como órgãos legisladores e fiscalizadores, respectivamente, sempre atuaram no controle da prostituição e de seus locais de prática. No período prévio à Revolução Francesa existia em Paris o Inspetor Principal, a quem cabia mensalmente aposentar compulsoriamente

\footnotetext{
31 CHARTIER, Roger. À Beira da Falésia. Op. cit., p. 75.

32 ADLER, Laure. Os Bordéis Franceses. São Paulo: Cia das Letras. 1991, p. 11.

33 LIMA, Claudio de Araujo. Pequena História do Erotismo Ocidental: Amor e capitalismo. Rio de Janeiro, 1962, p. 12.
} 
trezentas prostitutas e vistoriar os bordéis onde se prostituíam aproximadamente trinta mil mulheres ${ }^{34}$. Segundo Lujo Berssermann, Luís XVI, tentando interditá-las em suas atividades, ganhou como inimigos trinta mil prostitutas, que participaram de forma contundente em diversos movimentos revolucionários. Assim, em outubro de 1789 pela Route de Versailles entre os oitos mil parisiense que marchavam rumo ao palácio, cerca de três mil mulheres vinham desse segmento. Ante as intenções proibitivas do monarca, "as participantes da demonstração... mais irritadas do que antes, caíram de assalto sobre a assembleia constituinte, iniciando-se então sobre os bancos e mesas do plenário verdadeira orgia em massa". Já em julho daquele ano, num encontro noturno entre prostitutas e um destacamento da cavalaria, essa foi forçada pelo desnudamento das prostitutas a debandarem para o lado revolucionário aos gritos de morte ao rei. 35

Em 1787, aos dezoito anos, pobre e solitário, o então segundo tenente da artilharia francesa, Napoleão Bonaparte. percorreu os arredores do Palais Royal a pretexto de fazer observações e ali entra em contato com uma jovem prostituta. Após confabulação praticam sexo venal ${ }^{36}$. Se a experiência serviu ou não para as mudanças radicais que o jovem corso poria em prática no seu consulado, não nos é possível saber, mas o certo é que após a poeira da revolução ter se dissipado Napoleão editaria seu código civil, onde descriminaliza muita das práticas sexuais, inclusive o bestialismo ${ }^{37}$, mas antes regulariza a prostituição com um estatuto próprio em 1802, sacramenta neste ato à criação do Regulamentarismo, que entre outras exigências torna obrigatório o exame médico periódico das prostitutas, o seu aquartelamento em zonas e um rígido controle sobre os bordéis, tudo com a intenção de zelar pela ordem pública ${ }^{38}$. Veremos mais adiante que esse regime Regulamentarista será contraposto pelo regime Abolicionista criado em meados do século XIX.

Assim, a despeito de terem sido tão fiscalizados e controlados pelas autoridades policiais e sanitárias, os bordéis prosperaram, entre outras coisas pelo

34 BASSERMANN, Lujo. História da Prostituição: Uma Interpretação cultural. Rio de Janeiro: Civilização Brasileira, 1968, p. 293.

${ }^{35}$ Idem.

${ }^{36}$ GORDON, Richard. A Assustadora História do Sexo. Rio de Janeiro: Ediouro, p. 57.

37 GREGERSEN, Edgar. Práticas Sexuais: A história da sexualidade humana. São Paulo: Livraria Roca, 1983, p. 21.

38 Conferência Nacional dos Bispos do Brasil. Comissão Episcopal de Pastoral. Prostituição desafios à sociedade e à igreja. São Paulo: Edições Paulinas, 1976, p. 64. 
aumento da oferta e da procura por algo que não é mais alvo da criminalização. Ao organizar-se uma atividade até então "imoral", esta passa a ser admitida e tende a crescer exponencialmente. ${ }^{39}$

Procurando inserir a discussão na história das mentalidades, embora reconhecendo suas dificuldades, Adler, para efeito didático, recorta o período de 1830 a 1930 como o período que vai do apogeu ao declínio dos bordéis na França e no resto do mundo, já em plena "Belle Époque". Assim, a década de 1880 é tomada como o começo da decadência. Com relação à essa decadência, não podemos deixar de dar importância à outra data, a de 13 de abril de 1945, quando foi editada a Lei Marthe-Richard que fechava por decreto todos os bordéis franceses e que serviu de exemplo para práticas coercivas similares em outros países.

Voltando aos seus primórdios, a consagração do bordel francês como local específico de libertinagem, de encontro de comerciantes do sexo, do glamour de seus aposentos, da degustação de vinhos e boas refeições, só se tornará visível em todo seu esplendor depois dos anos 1830. 40

Estudiosos do tema, Roy Porter e G. Rousseau, propuseram uma ilustrativa estratificação do meretrício ao longo dos séculos XVIII e XIX francês. De acordo com eles, o ícone do bordel clássico, a cortesã manteúda* nem sempre brilhava, portanto, em seus aposentos - de fato preferiam utilizar sua própria residência vinculando-se frequentemente a bordéis. Sendo bonitas, logo ganhavam muito dinheiro, sendo comumente mantida por um ou mais homens ricos e, desta forma, assim como surgiam, desapareciam fugazmente. Eram denominadas cocotes e tiveram seu apogeu nos anos de 1850, quando passaram a vestir-se como as filhas dos burgueses, frequentar teatros e finos restaurantes. Muitas eram, com efeito, viúvas ou mulheres abandonadas que só desejavam o necessário para manter seu modo de vida. Figuravam na época como não-classificadas, diferenciando-se, portanto, das desclassificadas, que tinham como representantes características, a mulher divorciada ou separada, ou ainda as que estavam envolvidas em escândalos. Como desclassificadas figuravam também as professoras estrangeiras ou as moças do interior, recém-chegada (e sem dinheiro) à Paris. Havia ainda, num

\footnotetext{
${ }^{39}$ Idem, p. 72.

40 PORTER, Roy e Rousseau, G. S. Submundo do Sexo no Iluminismo. Rio de Janeiro: Rocco, 1999, p. 15.

* Mulher sustentada pelo amante.
} 
estrato mais inferior, as arrivistas, procedentes dos teatros, cantoras de bailes populares, "mulheres do mundo", que só preocupavam com dia de hoje e quando envelheciam transformavam-se em degrafée, aquatique, quando depenadas pelos seus amantes, ou demir-castor, as que tentavam enganar a sociedade se fazendo passar por virtuosas. ${ }^{41}$

Quando a administração de sua profissão tornava-se cara, ou quando sua condição não mais permitia, passavam a ser agenciadas ou "posta em órbita por costureiras, alcoviteiras, mães mal-intencionadas, proxenetas da alta sociedade, espectadores profissionais do teatro de bulevar, tapeceiras em busca de lucros". ${ }^{42}$ Por dinheiro cediam seus corpos a um ou a muitos sem, contudo, explicitar seu amor, que só à poucos cediam sem nenhuma cobrança, a não ser a ânsia de se sentirem amadas. A estes últimos tornam-se fiéis, enquanto àqueles, apenas submissas.

\begin{abstract}
Dão a impressão de seduzir quando na verdade estão à venda, fazem os outros pagar e conseguem permanecer independente, mas mesmo a fortuna mais colossal não bastará a elas. 0 dinheiro corre em suas mãos. Ele não é capaz de fixá-las nem satisfazê-la, e elas nunca terão o suficiente. Rebelde em relação aos homens que as sustentam, continuam insaciáveis... A cortesã oferece ao amante o inesperado, o desequilíbrio. Guiada por seus instintos, a mulher pode se oferecer a quem quiser, quando quiser. ${ }^{43}$
\end{abstract}

A partir dos anos 1870 as cortesãs vão rareando no mundo prostituído de Paris - eram mais ou menos quarenta num universo de oitenta mil prostitutas -, denunciando a mudança nos costumes, onde capitalistas se precaviam e não mais se deixavam arruinar pela beleza efêmera delas. Assim, elas paulatinamente se esvaem, acomodando-se com a nova realidade: tornam-se menos indolentes e mas discretas e passam a prestar serviços nas casas de diversões. Assim, a moral burguesa pode se sentir salva e o cortesianato condenado à extinção, ou como sustenta Laure Adler, “a cortesã não existe mais, juntou-se ao exercito da prostituição". 44

Mas a prostituição na França não se resumia somente no cortesianato, concomitante e um pouco mais além, existiam diversos tipos de bordéis que

\footnotetext{
41 PORTER, Roy e Rousseau, G. S. Submundo do Sexo no Iluminismo. Op. cit., p. 23.

42 Idem, p. 27.

43 Idem, p. 31.

${ }^{44}$ ADLER, Laure. Os Bordéis Franceses, 1830 -1930. Op. cit., p. 40.
} 
satisfaziam a pequena burguesia e o operariado. Antes de classificarmos, necessário é que se tenha o conceito e entendimento do que era bordel naquele contexto. Para Bassermann o conceito fora pacificado enquanto forma genérica de "mansão de tolerância". Diz ele:

\begin{abstract}
No ano de 1840 contavam-se em Paris duzentos bordéis, para os quais, enfim, se havia encontrado a expressão Maison de tolérance e, como esses estabelecimentos de tolerância se destinassem à todos, bem depressa dinamitaram os velhos muros que a tradição e a lei tinham imposto à prostituição. ${ }^{45}$
\end{abstract}

Adler é mais específica e assim conceitua o bordel Francês:

\begin{abstract}
O bordel é uma casa, um espaço dirigido domesticamente pela proprietária, auxiliada por uma gerente, que, por sua vez, é auxiliada por empregadas. No interior da casa vivem pensionistas que aceitaram, por bem ou por mal, submeter-se ao regulamento. 0 bordel é um espaço fechado, tranquilizador para a polícia, angustiante para as meninas, prático para os clientes. O Bordel é um espaço vigiado: os médicos vêm fazer visitas sanitárias, a polícia dispõe de um registro, as moças estão sujeitas a um horário regular e a um ritmo de trabalho estafante, e os próprios clientes são examinados à entrada pela gerente, que analisa discretamente sua forma física e se informa sobre sua condição financeira. ${ }^{46}$
\end{abstract}

Para satisfazer a grande procura por sexo foram gerados diferentes tipos de bordéis, com diferentes níveis de conforto nas instalações, de preços das prostitutas e de poder aquisitivo dos clientes. Os burgueses frequentavam, quase que exclusivamente, as "mansões de tolerância", servidas pelas mais conceituadas prostitutas. Concentravam-se nos bairros nobres de Paris, Madeleine e Opera e eram verdadeiros hotéis do sexo, onde já na entrada o requinte se fazia sentir ao se transpor a dupla porta que isolava o barulho externo. Por seus vários corredores, ricamente decorados, o cliente era levado por uma funcionária ao gabinete da gerente onde lhes era informado sobre os serviços e seus preços, para logo após, em outro aposento, escolher sua prostituta, entre tantas ali dispostas, para só então se encaminhar ao quarto, geralmente exuberante em veludo ou exótico e temático. Preocupação constante com a discrição fazia com que o cliente que estivesse saindo não se encontrasse com o que estivesse entrando. Ainda de

45 BASSERMANN, Lujo. História da Prostituição. Op. cit., p. 307.

${ }^{46}$ ADLER, Laure. Os Bordéis Franceses. Op. cit., p. 44. 
acordo com as descrições de Adler, eram considerados pontos turísticos, como o Louvre ou Notre Dame. ${ }^{47}$

Os bordéis de segunda categoria não diferiam muito dos de primeira, a não ser no luxo e no requinte, mas a discrição era a mesma. Eram frequentados pelos pequenos burgueses e comerciantes remediados e em tudo procuravam imitar os de primeira categoria. Suas prostitutas ou estavam subindo ou descendo profissionalmente. Já a "casa de bairro" ou "casa de passe" eram, em relação às anteriores, barulhentas e ingênuas ao extremo. Na cidade se concentram em bairros afastados do centro, atraiam seus clientes, por vezes recorrendo ao exibicionismo das prostitutas que, após os ventos da revolução se exibiam nuas nas janelas. Com a repressão instaurada no período do consulado, estas práticas foram sendo combatidas e, assim, as prostitutas iam se vestindo mais e mais, até que, já no início do século XX, já se permitia mais janelas abertas.

Após adentrarem no recinto os clientes eram levadas ao salão onde se concentravam as prostitutas vestidas com diversos trajes: noivas, escolares, religiosas, vestais, babás ou de grande dama. Elas provinham de todas as partes, sendo muitas delas argelinas, negras (africanas), gregas, chinesas, alemãs e mesmo francesas de todas as regiões, perfazendo um total de mais ou menos vinte meninas por estabelecimento, onde, nesse tipo de bordel, faziam o serviço completo, oferecendo todo tipo de prática sexual requerida pelo cliente. Feita a escolha, recolhiam-se aos quartos, parcamente mobiliados por uma cama simples, geralmente rodeada de espelhos, e uma mesa, além de pequena sala de toalete, com água corrente para a higiene corporal. Com o tempo surgiram os quartos para voyeurs e quartos de torturas para sados-masoquistas. 48

Suas versões nas cidades do interior ficavam instaladas fora da cidade ou no seu limiar, geralmente rodeados de jardins e inseridos no bucólico mundo de silêncio e de isolamento. Jean Lorrain, grande putanheiro do começo do século XX, assim descreve a arquitetura de bordel do interior da França, no seu romance $L a$ Mansison Philibert: "Uma casa branca de dois andares comprimia-se sob um teto enorme, oferecendo no mínimo vinte janelas de fachada, era uma espécie de caserna deslocada no meio desse jardim". No primeiro andar fica o salão dotado de

\footnotetext{
47 ADLER, Laure. Os Bordéis Franceses. Op. cit., p. 57.

48 Idem, p. 58.
} 
bar, um piano e vastos divãs, os quartos no andar de cima parecem com quartos de hotéis chegando mesmo a parecer um quarto de donzela. Ali se pratica o sexo sem violência, domesticado tolerado pela vizinhança que as tens como casas públicas por alojarem mulheres que atendem homens a toda hora. São seus clientes homens honrados da cidade, comerciantes, rapazes, funcionários municipais, que todos os dias os frequentam para manterem encontros sociais, comerciais, de lazer, caracterizando um verdadeiro centro de sociabilidade tanto é a familiaridade que se estabelece entre seus membros ${ }^{49}$. A diferença entre o interior e capital nos é relatada por Adler nestes termos:

\begin{abstract}
Em Paris, o cliente com frequência é um desconhecido, que vem aliviar rapidamente um instinto, um contato-cólera como um estupro, para retornar a expressão de Maupassant; no interior, o cliente muitas vezes é um velho conhecido, quase amigo, e, nessas pequenas povoações onde as pessoas tagarelam muito e onde tudo se sabe, a prostituta torna-se, no correr dos anos, uma dama de companhia. Na capital, as moças esperam no salão em roupas mais reveladoras e convidam o cliente a beber champanhe... Com o auxilio da vertigem do álcool, os sentidos animalescos por essa cascata de luz, essa doçura envolvente, o cliente completamente estupefato segue a moça até o andar superior, onde encontra no sétimo céu sob o acolchoado. 50
\end{abstract}

Mas é o lupanar o local de maior barulho e de melhor animação dentro todos os tipos de bordéis existentes em Paris no início do século XX. Localizavamse em bairros distantes, geralmente em construção, nos portos, perto dos quartéis e suas mobílias eram simples, pronta para o amor rápido. Os quartos são apartados do local onde se bebiam e conversavam, sendo esses espaços frequentados por operários, soldados e marinheiros, misturados em mesas de mármores, onde conversavam, se tocavam e cantavam rodeados por prostitutas rudes e mantidas pelo álcool. Tudo isso dava ao bordel uma atmosfera de "volúpia de servidão para as moças e alucinações do desejo para os homens". 51

Quanto mais os preços cobrados caiam, mais o conforto das instalações recuava e as prostitutas careciam de beleza. 0 glamour ficava esquecido e a venda de carne era mais cruenta e mecânica. Antes de atingirmos o arquétipo do Monjol ${ }^{52}$, ainda veremos os tipos de bordel em que as prostitutas comiam e dormiam no em

\footnotetext{
${ }^{49}$ ADLER, Laure. Os Bordéis Franceses. Op. cit., p. 61-63.

50 Idem, p. 64.

51 Idem, p. 65.

52 Bordel de baixa qualidade e mal afamado, típico dos existentes à Rua Monjol, de onde derivaram seu nome,
} 
estabelecimento de dois pisos, sendo a parte de baixo destinada à algazarra da jogatina, dos fumantes, das bebedeiras e dos palavrões e, em cima, o espaço dos quartos com mobília e cheiro empobrecedor, só perdendo em feiura aos quartos do tipo do bordel de Monjol, arquétipo da decadência no gênero. Com efeito, quando se queria ferir moralmente uma mulher, a frase mais pesada era, segundo Adler: “- Vá para o Monjol”.

Viver num prostíbulo como este - os do Monjol - era estar sem nenhuma perspectiva de vida. Os bordéis desse tipo derivam de uma zona pobre da cidade de Paris - mais precisamente do bairro de Belleville, onde se localizava a Rua Monjol - que até hoje é chamada de "baixo meretrício". Estes bordéis sobreviveram até 1929, vindo então a ser desativados. Neles uma simples cortina separava a rua do botequim e o amor praticado ali se resumia a simples penetração. Se por um lado é satanizado pelos moralistas, por outro é endeusado pelos romancistas que viam nele a fascinação emaranhada no sexo, na miséria, na morte, na nudez e no amor.

Tais bordéis eram frequentados por funcionários da limpeza pública, trabalhadores de aterro, marinheiros de passagem, operários solteiros e assistidos por prostitutas bêbadas, carregadas de maquiagem e com roupas surradas, numa imagem que faz pensar que:

\footnotetext{
o inferno existe em Belleville nas ruas de Monjol e Aselin onde, entre miasmas, em quartos úmidos e sem cortinas, no alto de escadarias carcomidas, mulheres se ofereciam por preços irrisórios. Em baixo o café, ou melhor, a aparência de café: bancos, um aquecedor, um bar sujo, copos de vinho tinto, restos de lama, odor de petróleo, de cosméticos, de urina. ${ }^{53}$
}

Tendo como pano de fundo esses bordéis e as ruas da "Belle Époque", num espectro superior, as demi-mondaines, as "grandes cocottes", brilhavam e desfilavam no início do século XX, herdeiras diretas das cortesãs do século XIX. Na verdade só diferem das outras prostitutas por que se venderem a um número restrito de homens e por que possuíam, em geral, uma profissão paralela que lhe ajudavam a aparecer, como dançarinas, atrizes e cantoras, disfarçando a prostituição. ${ }^{54}$

\footnotetext{
53 ADLER, Laure. Os Bordéis Franceses. Op. cit., p. 70.

${ }^{54}$ LIMA, Cláudio de Araújo. Pequena História do Erotismo Ocidental. Op. cit., p. 100.
} 
Mas estas também eram poucas em relação ao grande contingente de prostitutas que povoavam a "Belle Époque". Em sua grande maioria frequentava os diversos tipos de bordéis, com idades variando entre vinte e um e vinte e cinco anos, sendo provenientes da classe operária ou da pequena burguesia. Foram, em sua grande maioria, desvirginadas por alguém de seu próprio meio e. assim, antes de irem aos bordéis já praticavam o sexo venal, embora frequentemente negassem:

\begin{abstract}
Sabem o que estão fazendo ali e, passada a emoção de se saberem trancadas longe do mundo, adotam sem resmungar muita a vida de pensionista. 0 bordel é em primeiro lugar um abrigo e um ganha-pão garantido. Por miséria, por abandono da família ou de um amante, por desânimo em relação a um trabalho mal renumerado elas acabam dando o passo decisivo. ${ }^{55}$
\end{abstract}

Para os moralistas de então as causa da prostituição eram a preguiça, a indolência, a infâmia, a vaidade e o desejo de brilhar. Para os médicos, higienistas e romancistas, as prostitutas eram duplamente marginalizadas, tanto no aspecto social quanto no sexual, mais todos, ao fim, concordavam que a miséria representava cada vez mais a causa ativa da prostituição.

Quanto aos clientes, eram de todas as classes sociais, predominando os empregados e os filhos das famílias ricas e, segundo estudo de Félix Regnault, feito em 1906 e citado por Adler, existiam quatro categorias de clientes; os libertinos, os tímidos e iniciantes, os desfavorecidos pela natureza e os homens casados com mulheres doentes. Os libertinos exigiam todo tipo de depravação, do voyeurismo ao beijo no ânus, passando pela masturbação labial, masoquismo e sadismo. Os rapazes da pequena e média burguesia iam ao bordel para perder a virgindade, muitas das vezes levados pelo pai. Estes, juntamente com os "feios", recorriam ao bordel para aliviar a tensão sexual. Não é à toa que, como nos lembra Adler, "a prostituta tem a função de aliviadora sexual, iniciadora e libertina". 56

O fim do século XIX traria ainda outra inovação: as casas de rendez-vous. Contextualizando o momento, Bessermann argumenta:

Às vésperas da Primeira Guerra Mundial, num estudo que veio a tornarse célebre, Parent-Duchatelet lamentou o lento morrer dos bordéis, pois a sociedade preferia a prostituição clandestina e as casas de rendez-vous por serem mais discretas: Para grande desgosto das autoridades, o

\footnotetext{
55 ADLER, Laure. Os Bordéis Franceses. Op. cit., p. 78.

56 Idem, p. 99.
} 
número de bordéis diminui de ano para ano e já não conseguem sequer assegurar a existência dos bordéis já anteriormente instalados. ${ }^{57}$

As casas de rendez-vous diferem das casas de tolerância por serem suas prostitutas externas, isto é, não dormirem no local de trabalho. Eram preferidas pela média e alta burguesia que no início do século XX se divertiam em duzentas dessas casas. Inicialmente aberta somente na parte da tarde, esses estabelecimentos eram calmos e pacíficos, tendo como funcionárias prostitutas registradas ou esposas de pequenos burgueses que vinham por vontade própria ou por necessidade de ganhos extras. 58

Mais outros locais de venda de sexo também frutificaram naquele início de século, com a liberação do comércio de bebida pelo estado surgia o proxenetismo de cabaré, onde suas garçonetes além de servirem bebidas se prostituíam nos quartos atrás do bar. Suas semelhantes eram as moças de cervejaria, oriundas na Exposição Universal de 1867, que embora servissem cervejas, faziam sexo em outro estabelecimento próximo, sendo suas proprietárias as antigas donas de casas de tolerância; Os cafés, tanto quanto os cabarés, viraram moda, e o surgimento do café-concerto foi seu ápice "Quanto aos burgueses, preferiam os cafés-concerto. Essa moda se desenvolveu a partir da década de 1880 e se espalhou por toda a província. Nenhuma aldeiazinha ficou sem seu café-concerto que contasse com umas cinco ou dez cantoras. As cantoras eram artistas, mas também prostitutas". ${ }^{59}$ No entanto, a grande maioria das prostitutas trabalhava na rua, nos pequenos cafés, nas estações ferroviárias, nos bulevares de dia e a noite em todos os lugares. Assim, como defende Adler, Paris seguia tranquila com "cada um em seu território. Para as classes populares, os cabarés, os barzinhos, os bailes. Para as classes burguesas, os restaurantes, as lojas de antiguidades, as casas de rendez-vous". 60

Mas o grande vírus da destruição dos bordéis já tinha atravessado o canal da mancha e, após seu período de incubação, é retomado de vigor a partir de 1877, com a chamada cruzada abolicionista ${ }^{61}$. Os bordéis percorreram as três primeiras décadas do século do XX, sob fogo cruzado, de um lado, perseguidos pelo fervor moralista contra os regularmentistas; por outro, a Grande Guerra que vitimou

\footnotetext{
57 BASSERMANN, Lujo. História da Prostituição. Op. cit., p. 323.

58 ADLER, Laure. Os Bordéis Franceses. Op. cit., p. 128.

59 Idem, p. 143.

${ }^{60}$ Idem, p. 143.

61 Idem, p. 183.
} 
milhares de homens e deixou outros tantos com o fastio desse tipo de diversão. Entremeado pela atípica atividade dos bordéis na retaguarda dos exércitos e o aumento do medo das doenças venéreas, a prostituição mais uma vez começa a ser atingida pela repressão e, não obstante uma sofrida sobrevida durante a segunda guerra, os bordéis são postos na ilegalidade por toda a Europa e, pasmem, por regimes democráticos:

Assim introduzido, pintado pelos grandes artistas da época, recordado pela literatura nobre através de Zola, Maupassant, Carco, Mac Orlan, Lenormand, bem como Werfel, Roth, Frank Harris, Pirandello e outros, decantado por Aristide Bruant, levado ao palco por Courteline, Feydeau e outros, o bordel passou à última fase de sua evolução. E, contudo, ninguém pressentia que seria essa a última, nem tão pouco se previa que a liberdade dos povos, através de governos republicanos e democráticos, acarretaria o fim de uma instituição que, mesmo sob os papas e príncipes da igreja, subsistira através dos séculos. ${ }^{62}$

Os países vencidos na primeira grande guerra foram os primeiros onde os abolicionistas venceram: Áustria, Hungria e Alemanha fecham os bordéis ainda antes da segunda grande guerra. Na França, os bordéis são atingidos pela crise econômica mundial e pelo domínio de seus estabelecimentos pelos nazistas durante a invasão alemã que, segundo fora alegado no congresso em 1946, os proprietários dos bordéis foram colaboracionistas com os inimigos. 0 debate entre abolicionistas e os defensores dos bordéis no parlamento Francês foi acirrado, mas prevaleceu a tese de Madame Marthe Richard e, em 13 de abril de 1946, como já mencionado, foi decidido o fechamento de todos os bordéis na França. 63

As consequências imediatas desse fechamento foram denunciadas pelo Senador Jean Durang: o aumento da sífilis, o crescimento do homossexualismo, o aumento das doenças venéreas entre as prostitutas e aperda de arrecadação dos bordéis, entre outras. A médio prazo, o problema era como controlar as milhares de prostitutas que passavam a trabalhar nas ruas e, a longo prazo, a prostituição estava preste a metamorfosear-se, deixando de ser sinônimo de bordel, de agrupamento de prostitutas sob a direção de uma madame, para se tornar uma prostituição descentralizada, onde quarenta prostitutas independentes se adaptavam mais rapidamente que um bordel. Isto comprovou mais uma vez que "podia-se fechar os bordéis, sim, podia-se até afugentar das ruas as prostitutas ou

62 BASSERMANN, Lujo. História da Prostituição. Op. cit., p. 316. Grifo nosso.

63 Idem, p. 342. 
enxotá-las para os subúrbios, mas a profissão específica, o comércio do sexo revelou-se inatacável, capaz de manter até seus postos avançados". 64

No aspecto sociocultural a primeira observação a ser notada foi à recuperação da prostituta que passa a ter controle de sua própria profissão, ganha liberdade de exibição tornar-se uma profissional do sexo e não mais uma perdida, a encarnação do mal. Paris, entretanto, continua a ser um gigantesco lupanar, o amor venal se industrializa e é reduzido ao ato sexual. Também na prostituição, tempo é dinheiro ${ }^{65}$. 0 sexo deixa de se exibir em bordéis, de ter uma visão pública para se esconder em pequenos ambientes, num comércio sexual intimista. de maneira que:

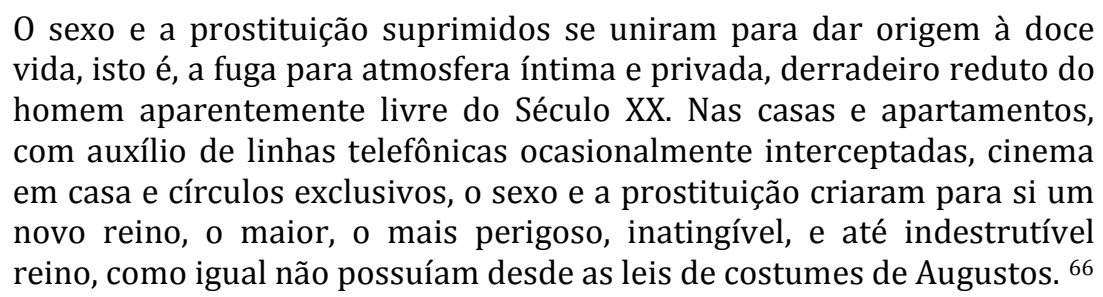

O individual se sobrepõe ao coletivo, como reza o capitalismo, embora muitas casas de rendez-vous tenham sobrevivido de forma precária ou totalmente descaracterizada apesar dos novos hábitos do amor venal.

Deste lado do Atlântico o bordel fechado é trazido no início da colonização inglesa e se espalha por todas as cidades. Na principal colônia inglesa, durante décadas a supremacia de cidade dos bordéis passou de mão em mão, por St Louis, Los Angeles, Nova Orleans - com seu famoso bairro Storyville - e, por fim, Nova York, cidade geradora e distribuidora de prostitutas para outras cidades. O Apogeu se deu entre 1890 e 1910 quando também, a exemplo de outras partes do globo fecham suas portas em bairros predeterminados, com a prostituição sobrevivendo em bordéis clandestinos e sofisticados. 67

A mudança do tipo de local, do estabelecimento, da atividade do sexo venal e com ela todas as estruturas que a sustentam, nas décadas de 50 e início de 60 é enfatizada neste comentário de Emmett Murphy:

64 BASSERMANN, Lujo. História da Prostituição. Op. cit., p. 348.

65 ADLER, Laure. Os Bordéis Franceses. Op. cit., p. 198.

66 BASSERMANN, Lujo. História da Prostituição. Op. cit., p. 352.

67 MURPHY, Emmett. História dos Grandes Bordéis do Mundo. Porto Alegre. Artes e Ofícios 1994. p. 223/243. 
Certamente, na Londres de hoje não há nada que se compare aos clubes privados da era eduardiana. A Lei das Ofensas na Via Pública, de 1958, forçou a maioria das mariposas a se recolherem, criando, na realidade, um clima semelhante ao de Nova York, com as pensões agrupando milhares de quartos de um único morador - na realidade bordéis individuais. 68

Essa macro mudança - dos bordéis de vivencia coletiva, fosse ele fechado, fosse ele no estilo casa de rendez-vous, para a venda de sexo em quartos individuais ou bordéis individuais - é que servirá de referência quando estivermos discutindo a passagem dos puteiros para os motéis na Manaus da década de 60 .

\subsection{Das Fontes, Aguadas E Lavadouros Às “Pensões de ARTistas” no Brasil.}

Na América portuguesa a prostituição, e os locais de prostituição chegaram pelas mãos dos europeus, como aconteceu com quase todos os povos contatados após as grandes navegações, embora nem todos desconhecessem a prostituição em suas culturas. Assim, excetuando-se as chamadas Altas Culturas - Maias, Aztecas e Incas, em que há registros de práticas similares à prostituição -, "a prostituição foi introduzida... pelos exploradores colonialistas e militares europeus, ou... surgiu pela ruptura da moralidade tradicional com a vinda dos europeus". 69

Convém lembrar, no caso brasileiro, o espanto e admiração dos portugueses ante a singeleza das índias quando do aporte da esquadra de Cabral e a facilidade, aliada a uma aparente inocência demonstrada pelos nativos diante do sexo ${ }^{70}$, facilitaram a fornicação sem a contrapartida do pagamento, anulando, desta forma, a principal característica da prostituição. Nos anos quinhentistas, excetuando as cartas de autoridades e de clérigos, pouco se colheu sobre a prostituição em si, mas algumas citações nos fazem crer que,

Talvez, uma das razões mais poderosas que, de certo modo, impedia o aparecimento ou o desenvolvimento da prostituição fosse a licenciosidade reinante. A facilidade com que as índias se entregavam ao homem branco, nesses primeiros tempos, era um óbice ao seu surgimento ou desenvolvimento.

${ }^{68}$ MURPHY, Emmett. História dos Grandes Bordéis do Mundo. Op. cit., p. 249.

${ }^{69}$ GREGERSEN, Edgar. Práticas Sexuais: A história da sexualidade humana. São Paulo: Livraria Roca, 1983, p. 146.

70 DEL PRIORE, Mary. Histórias íntimas: Sexualidade e erotismo na história do Brasil. São Paulo: Planeta do Brasil, 2011, p. 17. 
As mulheres, dizia Anchieta, "andam nuas e não sabem se negar a ninguém, mas, até elas mesmas cometem e importunam os homens jogando-se com eles nas redes, porque tem por honra dormir com os cristãos". 71

Os documentos da inquisição de Pernambuco e Bahia, estudados por Paulo Prado em Retrato do Brasil não dão, também, certeza sobre a prática de prostituição nos anos quinhentos na colônia portuguesa. Entretanto já se podia sentir sua aproximação por sinais constatados nas atas dos conselhos municipais. Na Câmara de São Paulo de 1572 a 1613 foram deliberadas quatro ações que tentava evitar a prática sexual nas duas fontes que serviam ao vilarejo. Em 1576, fora imposta uma multa de cinquenta réis e na reincidência cem réis que, não surtindo efeito, fez a câmara reiterar, em fevereiro e abril de 1590, desta feita aumentando a multa para quinhentos réis para qualquer individuo que fosse pego fazendo sexo com as índias nas fontes, sendo que a pena se concretizasse bastava uma testemunha de cor branca. No início do século seguinte as multas aumentam para quinze mil réis e foi proibida a ida às fontes por menores de quinze anos e, "a partir de então, desapareceram por um período mais ou menos longo, as referências aos atos imorais praticados junto às fontes, aguadas e lavadouro da velha São Paulo". 72

As fontes, aguadas e lavadouros não foram os únicos locais onde se praticava o sexo na colônia. Nas praias, nos campos, e nos matos também se mantinham relações sexuais, sendo que o local menos utilizado era precisamente a casa e isto devido a pouca privacidade que reinava nas casas de então, sem portas internas, nem fechaduras, como bem salienta Mary Del Priore:

\begin{abstract}
$\mathrm{Na}$ alcova podia haver uma cama coberta por mosquiteiro, colchão rijo, travesseiros redondos e chumaços, e excelentes lençóis. Elemento de ostentação nas casas ricas, a cama traduzia um nível de vida: a conquista do tempo e da liberdade, mas para suas intimidades, os casais sentiam-se mais à vontade "pelos matos", nas praias, nos campos, na relva. Longe dos olhos e ouvidos dos outros. ${ }^{73}$
\end{abstract}

Não podemos, neste período, usar o termo prostíbulo na acepção da palavra que aqui buscamos, qual seja, local onde se reúnem prostitutas a espera de clientes para a venda e consumo de sexo, mais não quer dizer que espaços assim não

\footnotetext{
${ }^{71}$ FONSECA, Guido. História da Prostituição em São Paulo. São Paulo: Resenha Universitária, 1982, p. 14.

72 Idem, p. 17.

73 DEL PRIORE, Mary. Histórias íntimas. Op. cit., p. 24.
} 
poderiam ter existido. Contudo, a prostituição no Brasil criou asas na segunda década do século XVII, já que, de forma indireta, é constatada a sua presença, com a nomeação de quadrilheiros, em 1620, em São Paulo, e 1626, no Rio de Janeiro, para combater, entre outras coisas, alcoviteiras ou mulheres que estejam infamadas, segundo as Ordenações Filipinas ${ }^{74}$ e, em 1641, a Câmara paulista expulsou as que seriam as duas primeiras prostitutas registradas na história brasileira: Mariana Lopes e Joana Pereira. Outra evidência da prostituição em São Paulo é a fundação em 1685 da casa de "Recolhimento de Santa Teresa". Não obstante servir de passagem de prostitutas brancas por São Paulo rumo às minas e Cuiabá, e sem dinheiro para adquirir as negras os paulistas usaram como prostitutas as índias escravizadas. ${ }^{75}$

Mesmo em cidades onde as escravas negras eram utilizadas como prostitutas, as índias não deixaram de servir à fornicação, embora, ao que parece, fossem minorias. Gilberto Freyre, ao demonstrar o papel sexual desempenhado pelas negras, assim reproduziu o ditado popular: "branca para casar, mulata para foder e negra para trabalhar". Del Priore assim esclarece:

\begin{abstract}
Degradadas e desejadas ao mesmo tempo, as negras seriam o mesmo que prostitutas, no imaginário de nossos colonos: mulheres "aptas à fornicação", em troca de algum pagamento. E na falta de mulheres brancas, fossem para casar ou fornicar, caberia mesmo às mulheres de cor o papel de meretrizes de ofício ou amantes solteiras, em toda a história da colonização. Nos séculos seguintes, à degradação das índias como objeto sexual dos lusos somou-se a das mulatas, das africanas, das ladinas e das caboclas. Mais desonrada que as "solteiras do Reino", nome que se dava às prostitutas portuguesas, pois aquelas mulheres, além de putas, eram negras. 76
\end{abstract}

Assim adentramos no século XVIII para só então termos notícias da existência das primeiras casas de prostituição em São Paulo. Guido Fonseca, citando a Ata de 04 de novembro de 1721 da Câmara paulista, confirma que existiam diversas "casas de mulheres" num local que deveria ser instalado um açougue e acrescenta: “é significativo, porém, que a Ata da Câmara tenha se expressado no plural indicado que o meretrício alcançara já certo desenvolvimento, com vários lupanares funcionando" 77. E isto é indicativo de uma

\footnotetext{
${ }^{74}$ FONSECA, Guido. História da Prostituição em São Paulo. Op. cit., p. 21.

75 Idem, p. 24-25.

76 DEL PRIORE, Mary. Histórias íntimas. Op. cit., p. 46.

77 FONSECA, Guido. História da Prostituição em São Paulo. Op. cit., p. 35.
} 
prostituição com algum grau de organização. Por outro lado, os garimpos de Cuiabá receberam inúmeras prostitutas, que passaram necessariamente por São Paulo, a ponto de seus prostíbulos funcionarem de dia e de noite.

É mister que se faça um registro sobre as prostitutas do final do período da America portuguesa. Pouco ou nenhum emprego ou ocupação tinham as mulheres na pauliceia, sendo oficialmente registradas em 1822, 92 costureiras e 48 rendeiras, numero muito superior às encomendas por elas recebidas, o que sugeria serem elas, de fato, prostitutas. 0 Grande número de mulheres, de todas as cores, disputando homens nas ruas intrigou o viajante Daint-Hilaire, a ponto de afirmar que em lugar algum na terra vira tão grande quantidade de mulheres públicas na rua à noite como em São Paulo. 78

A chegada da corte portuguesa no Brasil, mas precisamente no Rio de Janeiro, trouxe não só o poder político e um grande contingente de pessoas que estavam inseridas nas inovações da Europa, mas também propiciou condições para que a expansão da lavoura cafeeira substituísse as plantações de cana-de-açúcar. Aliada a essas condições, a efetivação da abertura dos portos tornaram o Rio de Janeiro um centro comercial e exportador do Brasil. De imediato, houve um grande crescimento populacional na capital, passando de 60.000 habitantes quando da chegada da Família Real, para 116.444 habitantes no início do Império, e isto se deu... "sobretudo, devido à abertura do país à imigração europeia e a introdução sempre crescente de trabalhadores escravos, empregado nas diversas atividades econômicas e domésticas". 79

A prostituição sempre existiu no Rio de Janeiro conforme relato de autoridades e cronistas, sendo que no final do século XVIII estimativas davam como existentes 255 mulheres de janela, como eram chamadas as prostitutas de então. Em 1822 o viajante Jacques Arago relata a grande quantidade de mulheres públicas em todas as ruas da cidade. Na primeira metade do século coexistiam três tipos de prostitutas pela sua origem: as solteiras do reino; as brasileiras (aqui estão as índias, cafuzas, e negras libertas) e as escravas, estas últimas configurando uma prostituição atípica, ou como chamam alguns, de prostituição clandestina 80 .

\footnotetext{
78 FONSECA, Guido. História da Prostituição em São Paulo. Op. cit., p. 64.

79 SOARES, Luiz Carlos. Rameiras, Ilhoa, Polacas: A prostituição no Rio de Janeiro do século XIX. . São Paulo: Ática, 1992, p. 9.

80 Idem, p. 62-67.
} 
Essa atipicidade estaria relacionada com a posse do objeto a ser vendido, já que, no caso concreto, o corpo da escrava é um patrimônio do seu dono e, portanto, a classificação clássica do conceito de prostituição ficaria assim prejudicada.

Os locais onde se praticavam sexo venal ainda por volta de 1844 eram as fontes e chafariz na cidade de São Paulo, embora, como sustente Guido Fonseca, "sobre os lupanares da Capital, nesses tempos, praticamente nada se sabe. Uma das poucas referências nos foi deixada por Fagundes Varella em seu poema 'A terra da promissão', [onde] descreve ligeiramente seus habituais clientes" 81. Outra referência à bordel, desta vez à um prostíbulo de negras escravas, aparece na obra de Bernardo Guimarães "Rosaura, a enjeitada", onde se detalha em minúcias o local e o ambiente reinante no recinto. Embora seja um romance, há forte indícios de que ele de fato existiu. 82

$\mathrm{Na}$ cidade do Rio de janeiro, em 1845, existiam seis "alcouces ou conventilhos ou colégios" onde sete ou mais prostitutas exerciam seu ofício. Mas "assim, o bordel, meta maior das tentativas de higienização do sexo e da prostituição surgidas no Brasil depois de 1840, deveria ser o local de exercício de uma função do corpo, não local de paixão e disseminação de vícios". 83

No reinado de D. Pedro II, principalmente nas suas três primeiras décadas, o Rio de Janeiro imitava em tudo a cidade de Paris; lia-se Byron, fundavam-se sociedades, elegiam-se os pés e as mãos pequenas como fetiche, etc. Tentavam, enfim, viver como parisienses no paraíso tropical. 84

Esporadicamente chegavam ao Rio de Janeiro algumas prostitutas vindas da Europa, comumente de Portugal, mas foi a partir de 1840 que o volume de portuguesas vindas do continente e ilhoas de Açores e Madeira cresceu, com a intenção de trabalhar no comércio ou em serviços domésticos as estrangeiras acabavam, em boa medida, indo parar na prostituição. Em 1872, num trabalho de Ferraz de Macedo, citado por Soares, havia em quatro freguesias do Rio de Janeiro 1.171 meretrizes, onde 818 eram brasileiras, 271 portuguesas e apenas 82 de outros países. ${ }^{85}$ As nativas eram maioria.

\footnotetext{
81 FONSECA, Guido. História da Prostituição em São Paulo. Op. cit., p. 89.

82 Idem, p. 125.

83 SOARES, Luiz Carlos. Rameiras, Ilhoa, Polacas. Op. cit., p. 105.

${ }^{84}$ DEL PRIORE, Mary. Histórias íntimas. Op. cit., p. 71.

85 SOARES, Luiz Carlos. Rameiras, Ilhoa, Polacas. Op. cit., p. 50.
} 
As famosas polacas aportaram na baia da Guanabara pela primeira vez em 1867 e, das 104 que desembarcaram, 67 ficaram na corte, e o resto seguiu para a Argentina. Daquele ano até 1900, entraram mais de 10.000 prostitutas estrangeiras no Brasil pelo Rio de Janeiro, ficando em média três anos na cidade, para dali saírem em direção à São Paulo, Santos, Argentina ou em retorno a seus países de origem. ${ }^{86}$

$\mathrm{Na}$ época, as mais cobiçadas pelos coronéis eram as francesas, portadoras, além dos predicados sexuais, símbolos de civilização ${ }^{87}$. Não foram poucos os filhos da classe dominante que se iniciaram sexualmente com elas, sendo no Brasil chamadas de cocotes, assim como em Paris. Sobre elas escreveu Soares:

\begin{abstract}
Sobre a prostituição de luxo, ou de "alta categoria", aquela existente em Botafogo e na Rua do Catete e suas transversais, pode-se dizer que ela era exercida pelas francesas ou mulheres brasileiras brancas: as "cocotes", como eram chamadas as prostitutas cortesãs na segunda metade do século passado. As prostitutas francesas constituíram-se na fixação daqueles contemporâneos que frequentavam o Catete e o Botafogo. Dizia-se, na época, que muita das francesas durante o dia exercia a atividade de modista na Rua do Ouvidor (a rua do finíssimo comércio da cidade).

Além das modistas, algumas cantoras e atrizes francesas, ao mesmo tempo em que eram assediadas pelos homens ricos e de boa posição que frequentavam os teatros e cafés da moda, eram denunciados pelos guardiões da moralidade da época e pelas esposas desassossegadas e temerosas de perderem seus maridos. ${ }^{88}$
\end{abstract}

Na cidade de São Paulo, antes do início de seu desenvolvimento, por volta de 1875, e antes da chegada das levas das prostitutas estrangeiras, "o meretrício, antes das grandes levas de imigrantes, de um modo geral, era pacato. As mulheres públicas salvo algumas exceções exercia seu comércio sem escândalos, ofensas e desordens". 89

No final do século XIX o núcleo da prostituição concentrava-se nas ruas do Quartel, Senador Feijó, da Esperança e nos becos do Trem e dos Mosquitos. A ralé se comprimia nos três últimos. Outro local de "depravação" foi a Rua São José, hoje Líbero Badaró. Enquanto isso, "por essa época, o meretrício mais elegante e recatado podia ser encontrado nos inícios da Rua São João e Largo do Paissandu. 0

\footnotetext{
${ }^{86}$ SOARES, Luiz Carlos. Rameiras, Ilhoa, Polacas. Op. cit., p. 54.

${ }^{87}$ Sobre isso, diz Lená Menezes: "As 'estrangeiras' tornaram-se símbolos da modernidade; frequentá-las , sinal de refinamento". MENEZES, Lená Medeiros de. Os estrangeiros e o comércio do corpo nas ruas do Rio de Janeiro (1890-1930). Rio de Janeiro: Arquivo Nacional, 1992, p. 103.

88 Idem, p. 55.

89 Idem, p. 130.
} 
pessoal endinheirado ali se divertia a valer e o champanha era a bebida obrigatória. Numa demonstração de riqueza muitos acendiam os charutos com uma cédula 500 mil reis, em chama". 90

Já em 1910, o baixo meretrício, frequentado por homens de menor posse, jovens estudantes, boêmios e servidos por meretrizes pretas e mulatas, perseguidas pela policia, se move do centro para locais mais distantes, concentrando-se entre as ruas Senador Feijó, Riachuelo, Ladeira São Francisco até os Piques, ponto das prostitutas negras ${ }^{91}$. Fonseca amplia essa concentração incluindo a Rua Timbiras, Amador Bueno e Ipiranga, e informa que assim permaneceu até 1934 . Naquele ano, diz ele a polícia "tinha registrado nada menos que 283 casas de mulheres espalhadas por uma centena de ruas, 248 eram chamadas de pensões abertas e as 35 restantes estavam catalogadas como rendezvous fechado". 92

Mas nem só de baixo meretrício a prostituição vivia em São Paulo nas primeiras décadas do século XX, já que ali estavam presente também às cortesãs de luxo que moravam em mansões e palacetes próprios, geralmente construídos por algum coronel e localizados em áreas nobres como a Avenida Paulista. Abaixo destas havia a prostituta que possuía sua mansão ou alugava uma onde recebia seus fregueses, mas sem o vínculo da exclusividade com qualquer um deles, ou com qualquer cafetina. Abaixo dessas, vinham as que viviam nas "pensões de artistas" e que estavam submissas a uma cafetina, além das que habitavam os hotéis e "pensões chiques" como os famosos Grand Hotel e Hotel dos Estrangeiros; por fim, existiam os cafés-concertos, com suas exibições de gêneros artísticos variado da dança do ventre à luta romana, onde tudo era exibido, o que transformava o café num misto de teatro, circo e bordel. Mas ainda na década de 1920 estes cedem lugar ao cabaret ou cabarés na preferência do publico. Margareth Rago descreveu essa mudança:

No ano de 1920, o café-concerto cedia espaço para os cabarés, desaparecendo as exibições circenses e variadas que constituíam o gosto do público na passagem do século. Progressivamente, os cabarés elegantes se refinavam enquanto ambientes masculinos do prazer, onde

\footnotetext{
90 SOARES, Luiz Carlos. Rameiras, Ilhoa, Polacas. Op. cit., p. 153.

91 RAGO, Margareth. Os Prazeres da Noite: prostituição e códigos da sexualidade feminina em São Paulo (1890-1930). Rio de Janeiro: Paz e Terra, 1991, p. 84.

92 FONSECA, Guido. História da Prostituição em São Paulo. Op. cit., p. 157.
} 
se podia dançar acompanhado pelas cocotes, ao som de valsas bem tocadas, ou onde homens jogavam pôquer e podiam consumir éter, cocaína e demais drogas em moda. Mistura de bar, bordel e restaurante, o cabaré de luxo encantava os boêmios da cidade como ponto sensual de convergência de fluxos desejantes. 93

Ver-se, pois, que os cafés-concerto, a princípio, e os cabarés, por derradeiro, tinham como principal atração a prostituta, que ao mesmo tempo em que eram disputadas por cafetinas donas de conventilhos, disputavam também os desejos de algum milionário. Os mais conhecidos são o Cassino Paulista, que apresentava nudez artística e o Moulin Rouge, com artistas internacionais, além do Cassino dos Médicos.

A característica geral do lenocínio no período compreendido entre 1840 e 1958, no Brasil, pode ser entendida como o embate entre o regulamentarismo, que, como vimos no caso francês, pregava a intervenção estatal no controle das prostitutas, confinando-as em bordéis e fichando-as na policia, como mecanismos de defesa da saúde pública; o abolicionismo, que pregava a eliminação de qualquer controle do estado sobre a prostituta e o proibicionismo, que considerava a prostituição um delito ${ }^{94}$. As primeiras ideias de como controlar a prostituição na cidade do Rio de Janeiro foram expostas pelos médicos nos anos 1840, mas "nenhuma medida de repressão à expansão do meretrício e de controle das mulheres públicas foi tomada até os anos 1870, quando se deu a adoção de algumas medidas pelo chefe de Policia Ludgero Gonçalves da Silva" 95. Isso não quer dizer que uma ou outra medida não foi ventilada e até votada na câmara, mas efetivamente seus impactos só se fazem sentir após 1870.

Para alguns estudiosos, não houve no Brasil o regime regulamentarista após a implantação da República e a prostituta jamais se submeteu ao regime de bordel fechado ou a exames forçados. Quanto a isso, Pereira defende que

\footnotetext{
Não obstante, na prática, adotou-se sempre um regulamentarismo mitigado. Toleravam-se as casas de prostituição, quer do tipo aberto, em ruas quentes, como existiam, no Rio, na Lapa, e ainda existem, modificadas, no Mangue, quer do 'convertilho', de portas fechadas, onde as mulheres, sem residir, vão realizar encontros por algumas horas, a troco de pagamento. 96
}

\footnotetext{
93 RAGO, Margareth. Os Prazeres da Noite. Op. cit., p. 99.

94 PEREIRA, Armando. Prostituição: Uma Visão Global. Rio de Janeiro: Pallas, 1976, p. 8.

95 SOARES, Luiz Carlos. Rameiras, Ilhoa, Polacas. Op. cit., p. 94.

96 PEREIRA, Armando. Prostituição: Uma Visão Global. Rio de Janeiro: Pallas, 1976, p. 40.
} 
Para outros, implicitamente, está comprovado o regulamentarismo, embora com característica nacional. Por exemplo, Lucius de Mello, na biografia romanceada "Eny e o grande bordel brasileiro", nos mostra o registro policial da prostituta, detalha a visita e o exame médico ${ }^{97}$. Mas para serem os clássicos requisitos, faltaria apenas a reclusão total das prostitutas nos bordéis, o que a rigor no Brasil da época nunca aconteceu.

No Rio de Janeiro o Mangue possuía duzentas pensões na década de 1930, onde se praticava a prostituição mais a granel do que em "convertilhos", muito embora tenha-se registro desse tipo de prostituição até 1964. Em 1945, após anos de liberação, volta a existir o regime de tolerância ante a invasão dos bairros da Tijuca e Copacabana entre outros adjacentes ao Mangue e que perturbavam a paz pública. 98

Em 1959, o bordel fechado, "convertilho" ou pensão alegre, recebe mais uma denominação, como se pode ver no trabalho de pesquisa de Maria Luiza Alves sobre a prostituição no Rio de Janeiro. A autora usa a designação de "Meretrício Localizado" que Barruel Lagenest assim sintetizou:

\begin{abstract}
Chamaremos de meretrícia localizada, àquelas que frequentam um determinado bordel de uma determinada zona de prostituição, devendo a dona da casa ou gerente, obediência e porcentagem nos seus ganhos. 0 número de meretrizes em cada um desses bordéis é, em geral, determinado, só trabalhando lá quem a responsável permitir e dentro de um horário pré-estabelecido. ${ }^{99}$
\end{abstract}

Esse tipo meretrício ficava localizado no Mangue, muito embora sua espécie elevada tivesse como endereço algumas ruas de Copacabana e da Lapa. Eram controlados pela polícia, seja quanto aos registros das prostitutas, seja quanto ao funcionamento do bordel. Contrapondo-se a ele, existiria o Meretrício Flutuante, que englobaria as prostitutas que praticavam o "trottoir" nos vários pontos do Rio de Janeiro e, por fim o Meretrício Clandestino, que é caracterizado por prostitutas intelectualizadas, que não fazem da prostituição um meio de vida, e sim um caminho para o luxo, o conforto e a fama. 100

\footnotetext{
${ }_{97}$ MELLO, Lucius de. Eny e o Grande Bordel Brasileiro. Rio de Janeiro: Objetiva, 2002, p. 242.

98 PEREIRA, Armando. Prostituição: Uma Visão Global. Op. cit., p. 66.

${ }^{99}$ LAGENEST, Barruel D. H. Lenocínio e prostituição no Brasil. Rio de Janeiro: Agir, 1960, p. 24.

100 Idem, p. 33.
} 
Em São Paulo o bordel fechado já chamado de "convertilho" e de "pensões de mulheres", na pesquisa da Dr. Elvira Aguiar Borges Furlan - também utilizada por Lagenest - passa a ser denominada "casa de tolerância" e "rendez-vous". Na cidade existia cerca de 140 estabelecimentos desse tipo, com 1.384 prostitutas e seu funcionamento era autorizado pela polícia que, além controlar o horário e o local, também geria o mulherio a ele adstrito: "As casas de tolerâncias eram abertas mediante autorização e vigilância da administração pública, e as mulheres que nelas iam morar, eram inscritas em registros especial da polícia - o registro das meretrizes". 101

Os rendez-vous de Belo Horizonte traziam similitudes com os de São Paulo e Rio de janeiro, existindo na zona boêmia o baixo meretrício, localizados no centro, nos bairros da Floresta e Lagoinha e próximo à estação Ferroviária e rodoviária. Tinham como aspectos casa, hotel ou a pensão onde as prostitutas pagavam diárias gozando de plena liberdade. 0 alto meretrício era "constituído por rendez-vous espalhados por toda a cidade, e sustentados quase exclusivamente por clientes de alta categoria. São feitos em casas especialmente alugadas para esse fim e que, atualmente ultrapassam 300" 102. Ao contrário do bordel fechado, aqui o produto do aluguel dos quartos e a venda de bebidas eram as principais fontes de receita das proprietárias. Quanto às prostitutas, eram bonitas e com nível intelectual razoável, gastando tudo o que ganhavam com joias, roupas e hotéis caros. Era a fina flor da prostituição.

Nesse primeiro quartel do século XX, é necessário que se dê destaque, mesmo que an passant, a dois elementos constituintes do mundo prostitucional no Brasil daquele período, sendo o primeiro o fato de que, para não deixar de acompanhar as novidades europeias, desfilaram prostitutas que ficaram na história e no imaginário dos homens de meados do século XX não só por serem bonitas - embora principalmente por isso! -, mas por terem vidas intensas, cinematográficas, algumas delas viraram cafetinas famosas. Em segundo lugar, a forte incursão no território brasileiro do tráfico de mulheres brancas, oriundo da Europa e direcionado ao Brasil e à Argentina através de sociedades como a judia

${ }^{101}$ LAGENEST, Barruel D. H. Lenocínio e prostituição no Brasil. Rio de Janeiro: Agir, 1960, p. 50.

102 Idem, p. 74. 
Zwi Migdal, que congregava rufiões portenhos ${ }^{103}$, responsáveis pela introdução de diversas "polacas" e suas colegas livres. 104

A primeira grande cortesã que se transformou em cafetina foi Mme. Sanches, retratada no romance de Hilário Tácito como Mme Pommery ${ }^{105}$. Profissional surgida do baixo meretrício, a lógica de seu aparecimento liga-se à necessidade que a cidade tinha de se modernizar e restituir o bordel de alta prostituição em detrimento aos lupanares de então, que serviam cerveja e cobravam taxa de hospedagem ínfima, enquanto a orquestra tocava maxixes ${ }^{106}$. Abrindo a pensão de artista "Palácio de Cristal", Mme. Sanches contratou belas mulheres, triplicou o valor do champanha e, para o romancista, assim ficou rica, mas a imprensa desconfiava que ela traficasse cocaína e até denunciasse seus concorrentes. "Em breve, transformava-se na mais rica cafetina de S. Paulo. Proprietária de prédios na São João e acionista de companhias, gozava de grande prestígio entre os políticos, jornalistas e milionários da época" 107. Após enriquecer sumiu da Pauliceia desvairada.

Seguiram outras, não com tanta fama, mas, "muitas proprietárias das pensões alegres e rendez-vous ficaram famosas na história da cidade, muito mais pelo seu lado bonachão e aconchegante do que pela exploração econômica que exerciam sobre suas subordinadas". 108

O tráfico internacional de mulheres na América do Sul se concentrou principalmente em Buenos Aires e Rio de Janeiro. Em 1879 a polícia do Rio de Janeiro já empreendia uma forte repressão contra o tráfico de mulheres que forçaram os cáften e suas prostitutas a migrarem para outras cidades. Estas diferem das outras estrangeiras, que vinham de livre e espontânea vontade para o Brasil com a nítida certeza que aqui ganhariam muito dinheiro: "eram mulheres que vinham fazer a América, isto é, tentar enriquecer ou pelo menos juntar um pé de meia para voltar ao país de origem ou radicar-se definitivamente no Brasil. Introduziram certas práticas anormais e tornaram outras corriqueiras colocando

\footnotetext{
103 LARGMAN, Esther. Jovens Polacas: Da miséria na Europa à prostituição no Brasil. Rio de Janeiro: Sindicato Nacional dos Editores de Livros, 2007, p. 39.

${ }^{104}$ Veja-se sobre o assunto, o instigante estudo de: MENEZES, Lená Medeiros de. Os estrangeiros e o comércio do corpo nas ruas do Rio de Janeiro (1890-1930). Rio de Janeiro: Arquivo Nacional, 1992.

105 EDMUNDO, Amaral. A Grande Cidade. Rio de Janeiro: José Olympio, 1950, p. 48.

106 RAGO, Margareth. Os Prazeres da Noite. Op. cit., p. 171.

${ }^{107}$ FONSECA, Guido. História da Prostituição em São Paulo. Op. cit., p. 199.

108 RAGO, Margareth. Os Prazeres da Noite. Op. cit., p. 175.
} 
as nacionais durante vários anos, praticamente fora da competição" 109. Àquelas, pelo contrário, vinham, comumente, enganadas por seus traficantes e aqui chegando, serviam como escravas sexuais, ganhando pouco ou quase nada de seu cáften profissional.

No Brasil de fins da década de 50, conforme nos informa Barruel de Lagenest, ao reunir dados de diversas cidades brasileiras, as meretrizes ou prostitutas trabalhavam em bordéis fechados ou abertos, na forma de "trottoir" e as que não viviam em bordéis, nem na rua, praticam o sexo ocasionalmente e marcavam seus encontros por telefone. 110

Os bordéis eram considerados abertos quando a prostituta não residia nele e seu vínculo era esporádico; enquanto o fechado era quando a prostituta nele morava e era completamente dependente da cafetina. 0 bordel podia ser também do baixo meretrício ou alto meretrício, dependendo do luxo e das mercadorias a disposição dos fregueses, com o alto meretrício geralmente se instalando fora do perímetro urbano das cidades. ${ }^{111}$

Um dos últimos bordéis fechados que insistia em sobreviver, apesar de toda repressão dos abolicionistas e das feministas foi a de Eny, em Bauru, que cerrou suas portas em 1983, não por algum decreto por perseguição, mas pela própria revolução sexual que despontara na década de 1960, trazendo em seu bojo a minissaia e as pílulas anticoncepcionais, e que mudaria os hábitos sexuais nos anos seguintes, tornando obsoletos os bordéis, a ponto de indignar a maior cafetina do Brasil:

A cafetina referia-se à mudança dos costumes, inconformada com o grande número de moças que já estavam deitando com os namorados antes do casamento. Para a corretora de amores, ter aquela multidão de clitóris inexperientes como adversários era demais. Um desperdício de moeda. A empresária sabia o valor da matéria-prima dos seus negócios. Com suas meninas em baixa, o mercado desvalorizado, não restava mais nada a fazer se não falir com dignidade e um gole de esperança. Elas abrem as pernas, eu fecho as portas. ${ }^{112}$

Percorrendo o tempo num vendaval, nem sempre constante, mas numa mesma direção, moldando-se aos espaços como o leito de um rio vai, driblando a implacável geografia repressora, e assim, contornando-a mansamente em

109 FONSECA, Guido. História da Prostituição em São Paulo. Op. cit., p. 132.

110 LAGENEST, Barruel D. H. Lenocínio e prostituição no Brasil. Op. cit., p. 22.

111 Idem, 74.

112 MELLO, Lucius de. Eny e o Grande Bordel Brasileiro. Op. cit., p. 272. 
cotovelos sucessivos, para seguir o caminho que inexoravelmente lhe carregará para o mar, a prostituição também seguiu em frente.

Neste pequeno introito percorremos não só, o nascimento do bordel clássico onde o sexo pago era consumado, mas também a vida e a decadência deles, desde o século XIX até meados do século XX. No percurso, procuramos ainda demonstrar como se posicionam os historiadores sobre a prostituição e os bordéis existentes no Brasil, desde América portuguesa até o início do governo Kubitschek, com a nítida intenção de verificar alguns subsídios de como os puteiros, surgiram na década de 1950 , se mantiveram no seio da sociedade manauara da década de 1960 e de como se extinguiram, dando vez aos motéis na década seguinte. 


\section{Capítulo 2 \\ Rendez-vous, Lupanares e Puteiros na Cidade de Manaus.}

Todas as noites se embrenhava ele lá pelas bandas da "zona fria" da cidade, onde funcionavam os cabarés Lá Hoje, Verônica, e o Rosa de Maio e outras casas do baixo meretrício. Sua mesa ficava apinhada de jovens, "mariposas" atraídas pela comida e bebida sempre à farta. Depois, já alta madrugada, ele levava para suas casas, em seu grande Jipe, aquelas que não conseguiam se "arrumar" com algum caboclo endinheirado ou um comerciante qualquer.

Áureo Nonato. 113

\subsection{Os BORDÉIS NA BELLE ÉPOQUE MANAUARA.}

Em Manaus o bordel em seu sentido amplo nasceu no fim do século XIX, percorreu todo o século XX e ainda era encontrado na primeira década do século XXI. Até o início da década de 1872, com uma população de pacos recursos e com pouco menos que trinta mil habitantes em toda a Província ${ }^{114}$, não havia na cidade uma demanda por sexo pago suficiente que ensejasse a abertura de um bordel. Para os habitantes daquela região, bastavam os caminhos que levavam as lavadeiras aos igarapés da cidade; uma ou outra prostituta a disposição em alguma janela de casa mal afamada ou um quarto numa taberna suspeita.

No sentido estrito, o bordel clássico ${ }^{115}$ só chegou à Manaus junto com todas as pompas e novidades que o dinheiro proveniente do período em que a economia girava em torno do extrativismo da borracha propiciou. Sofisticou-se com a expansão econômica e se extinguiu poucos anos após a derradeira tentativa de revitalização da economia gumífera, em fins da década de 1940.

Mas além de seu sentido estrito, que teve por característica o confinamento das prostitutas em suas dependências, mantendo elas ainda um vínculo tanto afetivo quanto financeira com uma cafetina e submetido ao controle, efetivo ou

\footnotetext{
113 NONATO, Áureo. Os Bucheiros - Um memorial de infância. Manaus: Valer, 1997, p. 61.

114 PINHEIRO, Maria Luiza Ugarte. A Cidade Sobre os Ombros: Trabalho e conflito no porto de Manaus 1899-1925. 2a ed. Manaus: EDUA, 2003, p. 58.

115 Ver a discussão sobre o bordel clássico no capítulo anterior, p. 29.
} 
não, do aparato sanitário, policial e social. Passaram a existir os bordéis abertos, chamados pelos franceses de rendez-vous, que na sua origem era praticado no começo das tardes, mas que, com o tempo, caracterizou-se como o bordel em que as prostitutas moravam fora do recinto que trabalhavam e não dependiam inteiramente da dona do bordel, embora lhe pagassem uma determinada quantia em dinheiro ou alugassem seus quartos, além de responderem às normatizações e controles dos órgãos policiais e sanitários.

Em Manaus, de meados da década de 50 até o ano de 1974, este tipo de estabelecimento, com suas variantes e especificidades, fora chamado pela população masculina que o gerou e sustentou de puteiros, enquanto pela imprensa - sua mais terrível combatente, que também assumia o papel de representante da moral e dos bons costumes - eram chamados de lupanares, rendez-vous, antros de prostituição ou antros de licenciosidade. É no entendimento do fazer-se dos prostíbulos, na percepção que deles tinham os frequentadores e nos mecanismos de defesa e resistência que entabulou frente ao ataque do resto da sociedade, que nossa pesquisa se direcionou.

A transição, ocorrida entre a segunda metade da década de 1970, entre esse tipo de bordel e o motel, se interpenetrando no espaço e no tempo, ocorreu claramente em Manaus com dois estabelecimentos - Selvagem e Saramandaia -, que assumiam um perfil misto, de lupanar, boate e dancing, sendo frequentados por uma nova geração que procurava outro tipo de prostituição, com características diversas daquelas anteriores.

A utilização do motel como local da prática do sexo pago reinou durante toda a década de 1980 e 1990, não obstante a permanência do baixo meretrício, que reinou no centro da cidade, na Rua Itamaracá e em suas adjacências desde século XIX, mas que servia às classes de menor poder aquisitivo. Os homens com médio e alto poder aquisitivo, no final dos anos 1990, voltaram a procurar um novo local, não só para a prática de sexo pago, mas também de sociabilidade dentro da cidade de Manaus, surgindo desta forma, no centro da cidade, mais precisamente na Rua Lobo D’almada, diversas boates que exibiam Streep tease e ofereciam prostitutas para seus fregueses, tendo como pioneira, a boate Rêmulos.

O bordel, portanto, como local de prática de prostituição não morreu. É evidente que o bordel clássico de Madame de Gourdan, em Paris, não tinha as 
mesmas características que o de Eny, em São Paulo116, nem o de Palmira, em Santa Catarina117, nem do "Lá Hoje”, de Manaus da década de 1960, ou do Rêmulos, já no início do século XXI, mas todos serviam de palco para o médio e o alto meretrício.

Manaus no tempo colonial e até meados do período imperial, era um pequeno aglomerado urbano, uma vila encravada na confluência dos rios Negros e Solimões e transformada em cidade e capital de uma nova Província em meados do século XIX. Contudo, "um primeiro e modesto incremento populacional parece ter ocorrido ainda no primeiro quartel do século XIX, fruto de um processo de centralização das atividades comerciais do sertão, então em deslocamento do Rio Negro para o Rio Solimões". 118

De acordo com os viajantes que passaram pela região, a população da vila evoluiu de 3.000 habitantes, em 1819, segundo Spix e Martius, para 8.500, em 1852, sendo mais da metade composta por mamelucos e índios, segundo Lourenço da Silva Araújo e Amazonas. Este é, na verdade, um número diferente daquele informado por Alfred Wallace, que residiu por dois anos na cidade e que informou ser de 3.000 o número de pessoas em 1851. Se formos dar ampla credibilidade a essas contagens, a população estagnou até 1867, conforme relato de Franz KellerLeuzinger, que afirmara ser de 3.000 o total da população da cidade. 0 certo é que em 1872, conforme recenseamento oficial, a capital da Província do Amazonas possuía 17.028 habitantes, incluído 493 escravos ${ }^{119}$. Ou ainda “... pulando de 5 mil em 1870 para 20.568 habitantes em 1890 e daí para 30.757 em 1900, ultrapassando em 1907 mais 60 mil. Os nordestinos, portadores da língua portuguesa, vão mudar a composição majoritariamente indígena da cidade. ${ }^{120}$

Desde sua fundação e até 1872, a cidade de Manaus tinha a maioria de sua população de origem indígena e mameluca, morando em palhoças humildes, tendo o pirarucu como seu principal produto de exportação e sendo abastecida de gêneros alimentícios pela importação promovida por alguns comerciantes

\footnotetext{
${ }^{116}$ MELLO, Lucius de. Eny e o Grande Bordel Brasileiro. Op. cit.

117 FIORENTI, Maryana Cunha Ferrari. Vila Palmira: Prostituição em Florianópolis e São José (19601980). In: FÁVERI, Marlene; SILVA, Janine Gomes e PEDRO, Joana Maria (Orgs.). Prostituição em áreas urbanas. Florianópolis: Editora UDESC, 2007, p. 195.

118 PINHEIRO, Maria Luiza Ugarte. A Cidade Sobre os Ombros. Op. cit., p. 32.

119 BITTENCOURT, Agnello. Fundação de Manaus: pródromos e sequências. Manaus: EDUA, 1999, p. 19-25.

120 FREIRE, José Ribamar Bessa. "Barés, Manáos e Tarumãs". Amazônia em Cadernos. História em novos cenários, $n^{\circ}$ 2/3. Manaus: EDUA, 1994, p. 173.
} 
portugueses. Dada a não existência um mercado público, verduras, peixes, carnes, tartarugas e farinhas eram vendidos em pequenas embarcações estacionadas na praia, geralmente aos sábados. À época da Implantação da Província do Amazonas (1852), a cidade era ainda "desprovida de canalização de água e esgoto, quase não possuía calçamento e a iluminação se fazia por precários e insuficientes lampiões a querosene, em numero total de 120" 121. Um ano depois (1853), possuía 243 casas, sendo 122 destas cobertas de palha.

A população branca, em sua minoria, impunha seu modo de vida, nem sempre acatado pela maioria mameluca e quase nunca pela indígena, sendo o vestuário à moda europeia, usado prioritariamente aos domingos, nas missas, passeios, piqueniques e visitas às casas de amigos. Esse segmento da população, era, em geral, exaltado pelos viajantes europeus que por aqui passavam, tanto quanto o modo de vida pacato e insosso. Alfred Wallace dirá: "dedicam-se todos ao comércio, não havendo ali qualquer outra diversão, se assim podemos considerar, que não seja a de beber e jogar em pequena escala" ${ }^{122}$. Infere-se, portanto, a ausência de um local específico para a prática de sexo pago até essa data, haja vista ser um detalhe de difícil esquecimento, não deixando de ser notado em pequenas cidades, muito embora o sexo fora do casamento e a prostituição tenham existido nesta época. ${ }^{123}$

A partir da segunda metade do século XIX a cidade de Manaus foi mudando seu perfil lentamente, para atingir uma mudança frenética no final do século XIX e primeiro decênio do século XX, num processo derivado do apogeu da economia gumífera124. Foram necessários investimentos na infraestrutura para facilitar o escoamento da borracha para o exterior e, dessa forma, os exportadores construíram com capital próprio o porto de Manaus, com a intenção de ampliação de seus lucros, mas também conseguiram importantes concessões dos serviços públicos, como da energia elétrica, dos transportes urbanos, da telefonia, água e esgoto, entre outros, ficando, em contrapartida, autorizados a administrar por longos períodos esses serviços. No caso do porto essa concessão era de 60 anos. Já o Estado, com dinheiro em caixa, fruto do aumento de arrecadação, investiu

\footnotetext{
${ }^{121}$ BITTENCOURT, Agnello. Fundação de Manaus. Op. cit., p. 7/22/15.

122 Apud BITTENCOURT, Agnello. Fundação de Manaus. Op. cit., p. 21.

123 DEL PRIORE, Mary. Histórias íntimas. Op. cit., p. 148.

124 PINHEIRO, Maria Luiza Ugarte. A Cidade Sobre os Ombros. Op. cit., p. 34.
} 
também nos serviços de asfaltamento de ruas, na construção de escolas, prédios públicos - alfândega, biblioteca pública, palácio da justiça, etc. - e na produção de espaços de lazer, como praças, parques, hipódromos, e casa de espetáculo, cujo ícone principal é o Teatro Amazonas. Bessa Freire sintetizou essa transformação:

\begin{abstract}
Surgem estabelecimentos bancários e lojas com nomes exóticos de Louvre, Au bom marche. A La ville de Paris, além de algumas residências majestosas, vilas, palacetes, bares, restaurantes, hotéis e cabarés, contendo em seus interiores móveis e tapetes europeus, pianos alemães, jarras de Sérvres e louça de Limoge. 125
\end{abstract}

Foram tantas as mudanças que o governado Eduardo Ribeiro exclamou "encontrei uma aldeia e deixei uma cidade moderna". Exagero! Primeiro que não foi ele e sim a conjuntura econômica da época que exigiu e proporcionou tamanha mudança, e em segundo lugar, muitas alterações já vinham sendo feitas desde a década de 1880, é claro que com menos intensidade que as da época de seu governo (1891-96). De mais a mais, muitas das obras não foram terminadas em seu governo. Pinheiro pontifica bem essa impessoalidade e o momento econômico propício ao informar que:

\begin{abstract}
O móvel impulsionador desta arrancada foi a crescente acolhida da borracha amazônica no mercado mundial. Tornando-se estratégica ao desenvolvimento da indústria capitalista, acorreram para a região os interesses do capital estrangeiro, patrocinando em associação com as elites políticas locais a montagem de uma infraestrutura necessária para garantir o acesso irrestrito ao produto. ${ }^{126}$
\end{abstract}

Manaus, para os primeiros historiadores, cronistas e memorialistas da época, transfigurou-se tornando uma cidade de arquitetura moderna, com um pungente comércio, consumidores ávidos pelos produtos lançados na Europa e com a incorporação de valores e trejeitos da Belle Époque, esquecendo-se de outra Manaus, de barracos, de ruas esburacadas, com carestia, dos grevistas, dos desempregados, dos vadios e das prostitutas decadentes. Novos historiadores tem tentado resgatar essa Manaus, dando ao período uma figuração mais eclética, posto que:

\footnotetext{
Mais de $60 \%$ das casas eram de taipa nua, coberta de zinco ou palha, pequenas de chão batido e socado, sujas. Igual porcentagem estava localizada perto de charcos, igarapés, rios e alagadiços, sem qualquer urbanização, sem esgoto, sendo invadida periodicamente pelas águas. A
}

125 FREIRE, José Ribamar Bessa. Barés, Manáos e Tarumãs. Op. cit., p. 173.

126 PINHEIRO, Maria Luiza Ugarte. A Cidade Sobre os Ombros. Op. cit., p. 37. 
maioria dessas casas possuía um só quarto mais abrigava de sete a noves pessoas, dormindo em redes, uns sobre os outros, sem água encanada.

As duas Manaus - a dourada e a favelada - sofreram as consequências da crise da borracha, que mergulhou a cidade no marasmo. 127

A Manaus da borracha, portanto, servia a dois arquétipos de pessoas, estando, de um lado, os novos-ricos, os "coronéis de barranco, seringalista, políticos, oficiais de alta patente, administradores públicos, juízes, promotores, advogados, importadores e exportadores"128 e grandes comerciantes que viviam abarrotados de dinheiros e sem limites de gastos. De outro lado estavam "carregadores, ambulantes, barraqueiros do Mercado público, marítimos, catraieiros, foguistas, estivadores, peixeiros, maquinistas, seringueiros de passagem ou de férias" ${ }^{129}$, além de comerciários e feirantes, quase sempre sem recursos e que, de forma tensa, conviviam nessa nova cidade.

A prostituição servia tanto ao barão da borracha quanto ao seringueiro, de uma forma ao grande aviador e de outra ao estivador, todos gravitando em torno da atividade gumífera. Inaugurando a era dos bordéis na Manaus da Belle Époque o alto meretrício surgiu na Epaminondas e na Rua Marechal Deodoro 130. Para Oyama César Ituassú:

$\mathrm{Na}$ fartura adquirida com a hévea, a cidade teve fase intensa em termos de vida noturna. As assim chamadas "pensões" não eram muitas segundo me narrava meu avô, Henrique Soares Pereira, ficando viúvo aos quarenta anos, viveu sua vida de nababo nessa época, aquelas casas eram dirigidas por madames de origem francesa e as jovens que ali atendiam à clientela, eram dessa nacionalidade, polonesas, espanholas e italianas, com predominância das primeiras. ${ }^{131}$

O baixo meretrício concentrando-se na Rua Itamaracá e São José dos Inocentes e um médio meretrício estava concentrado na Rua Lobo d'Almada e Joaquim Sarmento, nas confluências das ruas Henrique Martins e Saldanha Marinho. 132

O Baixo meretrício como em toda cidade que possui um porto, concentra sua atividade ao redor da vida portuária. Assim foi na antiguidade, em Corinto, com

\footnotetext{
127 FREIRE, José Ribamar Bessa. Barés, Manáos e Tarumãs. Op. cit., p. 175.

128 SANTOS JUNIOR, Paulo Marreiro dos. Pobreza e prostituição na Belle Époque manauara, 1890 1917. Revista de História Regional, 10, 2005, p. 89.

129 Idem, p. 94.

130 MELLO, Thiago de. Manaus, Amor e Memória. Rio de Janeiro: Philobiblion, 1984, p. 247.

131 ITUASSÚ, Oyana Cesar. Memórias do meu tempo. Manaus. Gráfica Gouvêa. 1998, p. 63.

132 SOUZA, Leno José Barata. Eva, Vadios e moleques. Canoa do Tempo, no 1, 2007, p. 44.
} 
suas duas mil prostitutas, no Porto de Miseno, com "o lupanar dos cem quartos", nos arredores de Roma antiga. Era assim também em Marselha, na França, em épocas mais recentes, como também foi assim e ainda é nas docas do Rio de janeiro ou de Belém do início do século XX.

O baixo meretrício sempre se caracterizou pela alta rotatividade dos clientes, geralmente marinheiros, estivadores, operários e estudantes; pela recorrência de prostitutas em fins de carreira que, frequentemente, vinham de bordéis ou das ruas e, por já terem sido substituídas por mulheres mais novas naqueles espaços, acabavam indo parar na "zona estragada". Em decorrência da grande oferta, os preços pelos serviços ali ofertados eram baixos. Na Manaus cosmopolita, acompanhando o raciocínio de Pinheiro, a imprensa passou a referenciar a zona portuária como "zona estragada", em oposição às novas edificações da cidade moderna. Vindo dos estratos populares, os personagens da zona estragada tinham ali o seu local para a prática do meretrício "e misturava-se com outros espaços de lazer popular, como os bares, botequins e "quiosques". 133

Leno José Souza nos revela que na Manaus daquela época existiam prostitutas que ficavam em janelas de suas residências, portando trajes indecentes e se oferecendo aos transeuntes. Estas, quando ofendidas, revidavam com palavras de baixo calão. Para o autor, essas práticas ocorriam nas ruas Epaminondas, Dez de julho, Costa Azevedo, e nos bairros periféricos dos Bilhares, Tocos e Cachoeirinha. A sociedade tendeu a reagir com regulamentos e com a intensificação do policiamento nessas áreas, mas sem muito sucesso.

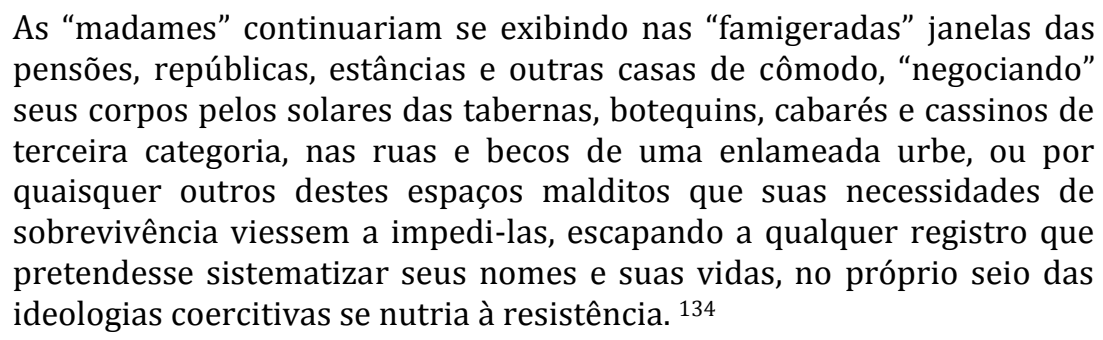

Esse tipo de prostituição fora relatado não só como existente na França prérevolucionária, deixando de existir ali juntamente com o século XIX, mas existiu

133 PINHEIRO, Maria Luiza Ugarte. A Cidade Sobre os Ombros. Op. cit., p. 53.

134 SOUZA, Leno José Barata. Eva, Vadios e Moleques. Op. cit., p. 40. 
dessa mesma forma também no Rio de Janeiro do inicio do século ${ }^{135}$, tanto quanto em Caxias, no Rio Grande do Sul. 136

0 alto meretrício em Manaus servia aos barões da borracha e tinham como prostitutas mulheres francesas, russas, polacas, que aqui aportaram em busca do dinheiro farto e viviam em pensões como a Pensão Floreaux, situada na rua Epaminondas, movimentando a noite manauara com suas idas ao Cabaré Chinelo, devidamente autorizadas pelas donas de pensões, sozinhas para dançar antes da obrigação do oficio ou jantar nos restaurantes e bares de então, como o Bar do Alemão, na rua Marechal Deodoro137. Novos hábitos também foram gerados, como expôs João Nogueira da Mata:

\begin{abstract}
Manaus nesses idos, das vinte e duas horas até pela madrugada, vivia do amor e para o amor, com as hetairas que vinham do Velho Mundo, na maioria francesas e polacas. Atrações internacionais com a perícia das deidades na conquista de comerciantes opulentos, de profissionais liberais, de seringalistas e de seringueiros de saldo, que acendiam charutos havanas com células de quinhentos mil reis. Esta estória que corre de foz em foz dos adeptos da boêmia noturna que imperava na Itamaracá, na Avenida Epaminondas, na Lobo d'Almada, na Saldanha Marinho e na Joaquim Sarmento. Pensões luxuosas, de cortinado de cambraia finíssima às janelas e iluminação deslumbrante. Orquestra em muitas delas. 138
\end{abstract}

Passando pelo mesmo processo civilizatório produzido pela economia gumífera, a cidade de Belém também recebeu suas prostitutas de luxo e que serviam aos mesmos tipos de clientes, demonstrando a mesma dependência cultural que a Cidade de Manaus possuía com a França:

\begin{abstract}
Os "coronéis da borracha" davam-se ao prazer de ter suas cocottes (prostitutas de luxo). Muitas delas europeias, como "Pranchita" (espanhola), "Raio de Ouro" (espanhola), "Margot" (francesa), frequentadoras das sessões das sextas-feiras do Cinema Olímpia, onde exibiam os vestidos luxuosos que mandavam buscar na Europa e joias da Casa Krauser. Os "coronéis da borracha", embora dependentes financeiramente de Londres e Estados Unidos, estavam culturalmente ligados a Paris, uma das cidades polos da Belle Époque, cidade símbolo da fase áurea da modernidade. 139
\end{abstract}

\footnotetext{
135 PASINI, Elisiane. Os homens da Vila: Um estudo sobre relações de gênero num universo de prostituição feminina. Tese de Doutorado. Campinas: UNICAMP, 2005, p. 43.

136 MATTÉ, Aline Karem. Prazeres velados e silêncios suspirados. Sexualidade e contravenção na região colonial italiana. (1920-1950). Dissertação de mestrado. Porto Alegre: PUC-RS, 2008, p. 124. ${ }^{137}$ MELLO, Thiago de. Manaus, Amor e Memória. Op. cit., p. 247.

138 MATA, João Nogueira da. Amazônia: Terra da Promissão. Manaus: Gráfica Rex, 1979, p. 67.

139 SARGES, Maria de Nazaré. Belém: Riquezas Produzindo a Belle Époque (1870-1912). Belém: PakaTatu, 2010, p. 113.
} 
Revisando a historiografia regional sobre o período, Leno José Souza tentou desmitificar não só o uso de polacas afrancesadas como predominante no seio do alto meretrício de Manaus, como também as coloca como protagonistas da zona estragada:

\begin{abstract}
Pelas docas da Harbour aportariam na cidade mulheres atraídas pelos ganhos fáceis propalados pelos políticos locais. Se uma historiografia clássica sustentou por décadas a visão quase mítica de uma prostituição vivificada exclusivamente por polacas afrancesadas de um meretrício luxuoso destinado a um seleto clube de notáveis, cuja figura mais famosa recai sobre os chamados barões da borracha; na prática, as prostitutas que animavam o meretrício local eram manauense, nordestinas e interioranas que, compelidas por necessidades extremas, lançavam-se em um concorrido "comércio de copos". ${ }^{140}$
\end{abstract}

Não obstante a luz lançada sobre as polacas no seio do alto meretrício, necessário que se faça dois senões ante tal afirmativa. Primeiro, a exclusão ou diminuição das francesas no auge da economia gumífera não parece ter sustentação, como atestam diversos relatos recentes como "o desaparecimento das francesas em direção a mercado mais lucrativos significou, como um médico norteamericano descobriu em 1916, que o grande comércio da prostituição de Manaus era comandada pelas polacas" ${ }^{141}$. Segundo há fortes indícios que houve realmente uma grande concentração de prostitutas nordestinas e interioranas na cidade de Manaus no início da década de 1920 e que as prostitutas estrangeiras, em sua grande maioria, já tinham deixado à cidade rumando de volta aos seus países ${ }^{142}$,

A borracha trouxe para Manaus, como se vê, toda a quintessência da civilização europeia: ... Mas trouxe também de cambulhada as caçadoras de ouro, louras, lindas e novinhas, com todo o cortejo de fascinação. Seduziam de todas as maneiras e retornavam às cidades de origem completamente endinheiradas. ${ }^{143}$

Muitas eram enviadas para aos seringais, para ali contrair casamentos e viverem como esposas dignas. Outras ainda migraram para o baixo meretrício, como expõe Mello, ao retratar a debandada geral nos idos de 1920: "os coronéis de barranco já não podiam pagar com fortunas uma carícia mais quente das francesas

\footnotetext{
140 SOUZA, Leno José Barata. Eva, Vadios e Moleques. Op. cit., p. 35.

141 ORUN, T. Thomas. As mulheres das portas abertas: judias no submundo da Belle Époque amazônica, 1890-1920. Manaus. Revista Estudos Amazônicos. Vol. VIII, no 1 (2012), p. 16.

142 UCHÔA, Samuel. Dois Anos de Saneamento, 1923. Manaus: Livraria Clássica, 1924. Apud Pinheiro, Maria Luiza Ugarte. A Cidade Sobre os Ombros. Op. cit., p. 65.

143 MATA, João Nogueira da. Amazônia: Terra da Promissão. Op. cit., p. 67.
} 
importadas e refinadas na arte do amor comprado [...] fora, substituídas nas pensões noturnas pelas nossas caboclas peitudas e de cintura menos delgada". ${ }^{144}$

Daí também se infere que os bordéis, chamado muitas vezes apenas de pensões, sobreviveram ao golpe da retração econômica provando mais uma vez seu poder de flexibilização e acomodação ante os percalços encontrados no decorrer dos séculos.

Observa-se que o local onde se praticavam a prostituição de luxo na Belle Époque manauara, e que perduraria até a década de 1950, tinha a simples denominação de "pensões" e eram no, primeiro momento, bordeis fechados ${ }^{145}$, com as prostitutas residindo no estabelecimento e dependente da cafetina. Essa denominação e esses locais não eram privilégio da pacata Manaus posto que em outras capitais brasileiras, como São Paulo, Rio de Janeiro e Minas Gerais utilizavam essa denominação nos seus locais de prostituição ${ }^{146}$, com um ou outro acréscimo como "pensões dos artistas", "pensões alegres", "pensões de mulheres". Se houve uma mimetização ou tentativa de imitação por parte da elite manauara ao transportar de outros centros esse tipo de meretrício, ou o espírito do tempo abarcou tanto o sul quanto norte no Brasil ao mesmo tempo. 0 que não se pode negar é a grande semelhança entre e as "pensões" de outras cidades e as de Manaus das décadas de 1940 e 1950, descritas por Jéferson Peres:

\begin{abstract}
Nas demais ruas predominavam as pensões, ou seja, bordéis dirigidos por ex-prostitutas, que cobravam aluguel das pensionistas e exploravam o serviço de bar. Só por exceção um cliente entrava diretamente para o quarto, sem a pausa obrigatória para uma cerveja ou uma dose de whisky. Alguns desses prostíbulos eram bem instalados, limpos com assoalhos encerados e cortinas nas janelas. Geralmente a dona, ocupava a sala da frente, que seria a de visitas, e as meninas utilizavam a alcova e os quartos da puxada. Na sala de jantar transformada em bar, era recebida a clientela. As pensões mais famosas e concorridas do meu tempo eram as da Lola e da Maria da Luz, vizinhas, na Rua Saldanha Marinho, e a Royal, na Joaquim Sarmento, a única que tinha nome, dirigida pela Hortênsia, uma mulher velhusca, alta, educada de aparência respeitável, que muitas vezes sentava à mesa para conversar com os frequentadores. 147
\end{abstract}

A prostituição na cidade entrou a década de 1950 utilizando esse tipo de bordel para a prática do sexo luxurioso e acompanhou o surgimento do rendez-

\footnotetext{
${ }^{144}$ MELLO, Thiago de. Manaus, Amor e Memória. Op. cit., p. 28.

145 Ver capítulo anterior, p. 32.

146 Ver capítulo anterior, p. 49.

147 PÉRES, Jefferson. Evocações de Manaus como eu vi ou sonhei. Manaus: Valer, 2002, p. 148.
} 
vous como local onde os casais procuravam unicamente para praticarem sexo e as prostitutas, salvo exceção, não moravam onde trabalhavam. Segundo Péres eram os precursores dos motéis, sendo os mais conhecidos o da Pensão Ritz, situado na esquina da rua Dr. Moreira com o Beco do Comércio, no centro e que tinha como proprietária a russa Flora Lifsitch, e o de uma barbadiana, no bairro da Cachoeirinha, menos frequentado por ser distante. Para os estudantes, dizia: "se não havia dinheiro algum, o jeito era apelar para a pensão calango, expressão que designava os terrenos baldios e as ruas cobertas de matos". 148

Existem referências que sugerem que com o asfaltamento da Estrada do Paredão, ocorrido durante a segunda guerra mundial, a invasão nas terras do empresário I. B. Sabbá \& Cia e as ações correlatas de "saneamento moral" promovida pelo governo estadual propiciaram a abertura dos bordéis da Boca do Emboca até a Baixa da Égua:

\begin{abstract}
As polacas (profissionais do sexo) deveriam deixar a área central da cidade, cuja presença ostensiva em suas principais vias, afrontava a moral e os bons costumes da honesta e honrada família amazonense. Sem ter onde exercer seu mister, elas aceitaram o convite dos comerciantes do sexo, transferindo seus serviços para os bordéis que estavam se instalando na nova "estrada". 149
\end{abstract}

Os principais estabelecimentos daquela região eram o Cortina de ferro, com suas festivas "manhãs de domingo"; o Big Bar, localizado na entrada do Emboca e que funcionava até por 20 horas, possuindo além do bar, quartos atrás, onde moravam algumas prostitutas e que também podiam ser alugados para uma rápida sessão de sexo, além do Bar do Orlando, que resistiu até a década de noventa. Nesta época, o "bar era dotado de muitos quartinhos na parte dos fundos, que tanto serviam de moradia para as damas mais antigas do recinto, como de lugar de encontros rápidos, para quem procurava prazeres fugazes". 150

Nas entrevistas e nos jornais da época foram revelados a existências dos seguintes rendez-vous na zona urbana de Manaus e que ainda existiam na década de 1960: Cabaré do Almeida, no bairro do Morro da Liberdade, Cabaré do Carroceiro, no Beco Boa Sorte e a Buate Fortaleza, no Bairro do Educandos. Já no centro da cidade ficavam a Buate Odeon, os rendez-vous do Déde, Carolina e da

148 PÉRES, Jefferson. Evocações de Manaus como eu vi ou sonhei. Op. cit., p. 156.

149 FIGUEREDO, Aguinaldo Nascimento. Bairro de Santa Luzia: História e memória do povo do Emboca. Manaus: Edições Muiraquitã, 2010, p. 22.

150 Idem, p. 48. 
Elisa, na Rua Frei José dos Inocentes, o rendez-vous da Rosimeire, na Rua Saldanha Marinho e a Pensão Royal, na Joaquim Sarmento. Alguns desses estabelecimentos não possuíam quartos para a prática do sexo pago e serviam apenas de ponto de encontro, mas no afã de exterminá-los os jornais generalizavam atribuindo a eles idênticas características.

Não demorou e em meados da década surgiu, a margem do igarapé que corta o atual Clube Municipal, um bar denominado Bom Futuro. Para Thiago de Mello:

\begin{abstract}
Durante o dia o Bom futuro não se fechava à frequência das famílias que até lá chegavam em seus passeios domingueiros. Mas já o primeiro bonde de cada noite começava a levar os fregueses, jornalistas, médicos e intelectuais da época, acompanhados de moças alegres, que faziam daquele recanto no meio da mata um dos prediletos campos da boemia da cidade, enriquecido pelas delicias das águas frescas de um igarapé que também desapareceu. As noitadas, que contavam com a animação de moças que chegavam desacompanhadas, às vezes se prolongavam pela madrugada, e alguns casais acabavam perdendo o derradeiro bonde. ${ }^{151}$
\end{abstract}

Mas logo prevaleceria o bordel. Segundo outro memorialista, "era um bar, restaurante e, nos fundos, um pequeno motel com poucos quartos para agasalhar os interessados. Devido a distancia os habitués eram poucos e muitos discretos, normalmente acadêmicos de direito e rapazes da sociedade". 152

Assim surgiu esse local que reunia nos finais de semana um bom quartel de prostitutas posta à disposição de homens que podiam se deslocar até aquela localidade de difícil acesso e estarem dispostos a pagar o serviço das prostitutas e o aluguel do quarto anexo ao bar. Não poderíamos classificá-lo de "pensão", pois as prostitutas não residiam no local, nem dependiam dos proprietários, como também não poderíamos classificá-lo como rendez-vous, por oferecer além do local para o sexo, o serviço de bar e servir de expositor de prostitutas. Seus frequentadores o chamaram de puteiro. 153

Logo a seguir debutam dois dos mais frequentados puteiros de Manaus,

O primeiro, com o nome de "Shangri-Lá" ficava na Constantino Nery, logo depois do atual Conjunto Cidade Jardim, com um grande acervo de prostituta novas e bonitas, cujas atividades começavam às 10 horas da noite, prosseguindo até amanhecer. Lá havia de tudo: homens do povo, rapazes da sociedade, senhores que em outras ocasiões eram

\footnotetext{
${ }^{151}$ MELLO, Thiago de. Manaus, amor e memória. Op. cit., p. 114.

152 ITUASSÚ, Oyana Cesar. Memórias do meu tempo. Op. cit., p. 65.

${ }^{153}$ Entrevista de "Carlos" realizada em 05.06.2005.
} 
circunspectos, escolhendo à larga suas preferencias femininas, todas gentis e comportadas. ${ }^{154}$

A localização exata deste recinto é onde hoje se localiza o Conjunto Habitacional do Kennedy. Esse puteiro, segundo Ituassú, era mais popular e mais violento do que o "Lá-Hoje", tido como discreto e melhor frequentado:

\begin{abstract}
O segundo Bar-cabaré denominava-se "La Hoje" e ficava no local onde atualmente é a Estação Rodoviária. Era um casarão enorme, em formato circular, afastado da estrada, com pista de danças onde, onde à meia noite, havia uma exibição de dançarinos de samba. Nos fundos do terreno, que era grande, havia uma série de quartos destinados aos casais que desejassem folgar mais aconchegadamente. Ambiente de respeito e muito tranquilo. ${ }^{155}$
\end{abstract}

Depois deles surgiram diversos estabelecimentos com as mesmas características e, com eles, se solidificou em Manaus o nome de puteiro. Assim surgiram no final da década de 1950 e durante toda a década de 1960 os seguintes prostíbulos: na Rua João Coelho, atual Avenida Torquato Tapajós, o puteiro "Verônica", localizado onde hoje é o Shopping Milenium, que já naquela época estava quase dentro da área urbana, localizado à margem direita do igarapé da Ponte dos Bilhares; o "Ângelos", localizado na esquina de um pequeno ramal em frente do Hospício, onde hoje fica a IMESA, com a Rua João Alfredo, hoje Djalma Batista; o "Iracema", que existia na rua ao lado da atual loja Solimões Veículos, também em Flores, o "Piscina Club", que se situava num pequeno ramal atrás do atual Posto 5; o "Mon Petit", que sucedeu o "Ângelos", em frente à atual fábrica da Philips, na Avenida Torquatro Tapajós; o "Bataclan", um pouco mais acima; o "Rosa de Maio", no ramal localizado após a entrada da cidade nova, onde na entrada temos o atual Motel Detalhes e, por fim, um dos mais antigos, o "Forquilha", que se situava na atual rua que leva ao Aeroporto Eduardo Gomes. Para a zona leste, no que é hoje a Avenida Cosme Ferreira existia o "Bafo de onça", onde funciona atualmente o Colégio Santana; o "Furna da onça", um pouco mais adiante. Para o lado do Rio Negro existia, dentro da Cidade Flutuante, o "Cai Nágua" e na zona oeste, na estrada da Ponta Negra, o "Mansão das Brumas" entre outros.

${ }^{154}$ ITUASSÚ, Oyana Cesar. Memórias do meu tempo. Op. cit., p. 70.

155 Idem, p. 72. 
Os puteiros com maior visibilidade na época eram o "Rosa de Maio", o "Verônica", o "Piscina Clube", o "Shangri-lá", o "Ângelos" e o "Lá Hoje" 156. Desses puteiros clássicos, o primeiro a morrer foi "Ângelos", em 1965 e o último o "Lá Hoje", em 1974. Surgidos na década de 1970 tivemos ainda os puteiros da Chica Bobó na Compensa, Maria das Patas no Aleixo e o da Chica Pacu, na Avenida Brasil, deslocados para a zona oeste. Foram, no entanto, o Selvagem e o Saramandaia, ambos localizados ao lado de onde é hoje o Colégio Denizard Rivail, na Estrada Torquato Tapajós, os últimos a receberem esse nome, embora já totalmente descaracterizados.

O Amazonas na década de 1960 era um estado com uma economia dependente das atividades extrativistas, cujos produtos exportados eram a borracha, a castanha, a balata, a ucuquirana, a sorva, a madeiras, o cacau, o guaraná, couros, peles e essências de pau-rosa, além do cultivo da juta, trazida pelos japoneses ainda na época da borracha, e que então desabrochara. Um observador da época comentou: "Tanto o baixo Solimões quanto o Baixo Amazonas têm suas margens cobertas por espesso tapete verde. São os jutais: a mais rendosa das atividades agrícolas da região". 157

Neste mesmo período, Manaus era uma cidade pacata, dependente economicamente da exportação desses produtos, dos salários dos funcionários públicos e dos repasses federais, sem os rigores do controle do tempo, a sesta era religiosamente cumprida das $11 \mathrm{~h} 30 \mathrm{~min}$ às $13 \mathrm{~h} 30 \mathrm{~min}$, como bem assinala Aguiar: "Manaus foi identificada como uma cidade provinciana e, portanto, desarticulada da relação direta com a produção industrial que estabelece novos critérios dentro de novas racionalidades para a vida na cidade". 158

A perda da concorrência da borracha para a Malásia, a não acumulação primitiva de capital que permitisse outra atividade econômica em substituição àquela extrativista, deixou o estado sem capital financeiro que ensejasse novos rumos à economia ${ }^{159}$, a não ser a intensificação do cultivo da juta que no ano de

\footnotetext{
156 Estes aparecem citados em quase todas as entrevistas, enquanto os demais, foram mencionados por alguns e, em geral, garimpados em jornais.

157 SERRA, Celso Luiz Rocha; CRUZ, Wilson Rodrigues da. Aspectos Econômicos e Sociais da Cidade Flutuante. Manaus: Gráfica Amazonas, 1964, p. 17.

158 AGUIAR, José Vicente de Souza. Manaus Praça, Colégio e Cinema Anos 50 e 60. Op. cit., p. 33.

159 FERREIRA, Márcio Alexandre Moreira. O Desenvolvimento do Capitalismo em Manaus. Op. cit., p. 15 e 23.
} 
1964 representava $34 \%$ da economia regional 160 . Os filhos dos grandes seringalistas e aviadores de Manaus retornavam de outros países ou estados, onde foram estudar, e agora juntamente com os bancários, altos funcionários públicos, juízes, desembargadores e comerciantes (posteriormente acrescido pelos despachantes), formando assim a classe média da cidade, que, com a inexistência de uma típica classe empresarial capitalista, era também integrante da elite da cidade.

Dos três últimos anos da década de 1960 até meados da década seguinte essa realidade começou a se transformar, e Manaus, de cidade pacata e morna com trejeitos de cidade europeia do início do século $\mathrm{XX}$, passou a se transformar em uma cidade agitada, efervescente, e com a face voltada para o modo de vida americano. Seus valores modificam-se, sendo lentamente abolida a sesta, enquanto o comércio deixava de prover somente seus habitantes para atender também os consumidores que vinham de outros estados em busca de produtos importados pela Zona Franca de Manaus. Esse momento também foi retratado por Aguiar:

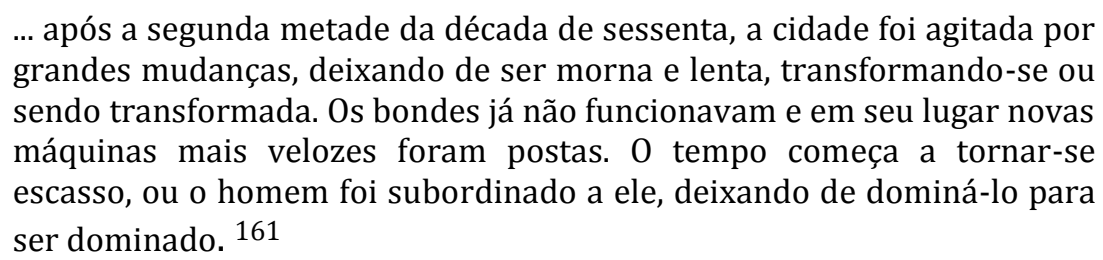

O comerciário, o bancário, o estivador, o motorista de praça, o serventuário e os funcionários públicos continuam sendo a massa trabalhadora que produzia a riqueza da cidade, sendo somente na década seguinte, com a implantação do polo industrial, que haverá uma mudança, com o aumento significativo do operariado:

Em 1968, Manaus tinha uma população de 245 mil habitantes e ainda não tinha indústria. Um pequeno empresariado de São Paulo, Mathias Machline, Issac Sverner, Léo Crys e Eugênio Staub, ergueu a Sharp, a CCE, a Evadin, a Gradiente criando milhares de emprego, aumentando consequentemente, a população de Manaus. Portanto, em 1980 [...] a Zona Franca já respondia por $85 \%$ da economia do estado. 162

Já que a lembrança criada no tempo presente interfere na do tempo lembrado, assim RG nos conta, com os olhos da década de 2010, como ele viu sua Manaus vivida na década de sessenta:

\footnotetext{
160 SILVA, José Lopes. Amazonas: do extrativismo à industrialização. Manaus: Valer, 2011, p. 396.

${ }^{161}$ AGUIAR, José Vicente de Souza. Manaus: Praça, Colégio e Cinema Anos 50 e 60. Op. cit., p. 34.

162 COUTINHO, Carlos Augusto. Manaus: Aspectos históricos e culturais. Manaus: 2006, p. 49.
} 


\begin{abstract}
Manaus na década de sessenta, no começo da Zona Franca em 1964, até final de setenta era uma cidade ilhada, em franca decadência, os ônibus de madeira trafegavam até onze da noite, os bondes tinham parado em cinquenta e cinco, o Plínio Coelho matou os bondes e a cidade vivia do comércio, pequenas indústrias, por exemplo, existia a fábricas de castanha, do I. B. Sabbá, a fábrica de cerveja, isto é, pequenas indústrias. Em Manaus as diversões eram o cinema e os balneários para as famílias e crianças e para os homens como eu e o Hamilton existiam os puteiros. 163
\end{abstract}

A percepção que o entrevistado demonstra quando alega uma "franca decadência" é que já houvera um apogeu e não era mais possível voltar a vivê-lo e após enumerar as atividades das categorias econômicas, remete ao (para ele único) lazer daqueles trabalhadores, ou seja, a ida aos puteiros. É possível que a criação do puteiro seja uma representação esquecida (em franca decadência), modificada das "casas de pensões" utilizadas pelos barões da borracha nas décadas de dez e vinte do século passado, que passou por uma longa transformação nas décadas seguintes, relembradas por João Nogueira da Mata, Jéferson Péres e Thiago de Mello e que por fim solidificou nesse novo tipo de lupanar.

Os bordéis do tipo que foram gestados em Paris surgiram na cidade de Manaus durante a Belle Époque e, pouco a pouco, foram se modificando, passando do fechado para o aberto, das francesas e polacas para as caboclas, acreanas e cearenses. A descaracterização dos bordéis tupiniquins seguindo o desmanche das "pensões" e a instalação dos "rendez-vous", propiciaram que dentro da cidade de Manaus brotasse um novo tipo de local para a prática do sexo, com novas características e sui-generis especificidade: o puteiro.

\title{
2.2. Puteiros: Entre PrÁticAs E REPRESENTAÇõES
}

A Manaus que respirou os primeiros anos da década de 1960 possuía uma população de 173.703 habitantes, chegando ao final da década com expressivos 311.622, habitantes segundos dados do IBGE. Geograficamente, no entanto, seus limites foram pouco alterados naquela década, em que a cidade ainda guardava o traçado e a fisionomia da Manaus que vivenciou a expansão da economia gumífera no início do século XX. Em 1968, os limites da cidade estavam assim definidos;

163 Entrevista com “Roberto”, realizada em 15.06.2012. 
Ao sul, o rio Negro; expandindo-se para o norte, para além do Boulevard Amazonas, através da Avenida João Coelho, segue-se o bairro da Chapada. Ainda ao norte, a área contígua ao Mocó por trás do Parque Amazonense surge o bairro de Jardim Amazonas; a leste, Adrianópolis; a nordeste, a Rua Recife seguindo até o Parque 10 de novembro, daí avançando para o norte até alcançar a estrada dos franceses onde encontra a Avenida João Coelho, entroncamento no qual se iniciava a estrada Manaus - Itacoatiara; a leste, os bairros de São Francisco, Petrópolis e a estrada do Aleixo; a sudeste, o bairro de São Lazaro, Colônia Oliveira Machado e o aeroporto de Ponta Peladas; a oeste, os bairros de São Jorge, estendendo-se à estrada da Ponta Negra; a sudoeste os bairros de Santo Antônio e São Raimundo. ${ }^{164}$

Alojados a norte e leste dos limites da Cidade de Manaus os puteiros criaram seus próprios territórios de influências e domínios. Nestes espaços são exercidos os controles de exclusão e inclusão do grupo sobre os indivíduos ou grupos de indivíduos demarcados por "limites simbólicos, como postura, forma de condutas, vestimentas, e até mesmo formas de comunicação oral. 0 limite da atuação territorial pode ser então, um limite cultural, comportamental, social, onde a pessoa diferente não pode usufruir o mesmo espaço por não pertencer a ele" 165 . A localização distante, por si só, já garantia certa privacidade aos frequentadores, mas o tipo de prostituição característico do alto meretrício, com todos os elevados custos que este exigia ${ }^{166}$, inibia, embora não excluísse totalmente a presença de homens de pacos recursos, o que não acontecia com a "mulher direita", esta sim excluída peremptoriamente do convívio naquele território. Portanto, havia um limite muito mais moral que socioeconômico.

Havia também uma cultura própria dos puteiros, codificada o suficiente para evitar constrangimentos, censuras e retaliações advindas do mundo de fora do meio. Assim, os putanheiros tinham seus próprios códigos, que usavam tanto dentro como fora da comunidade. Quando se encontravam em seus locais de trabalho, lazer ou mesmo num encontro fortuito na rua podiam se comunicar usando expressões que só eles entenderiam, como chamar a zona prostitucional de

164 OLIVEIRA, José Aldemir de Oliveira. Manaus de 1920 a 1967: a cidade doce e dura em excesso. Manaus: Valer, 2003, p. 95.

165 SILVA, Jan Carlos da. O conceito de território na geografia e a territorialidade da prostituição. In: RIBEIRO, Miguel Angelo. Território e Prostituição na Metrópole Carioca. Rio de Janeiro: Ecomuseu Fluminense, 2002, p. 31.

166 FREITAS. Renan Springer de. Bordel, Bordéis: Negociando identidades. Petrópolis: Vozes, 1985, p. 37. 
"clima frio", "zona fria” 167 ou "lá pra dentro". Nas entrevistas, percebeu-se que este era um código sempre relembrado com um misto de afeição e pertencimento:

Olha, a gente chamava "vamos para o clima frio", até aquelas festas que tinham lá de manhã, chamada Manhã de Sol, só domingo de manhã, nós estávamos no Fazendário jogando bola e dizíamos (para disfarçar dos outros) "vamos jogar bola lá dentro". Que nada, íamos era pra manhã de sol do Shangri-lá". 168

O puteiro "Lá Hoje", é um grande exemplo do uso de denominações e designações que assumem, para os "do meio", um claro duplo sentido, capaz, no entanto, de passar despercebido por aqueles que desconhecem o métier. 0 uso do trocadilho tornou-se bastante comum em Manaus, com os amigos frequentemente inquirindo-se mutuamente: "- vais lá hoje?" 169. Ao longo de um dia no trabalho, essa era, em geral, uma forma discreta e sutil de estruturar o grupo de amizade e convívio para uma visita ao puteiro. Da mesma forma, lembrar aos amigos que estava na "hora do Ângelos" 170, significava a intenção de deslocamento do centro para o puteiro "Ângelos", nas margens da cidade. A simples expressão "vais lá?" denotava certo grau de identidade e pertencimento de grupo possuía e, de resto, excluía os outros, os "de fora", mantendo as aparências de uma conversa banal e corriqueira.

Se entre os frequentadores do sexo masculino a comunicação fora dos domínios dos territórios dos puteiros era possível desta maneira algo cifrada, entre estes e as prostitutas existiam certas particularidades que precisavam ser respeitadas. Diga-se desde logo que, como regra geral, não deveria haver comunicação alguma, mesmo quando o cliente de ontem se encontrava com a prostituta de hoje. Em locais públicos tratavam-se como desconhecidos, exceção feita apenas quando o homem manifestava sua vontade de se comunicar e, assim, assumia as consequências desse encontro por sua conta e risco; ou ainda quando virava um xodó. Um entrevistado assim relembrou o encontro que tivera com uma prostituta fora do lupanar, em frente a colégios tradicionais da cidade:

Olha, às vezes eu encontrava com elas na praça do estadual [colégio Estadual D. Pedro II] ou do Instituto [Instituto de educação do Amazonas], todas vestidas de estudantes para enganar turistas quando

\footnotetext{
167 NONATO, Áureo. Os Bucheiros: Um memorial de infância. Op. cit., p. 61.

168 Entrevista com "Altair", realizada em 23.07.2012.

169 Jornal A Crítica. 04.06.12 A11.

170 Entrevista com “Roberto" realizada em 15.06.2012.
} 
vinham os navios. Tinha uma, a Odete que frequentava o "Lá Hoje"; encontrei com ela na praça da polícia e disse: "poxa eu estou alegre tu ta estudando", ela respondeu: tou não, eu tou é enganando turista. Ficávamos amigos. ${ }^{171}$

Esse respeito era cultivado ainda dentro dos lupanares, onde também existia todo um comportamento desejável, tanto para prostitutas, quanto para seus clientes:

\begin{abstract}
Eu cheguei a ver o "Lá hoje" e o "Verônica" e o "Shangri-lá". Do "Lá Hoje" era assim, você entrava... Só que naquele tempo as putas te respeitava, e você respeitava as putas, então era assim você chegava no puteiro, você dançava com aquela mulher que queria sair no momento, depois de sair a primeira [vez] já virava xodó, ai ela te ligava para vocês se encontrarem e irem a outros puteiros. Então aquela mulher uma ou duas mulheres na semana ou final de semana você já ia certo porque você se apaixonava pela puta. Era puta pra ficar... Era bacana por que assim você conquistava a puta dançando, mais tinha que pagar se transasse, você dava uma ponta, uma força pra ela. ${ }^{172}$
\end{abstract}

Não deixa de ser interessante perceber como o ambiente de sociabilidade que se estabelecia, mesmo entre prostitutas e seus clientes era intenso e complexo, jamais se resumindo a uma ida direta à cama, sem antes passar pelos volteios das danças e das conversas no salão, que muitas vezes podiam assumir feições de galanteios. Como se vê do depoimento, em meio a essas normas de conduta, o envolvimento sentimental entre prostitutas e clientes não era algo raro, mudando a relação, sem, contudo, a transformar radicalmente. Assim, o pagamento ao serviço prestado, na fala do (agora) xodó, pode mesmo transmutar-se em "uma força”, um auxílio, uma ajuda que se dá a alguém que se presa muito, mas jamais deixava de ser dado.

Essa postura de respeito mútuo fazia parte de um emaranhado de formas de condutas existentes dentro desses lupanares acompanhava os frequentadores desde sua iniciação - feita por intermédio de colegas ou de parentes mais velhos e experientes -, e eram postas em prática da chegada ao puteiro até a despedida da prostituta. Eis o relato de um frequentador que começou sua vida nos puteiros em meados da década de 1960 e que nos revela o cortejo necessário que era preciso na prática da prostituição nos lupanares da época:

Em 1965 eu cheguei (de Maués) em Manaus ai conheci o pessoal da Prefeitura que eram o R..., o A..., J. C..., e o Judicael, que foi nosso colega

171 Entrevista com “Joaquim", realizada em 11.10.2012, p. 13.

172 Entrevista com Ricardo, realizada em 26.07.2012, p. 8. 
e vereador, e todos eles gostavam de ir lá pro puteiro. 0 grande problema é o seguinte: os maiores eram o "Shangri-lá", o "Lá hoje" e o "Verônica" e depois com muito tempo o Selvagem, mas o que eu gostava mais era o "Lá hoje", por que quem ia lá era o pessoal melhorado, o quê que acontecia era o seguinte: você chegava lá dava uma volta no salão, sentava na mesa de três ou quatros colegas, depois dava uma volta para escolher a puta e depois perguntava se ela queria dançar com você; ai depois de ir pro salão o papo rolava e cerveja, cerveja, cerveja; você dali ia pro quarto, e depois voltava para beber com os colegas e o quarto era de madeira eu pagava pro dono o quarto e pra ela separado. Elas não moravam no puteiros, elas vinham de vários locais, se reuniam lá como um clube e os clientes também iam né, se morassem era só uma... Você pegava em vários lugares, naquele tempo era assim, agora na mesma época é como eu te falei tinha vários, existia três, quatro ou cinco; depois que apareceram os motéis porque naquele tempo não existia motel ai foi acabando [os puteiros] por que você preferia ir para o motel né, você já tinha uma graninha, mas naquela época tanto fazia você ter ou não ter grana você ia para o puteiro. 173

O sexo era pago mais não comprado indiscriminadamente, já que depois da escolha da prostituta era preciso uma abordagem indireta, pequenos gestos que permitissem à aproximação e o convite à dança. Gelo quebrado as partes conversavam dançando e bebendo, chegavam a um acordo sobre o preço, a duração e a espécie de sexo. Só depois é que pegavam a chave no bar, ou batiam na porta do quarto da encarregada de alugar os quartos e sedirigiam aos quartos, de madeiras e, portanto, cheios de brechas, que ficavam apartados do bar e do salão, para finalmente praticarem o ato sexual 174. Terminado o tempo, após ser pago o acordado, voltavam para o bar e, dependendo do grau de intimidade gerado no quarto, poderiam seguir juntos ou cada um para o seu lado; ela para próximo de suas colegas de trabalho, em busca de outro cliente; ele para junto de seus colegas, voltando a beber, dançar e a conversar até altas horas da noite ou mesmo até o amanhecer, vendo o sol raiar naquelas paragens.

Todo esse processo que tinha início com a escolha da prostituta, e findava com a saída do quarto, possuía variantes e estava, obviamente, sujeito a percalços, que muita das vezes não permitiam concluir a prática prostitucional. Por exemplo, não eram poucas as negativas das prostitutas ao convite da dança, principalmente se já tinham faturado bastante no dia ou se esperavam outro homem, de melhor

\footnotetext{
173 Idem.

174 Entrevista com “Fabricio" realizada em 04.12.2012, p. 16. A sequencia desses procedimentos, evidenciando uma abordagem ritual bem demarcada, apareceu em quase todos as entrevistas por nós realizadas.
} 
aparência física, que dançasse melhor (um pé de valsa ${ }^{175}$ ), ou mais generoso na hora do pagamento. Muitas vezes também, a negativa da prostituta podia estar ligada ao fato de ela ter conhecimento de alguma atitude desabonadora por parte do cliente. Na negociação, feita entre um gole de cerveja ou Rum Bacardi com limão e guaraná Andrade, e uma dança, ao som de Carlos Alberto, as propostas eram recusadas, aceitas ou renegociadas antes de se dirigirem aos quartos. A quebra de acordo, principalmente sobre o preço, praticada pelo homem era uma abominação dentro dos puteiros e, desta forma, uma das piores ofensas que um putanheiro podia ouvir, além de "chupador de b...", era ser chamado de "xexeiro". 176

Freitas define bem essas negociações entre clientes e prostitutas, classificando as práticas a serem negociadas entre as de fácil acordo - onde sem constrangimento eram combinados o coito, o sexo anal e/ou o sexo oral - e as que necessitam de um pouco mais de negociação. Incluíam-se neste caso as requisições de demandas afetivas - como beijos, carícias, etc. - ou a prestação de serviços fora do normal, como a "suruba", por exemplo. Os elementos comuns de toda e qualquer negociação eram, todavia, o preço a ser pago e o tempo de serviço na prática sexual.

Embora a prática acordada fosse de fácil entendimento, nem sempre era cumprida em conformidade com o estabelecido, gerando quebra de acordo, por exemplo, quando o cliente passava a exigir, no momento do ato sexual, prática que não fora combinada antes; ou quando a prostituta, por algum motivo, desistia de cumprir o serviço acordado, no todo ou em parte. Frequentemente o descumprimento dos acordos decorriam pela redução do pagamento feito pelo cliente após o serviço, razão pela qual passou a fazer parte do métier prostitucional o pagamento antecipado dos serviços acordados. 0 tempo também era motivo frequente de discórdia, com a prostituta tentando sempre encurtá-lo e o cliente, esticá-lo ao máximo. ${ }^{177}$

Não obstante o estudo de Renan Freitas ter sido feito na década de 1980 em Belo Horizonte e as práticas serem as mesmas na Manaus da década de 1960, a rotina e a negociações do preço e do tempo foram outras e estavam inseridas no contexto social da época. 0 ritual do puteiro em Manaus segue toda uma cultura

\footnotetext{
175 Entrevista com “Heleno", realizada em 03.12.2012, p. 12.

176 Entrevista com “Joaquim", realizada em 11.10.2012.

177 FREITAS. Renan Springer de. Bordel, Bordéis. Op. cit., p. 30.
} 
gerada no seu interior e que, embora tenha tido alguma influência externa e de tempos idos, possuíam toda uma caracterização e dramatização que só ali eram encontradas. Os preços acordados, diferentes da pesquisa de Freitas em outras formas de prostituição, raramente eram descumpridos, razão pela qual a exclusão dos "xexeiros" fazia parte desse ritual. De mais a mais, o descumprimento dos preços era bem menos comum nestes locais onde se praticava o médio e o alto meretrício:

\footnotetext{
Os bordéis de alto requinte - os rendez-vous de alto requinte e os motéis - supõem uma clientela de poder aquisitivo elevado e um padrão de demanda bastante sofisticado. Os programas custam, no mínimo, U\$ 15,00 e não há, como no caso dos outros bordéis, uma variação do preço em função da prática requerida. A combinação do preço já supõe a prestação de todos os tipos de serviço (com exceção de algumas perversões, que serão negociadas à parte). A versatilidade nesse contexto não só é uma coisa natural, como também é uma questão de honra profissional. 178
}

No entanto, o tipo de prática sexual, ou versatilidade, como usa o autor, não estava implicitamente ligado à variação de preço, nem tampouco atrelado a ele todo tipo de serviço sexual, muito pelo contrário; o que regulava a atividade sexual nos puteiros de Manaus era a negociação feita antes do ato sexual, estando nesta, inclusa o preço e o tipo de sexo. A se levar em conta o que dizem os depoentes da pesquisa, quanto ao tempo de sexo, parece não ter ocorrido nos puteiros de Manaus dos anos sessenta a mesma pressa constatada na pesquisa em Belo Horizonte. É possível pensar que, numa cidade ainda pacata e provinciana, o tempos passasse mais lentamente, sem a dinâmica frenética vivenciada pelos habitantes das grandes cidades.

Em Manaus, o tempo gasto no "serviço" começava bem antes do sexo, ainda na paquera, na dança, na conversa, na bebida no bar ou no salão. Era um tempo não cobrado, se o relacionamento terminasse no quarto; se, no entanto, esse tempo começasse a se alongar, a prostituta perguntava as intenções do cliente, fazendo-o deixar claro se haveria ou não o ato sexual. Caso a resposta fosse negativa, sem constrangimentos ela poderia decidir encerrar a conversa e procurar outro cliente, ou ficar por mais algum tempo, bebendo, dançando, "fazendo hora".

178 FREITAS. Renan Springer de. Bordel, Bordéis. Op. cit., p. 37. 
Daí se infere que o tempo durante o ato sexual em si não deveria ser, ao menos nos anos 1960, tão pequeno ou fracionado por hora, como depois passou a se generalizar.

Esse verdadeiro ritual de acasalamento iniciado na paquera, muita das vezes extrapolava as cercas dos puteiros, prolongando-se no espaço e no tempo, e assim, transformava aquela prática perene e fugaz, numa ação duradoura. Nestes casos, saia de cena o cliente, surgia o "xodó". Tomando ainda como base as entrevistas realizadas, parece não ter sido uma prática comum nos puteiros de Manaus, o caftinismo em seu conceito clássico, mas existiam tanto homens que protegiam as prostitutas em troca de sexo e dinheiro ${ }^{179}$, quanto àqueles que se envolviam sexual e emocionalmente com elas. No primeiro caso, estavam os tanto os cafetões, quanto os gigolôs. Sobre estes últimos, comenta Estácio Lima:

Em todas as cidades do mundo existe o primeiro grau do caftinismo, que é representado pelo "gigolô"'. Ele não é propriamente um explorador de mulheres. Ele não paga, mas é mais ou menos bem recebido no ambiente prostitucional. Às vezes é um estudante, às vezes um "chauffeur", às vezes ninguém sabe o que seja. É um individuo de classificação duvidosa, mas que não vive propriamente de explorar. 180

Quanto aos que se envolviam sexual e emocionalmente com as prostitutas, é interessante notar que as lembranças que mais afloram na memória dos sobreviventes dos puteiros sobre esse assunto, vêm em relatos que se sucedem num misto de satisfação e heroísmo quando falam de homens que se envolveram e até se casaram com prostitutas. Mais cativo emocionalmente que o "gigolô", o xodó manauara bancava integral ou parcialmente a prostituta, ou apenas demonstrava uma preferência no convívio e na relação sexual com ela dentro do puteiro. Para um dos entrevistados, "algumas mulheres do puteiro eram mais bonitas do que mocinhas de família, dava de 10 a zero, por isso os homens viravam as cabeças" 181. Com isso estabelece o reconhecimento de que as prostitutas dos puteiros podiam ser cativantes de muitas formas, sendo uma delas, a beleza.

Chamou a atenção a recorrência com que apareceu nas entrevistas o exemplo de uma prostituta sustentada por um putanheiro, de cujo envolvimento terminou em tragédia. Um dos depoentes diz:

179 Entrevista com "Roberto", realizada em 10.03.2013.

180 LIMA, Estácio. Prostituição: Tragédia Humana; In: LAGENEST, Barruel de. Lenocínio e Prostituição no Brasil. Op. cit., p. 116.

181 Entrevista com “Fabricio", realizada em 04.12.2012, p. 15. 
Eu assisti um juiz de direito de nome $\mathrm{X}$ que era dono do Hotel $\mathrm{Y}$, no Centro de Manaus; estava lotado num município perto de Manaus, ele tinha uma amante puta que quando ele ia embora caia na sacanagem. Ali no Shangri-lá, nós estávamos lá, tinha também carteado e eu jogava carteado. Ai ele chegou em Manaus e não a encontrou em casa foi até ao puteiro e ao encontrá-la deu dois tiros, beu, beu e matou, no meio da costa, dois tiro. Era um juiz de direito. 182

O caso foi bastante comentado, quase todos os entrevistados lembraram-se do caso, embora tenham sido abafados pela imprensa. À bem da verdade, alguns entrevistados divergem parcialmente sobre o assunto, indicando o cruzamento da Rua Joaquim Nabuco com a Rua Japurá como o local correto do crime. 0 memorialista Oyama Ituassú assim se manifesta sobre o ocorrido,

Nesse cabaré, houve em certa ocasião um incidente grave: um homem, magistrado de carreira, apaixonado por uma das garotas, por sinal bem bonita, foi desprezado por ela e, ao vê-la com outro, matou-a friamente com um tiro. Processado perante o Tribunal de Justiça foi absolvida sob o fundamento de perturbação mental e, por isso, foi aposentado mediante laudo médico atentatório de sua incapacidade. 183

Um caso típico que demonstra o putanheiro sustentando parcialmente a prostituta é o relacionamento que FB manteve com Odete. Eles estavam há meses se relacionando e com poucos recursos que possuía - FB era cabo da Aeronáutica ele a ajudava, "dava uma força para ela", como dizia, até que um dia foi informado que ela partiria para Macapá. Atônito, conseguiu dizer apenas “e eu aqui”. 184

Às vezes era o putanheiro que abandonava a prostituta, influenciado pelo ciúme que o meio em que ela vivia propiciava. Isso aconteceu com HAM que lembra: "Eu tinha uma namorada, bonita gostosa, que morava no bulevar e, só que ele chegou lá, ela trabalhava num bar e o dono comeu; ai o pessoal falava olha a Maria tal e coisa..., mas eu deixei ela..., ai fui para São Paulo."185 Depois de ter passado dez anos fora - onde casou e foi traído, lembra -, voltou à Manaus e reencontrou Maria, mas o tempo já esfriara tudo, sem contudo ter lhe tirado a dúvida cruel que lhe persegui: deveria ter se casado com ela? Ele próprio pondera que, se tivesse se casado com ela, que era uma prostituta, talvez não tivesse sido

\footnotetext{
182 Entrevista com “Antônio", realizada em 15.06.2012, p. 5.

183 ITUASSU, Oyana Cesar. Memórias do meu tempo. Op. cit., p. 72.

${ }^{184}$ Entrevista com "Fabricio", realizada em 11.10.2013, p. 14.

185 Entrevista com "Heleno", realizada em 05.11.2011, p.11.
} 
enganado, como o fez a "mulher direita", com quem se casou. Por fim, após um suspiro, dispara: “eu devia ter casado com aquela Maria!”. 186

A relação mais comum, porém, era aquela que só florescia dentro do próprio puteiro. 0 homem xodó, conquistado pela prostituta, passava a ser "propriedade" dela e, dessa forma, quando ele entrava no recinto, as outras prostitutas, na grande maioria das vezes, respeitavam essa posse e não mexiam ou davam confiança diante da "proprietária". Mas bastava esta se ausentar, para ser levantado o véu da proibição e a paquera correr frouxa novamente. Com efeito, a grande motivadora de conflitos, brigas e arengas entre as prostitutas dentro dos puteiros estavam exatamente relacionados com essas relações ${ }^{187}$. Por sua vez, os homens xodós respeitavam a profissão das suas parceiras veladamente, isto é, não brigavam por elas se prostituírem com outros homens, exceto quando da sua presença no puteiro, e essas relações chegavam a ser percebidas pelos outros frequentadores que, dessa forma, tendiam também a se recolher e esperar um momento melhor, ou deixar para fazer suas investidas em dias em que o xodó estava ausente. Essas tensões aparecem na fala de FAB quando se refere a sua relação com a prostituta Maria Come Gente:

Tinha uma mulher que eu comia que fazia Show no "Lá Hoje", depois eu descobri que o nome dela, era chamada de Maria Come Gente, depois eu encontrei com ela em frente ao IEA fardada. As meninas a chamava de Maria Come Gente. Tinha um cara magrinho que ficava com ela, eu ficava com medo, depois eu soube que ele era veado e que ele ia buscar ela para levar para os gringos, eu disse porra eu tava pra dar uma porrada nele. ${ }^{188}$

0 medo de FAB estava concentrado em não poder chegar perto da prostituta pela presença do rapaz, seu suposto xodó, muito mais do que pelo fato de ser ele um agenciador dela.

Algo que, todavia, deixava boquiaberto os putanheiros era quando sabiam que determinada prostituta deixara o puteiro para se casar ou "amigar" com outro putanheiro. Todos os entrevistados, sem exceção, conhecia pelo menos um caso. Carlos se lembrou do jogador de futebol que chegou à concentração e falou: “sabem a Fulana do 'Rosa de Maio'? Todos responderam sabemos, a puta!; ele retrucou, pois bem, a partir de hoje ela deixa de ser puta e passa ser minha mulher

\footnotetext{
186 Idem, p. 11.

187 Entrevista com "Fabricio", realizada em 04.12.2012, p.14.

188 Entrevista com "Joaquim", realizada em 11.10.2012, p.13.
} 
quero respeito. Foi um silêncio constrangedor" ${ }^{189}$. RC relata o caso de seu colega funcionário da prefeitura que tirou do puteiro Sicrana e se casou com ela: “...aí deu uma boa esposa; olha, teve quatro filhos, dois médicos, um jornalista e um advogado, todos formados" 190. HAM também "tinha um amigo que era taxista que se amigou com uma puta e teve um monte de filhos, A. B., ela deixou de ser mulher da vida..." 191. Mas o caso mais emblemático foi o relatado por RG:

Eu conhecia um taxista (M., da garagem Esportiva) que tirou uma morena de cabelo longo liso de lá (era puta e enfermeira) de nome N., foi morar na J. S., foi morar perto de casa, nos soubemos que ela era exprostituta, e fomos falar com o papai que disse, ex-prostituta para os outros, mas para nós é uma vizinha decente, quero todo mundo respeitando ela. Porque muita gente tirou mulher da vida e casou. ${ }^{192}$

Embora as prostitutas pudessem demonstrar certa dose de despeito pela instituição família, e, mais visivelmente pelas esposas e namoradas "formais" de seus parceiros, sair do puteiro e virar dona-de-casa era, explícita ou implicitamente, o sonho de quase todas elas. A última frase da citação explicita a grande quantidade de prostitutas da Manaus da década de sessenta que seguiram esse caminho. Era comum a "arenga" de prostitutas com seus xodós, quando o assunto era algum desses relacionamentos formais, momento em que ocorria delas imputarem às esposas/donas-de-casa e/ou a namorada/noiva desvios de adúlteras e promíscuas, para, assim, firmarem-se como pessoas "normais". Assim procedendo, nada mais faziam do que reinterpretar as representações que a sociedade, "os outros", faziam sobre elas. 193

Freitas reforça essa percepção do desejo de inversão de papéis, traduzido na vontade de ser uma "mulher honesta":

A imputação de um carisma às esposas tem, a meu ver, um sentido
bastante prático: o matrimônio (ou equivalente) é a aspiração máxima
da maior parte das prostitutas. Sendo assim, elas (independentemente
do nível) supervalorizam um papel que aspiram desempenhar: "olha que
vida idiota, ficar aqui deitada nessa cama esperando homem. Há esta
hora eu poderia estar em casa preparando a comida do meu marido para
quando ele chegasse do trabalho". Se desempenhar esta versão do papel
de esposa é um ideal a ser atingido (o mesmo ocorrendo em um nível de
expectativa mais restrito em relação ao papel de namorada), a prostituta

189 Entrevista com Carlos realizada em 05.06.2005.

190 Entrevista com "Ricardo" realizada em 26.07.2012, p. 8.

191 Entrevista com "Heleno" realizada em 05.11.2011, p. 12.

192 Entrevista com "Roberto" realizada em 15.06.2012.

193 FREITAS, Renan Springer. Bordel Bordéis. Op. cit., p. 88. 
deve tomar as pessoas que (ela supõe que) o desempenham como modelos de conduta. 194

Como demonstra Freitas, este fenômeno não era particular dos puteiros manauaras e nem mesmo da década de sessenta ${ }^{195}$, tendo sido encontrado em outros estudos, como a pesquisa de Margareth Rago sobre a prostituição paulista na Belle Époque, que assim se expressa:

\begin{abstract}
No entanto, procuravam valorizar-se diante das senhoras "respeitáveis", como mulheres que tinham acesso a dimensões e a segredos íntimos da vida sexual dos homens, ou às intrigas dos bastidores da política, de uma maneira que a esposa-mãe não possuía. Ridicularizar a sociedade burguesa, denunciá-la numa linguagem feminista ou satirizar figuras do "mundo respeitável" eram formas de destruição simbólica daqueles que as menosprezavam. A virgem sempre descrita como ingênua, mutilada ou "idiota", a esposa honesta enganada pelo marido, a adúltera como prostituta disfarçada e o casamento burguês foram temas recorrentes nessa crítica efetuada da margem. Contudo, muitas meretrizes aspiravam a esse tipo de vínculo afetivo e algumas, talvez um número expressivo, conseguiram casar-se com advogados ou fazendeiros de certo prestígio, abandonando a prostituição. 196
\end{abstract}

Grifamos a última frase por considerarmos simetricamente ajustado o desejo de casar-se e o efetivo casamento apresentado pela Belle Époque paulistana e pelos puteiros de Manaus da década de sessenta. Não raro todos os entrevistados davam noticias sobre esses eventos e alguns depoentes chegaram mesmo a contar mais de um caso. ${ }^{197}$

No imaginário do putanheiro - embora jamais no do homem comum - ter uma prostituta em casa com ares de dona-de-casa, e, desta forma, respeitada pela sociedade, e portando-se como alguém sem passado pela prostituição, era um objeto de desejo, um sonho que acabou sendo realizado por alguns daqueles, assumindo os riscos, casaram com elas, formaram famílias e, assim, foram felizes.

\footnotetext{
194 FREITAS, Renan Springer. Bordel Bordéis. Op. cit., p. 91.

195 Desenvolvendo estudos de gênero na região do Alto Juruá (Acre), no período da expansão da economia gumífera, Cristina Wolff registrou relato acerca do deslocamento forçado - promovido pelo Chefe de Polícia à mando do Governador do Estado - de prostitutas de Manaus para os seringais do Acre, em 1905. O objetivo era suprir a carência de mulheres nos seringais. De acordo com o relato: “Com tão estranha carga, encheu-se um navio cuja missão foi a de soltar, de distribuir as mulheres em Cruzeiro do Sul, no Alto Juruá. Houve, dessarte, um dia de festa - a de maior pompa, que se tinha visto. Amigaram-se todas, não faltou pretendente". Acompanhando o desfecho dessa história iniciada em meio à violência extremada, a autora pode coletar registros onde se afirma que elas passaram a assumir papéis familiares tradicionais no Acre e, dessa forma, "se tornavam boas senhoras, boas esposas, mãe de família, dedicada”. WOLFF, Cristina Scheibe. Mulheres da floresta: Uma história - Alto Juruá, Acre (18901945). São Paulo: HUCITEC, 1999, p. 86.

196 RAGO, Margareth. Os Prazeres da Noite. Op. cit., p. 239.

197 Entrevista com Roberto realizada em 15.06.2012
} 
Essa relação entre prostituta e putanheiro também foi alvo de pesquisa na sociedade de Teresina, onde, da mesma forma que nos puteiros manauaras, extrapolaram muitas vezes os muros dos lupanares:

\begin{abstract}
As relações afetivas no submundo da prostituição extrapolavam aquelas vivenciadas pelas meretrizes/madames e seus gigolôs. Mesmo constituindo o espaço de desterritorialização do desejo, de linha de fuga de conjugalidade, algumas relações vivenciadas no submundo eram capturadas pelas regras relativas à sexualidade legítima. Meretrizes cobravam fidelidade de seus amantes, disputavam entre si e brigavam por eles. Era comum que nos bordéis meretrizes mantivessem relações fixas com amantes específicos. Alguns chegavam a exigir, inclusive, fidelidade. Muitos homens casados, respeitáveis pais de família, mantinham prostitutas em cabarés ou em casas montadas e esperavam fidelidade [...] Encontros que ocorreram nas zonas transformavam-se em concubinato e, em alguns poucos casos, em casamento.

Essa captura de relações, na zona, por códigos que regiam a conjugalidade desencadeavam muitos conflitos e episódios trágicos. ${ }^{198}$
\end{abstract}

A constatação acima afirma que ao passar da situação de prostituta para esposa ou companheira, mudavam também os códigos que regiam as ações e relações até então.

0 relacionamento entre o homem frequentador e a mulher prostituta tinha todo um intercurso percorrido numa moral de estrito respeito entre eles. A prática continuada poderia gerar um novo relacionamento (o xodó), tanto quanto uma nova amizade. Os desvios de conduta, ou eram punidos veladamente, como a prática do devedor contumaz - o xexeiro -, ou sublimado com o casamento da prostituta com um cliente.

A visão que os putanheiros e frequentadores dos puteiros tinham de si mesmo, criando uma identidade de fácil percepção na linguagem, comportando-se dentro e fora dos puteiros com determinadas regras que lhe imputavam um grau de pertencimento, mais ou menos fixos, reconhecidos pela população da cidade de Manaus como algo palpável, engendraram multiplicidades de representações e costumes que o termo puteiro cristalizou-se dentro da sociedade manauara de então, tornando-o verdadeira instituição. Existia, concomitantemente, todo um ritual desde entrada até a saída do puteiro que emanava um emaranhado de relacionamentos intrínsecos, representações simbólicas e práticas recorrentes que deixaram em seus frequentadores a sensação de satisfação e bem estar.

198 CARDOSO, Elizangela Barbosa. Identidade de gênero, amor e casamento em Teresina. (19201960). Tese de doutorado em História. Niterói: Universidade Federal Fluminense, 2010, p. 252. 


\subsection{Apogeu dos Puteiros na DÉCAdA De 1960 em Manaus.}

Manaus, uma cidade com poucas áreas de lazer (praças, parques), sem televisão, com poucas e caras linhas telefônicas, mas com um rádio atuante e com uma grande parte da imprensa escrita dominada e feita por e para a elite, era uma cidade isolada, não só geograficamente, mas também culturalmente. É nesses meandros que o puteiro e seus elementos se solidificaram, floresceram e passaram a perturbar o sossego e a paz pública da sociedade, sendo atacados pela imprensa e reprimidos pela polícia.

Nada disso, entretanto, abalaram definitivamente os puteiros, que contraatacavam quando possível ou se recolhiam quando necessário. Seu desaparecimento em meados da década de setenta parece não ter sido por esses ataques e sim por profundas mudanças acontecidas no mundo e em Manaus especialmente, entre a década de sessenta e início da de setenta. Mas até lá os puteiros reinaram no lazer dos homens por toda década.

Os puteiros clássicos de Manaus ${ }^{199}$ eram construídos de madeira, coberto de telhas amianto ou zinco, tendo frequentemente a forma retangular, embora alguns fossem circulares e, em regra, possuíam mais de uma entrada, com abertura pelos lados e frente. Eram rodeados de uma meia parede de mais ou menos um metro e vinte de altura construída de ripas em xadrez e que partiam da parede do bar, circundando todo o estabelecimento e terminando na parede oposta. Dessa meia parede até a distância de duas mesas de bar instaladas com folga, ficava o local onde os frequentadores bebiam e conversavam. 0 espaço compreendido entre as duas fileiras de mesas, expostas em cada lado, a entrada e a carreira de mesa que ficava nos fundos, em frente ao bar, constituía o salão de dança, que podia ser oval, redondo ou retangular.

No início da década de sessenta as atividades ali eram iniciadas às três horas da tarde, com o enceramento do salão com "vela sete dias". 0 bar instalado ao fundo estava dividido em cozinha, caixa, a vitrola e sua discoteca, e, por fim, o

199 Nesta e nas quatro páginas seguintes foram consolidadas as informações colhidas nas entrevistas e nos registros jornalísticos de época. 
bar, propriamente dito, separado do salão por uma banqueta que isolava seu recinto e servia de encosto para os braços dos que bebiam em pé.

Unido pela vida e separado por uns trinta metros desse espaço "social", ficava outra instalação essencial do puteiro, a que incorporava o lado prostitucional do estabelecimento. Frequentemente alojando-se atrás do bar embora alguns poucos se instalassem ao lado - estavam, pois, os quartos. Germinados, eram construídos em uma só estrutura de madeira, sendo que não menos do que oito unidades compunha a instalação. Possuíam somente uma porta com três batentes para a entrada. Raros possuíam janelas e, quando as possuíam, eram alocadas de frente para a rua. Suas paredes, não possuindo ripas que vedassem a união das tábuas por completo, traziam o inconveniente de acabar permitindo a visão de quem quisesse "brechar" os amantes em seus momentos íntimos, embora, por outro lado, as brechas permitissem a passagem do vento, necessário para refrescar o casal ou casais ocupantes, já que o uso de ventiladores era raro e o ar condicionador, raro na cidade e com preço proibitivo, sequer se cogitava a existência naqueles recintos.

A mobília existente era pouca e simples, consistindo de uma penteadeira ou mesa, abrigando uma vasilha com água; a cama, postada num canto do quarto, com dois travesseiros e um jogo de lençol - nem sempre limpo -, uma toalha, meio sabonete e uma bacia de água no chão para a higiene da prostituta que ali fazia, o chamado "banho checo", assim denominado devido ao barulho que a água fazia ao ser jogada pela mão em direção ao órgão sexual feminino.

Existia um pequeno estacionamento ao lado, como no caso do Rosa de Maio, ou na frente, como no caso do Shangri-lá, mas sempre distante dos quartos para evitar constrangimentos. Choferes de praça sentavam no capô dos seus Gordini's, Jeep's, DKV's, Aero-Willys e Simcas, à espera de passageiros, ou conversavam entre si próximos aos veículos, ou ainda viravam clientes até o momento de voltarem para o centro de Manaus, quando voltavam a ser frequentadores e pegavam corridas, ou ainda davam carona às prostitutas.

Esta disposição do espaço parece ter sido comum entre os bordeis brasileiros, sendo também utilizada na década de 1950 na cidade de Caxias, no Rio Grande do Sul: 


\begin{abstract}
Nesse espaço estavam localizadas as duas mais famosas e duradouras casas de tolerância de Caxias: A Pensão Ângela e o Cabaret Salomé. Os dois espaços contavam com sala de baile, palco para apresentação musicais, bar para venda de bebidas e, aos fundos, encontravam-se diversos quartinhos individuais que contavam com uma cama de casal, e eram alugados pelas proprietárias aos frequentadores que se interessavam por alguma de suas meninas. E nas casas definidas como de "baixo meretrício" apenas encontravam prostitutas dispostas a satisfazerem os desejos dos que não podiam pagar os preços da grande zona. ${ }^{200}$
\end{abstract}

Uma diferença importante com o contexto manauara está no fato de que as casas de tolerância de Caxias do Sul empregavam o regime de rendez-vous fechado, ou seja, as meninas "pertenciam" as proprietárias das casas, enquanto os puteiros de Manaus praticavam o rendez-vous aberto, com as meninas morando fora dos lupanares. Por outro lado, esses dois contextos apresentavam-se novamente juntos quanto ao conceito de "baixo meretrício" e sua exclusão da grande zona.

Em Manaus, o complexo do sexo, singelamente batizado de puteiro, não estaria completo sem o igarapé, ao lado dos quais foram erguidos todos ou quase todos os puteiros da cidade. Normalmente sua área de utilização era cercada de madeira na margem, possuindo escadas que nasciam no fundo do igarapé e terminavam as margens servindo não só para entrar na água, mas também para sentar, beber e conversar. Esse tipo de "piscina" construída em igarapés, juntamente com os outros locais naturais, como as praias do Rio Negro ou debaixo de pontes de pequenos rios - como a Ponte da Bolívia -, eram denominados pela população manauara de "banhos" e, desde finais do século XIX, serviam para a população se refrescar, além de terem se mostrado espaços propícios para a prática de piqueniques nos fins de semana.

Assim o Bom Futuro - o primeiro puteiro - já estava instalado à beira de um igarapé. Esse igarapé é o mesmo que ainda hoje banha o Clube Municipal, embora poluído e sujo nas duas margens. O puteiro ficava na margem direita da Estrada Torquato Tapajós onde hoje funciona a Frigelo; O Verônica era banhado por um igarapé que ainda sobrevive, sendo o que hoje ladeia o Shopping Millenium; o banho do Ângelos ainda sobrevive, embora quase como um esgoto em frente do Flat Hotel, na Avenida Djalma Batista.

Quanto ao igarapé adjacente ao Rosa de Maio - que era tido como o que tinha a água mais gelada entre todos -, era acessado por meio de três ou quatro 
bifurcações que saíam do bar, deixando os frequentadores em total privacidade; 0 igarapé do Shangri-lá tinha por característica ser mais distante das outras instalações e, por isso, prestava-se muito para a prática do "acocho", momento em que o casal se lançava sofregamente a uma frenética sequencia de beijos e abraços mais licenciosos, com a prática simultânea de carícias íntimas mútuas. Ainda hoje o igarapé pode ser visitado, na pequena ponte existente entre as duas etapas do Conjunto dos Jornalistas. Já o Piscina Clube, como o próprio nome indica, tinha como atração principal sua piscina, que também era adaptada, usando-se o curso do igarapé. Outra piscina semelhante que ficou famosa era a do Iracema, que tinha a água tão límpida e pura que era usada para beber.

Ícone dos puteiros manauaras, tido como o mais "fino", lembrado por dez de cada dez putanheiros e o último puteiro a respirar na sociedade manauara, o LáHoje, entretanto, era desprovido de um igarapé. Fora instalado no entroncamento da Estrada Torquato Tapajós com a Rua João Alfredo, atual Djalma Batista onde hoje está instalada a rodoviária da cidade.

Nesses recantos - os puteiros -, escondido dos neófitos, reinou por quase duas décadas uma verdadeira instituição, com seus sujeitos, suas regras, seus trejeitos, sua especificidade no contexto e na cultura manauara. Suas principais personagens eram o putanheiro e a puta. Ele era representado por todo tipo de homem, mormente tivesse condição financeira razoável que lhe permitisse chegar ao longínquo local, consumir uma bebida ou comida que, todavia, era, em regra, mais cara que no centro da cidade, além é claro de ter numerário suficiente para a remuneração da prostituta.

Dentre os clientes que demandavam os puteiros, os mais frequentes eram funcionários públicos, comerciantes, juízes, desembargadores, políticos, despachantes, pequenos industriais e feirantes ${ }^{201}$. Além destes, tinham frequência esporádica os soldados em dias de soldo e os turistas estrangeiros, quando do aporte de navios, além de alguns estivadores em folga. Ia-se aos puteiros com os amigos, raramente sozinhos.

\footnotetext{
201 Essas categorias se repetiam em Caxias do Sul: “... além disso, exerciam as mais diversas profissões, destacando-se os residentes na cidade como soldados do exército e da polícia, os "choferes", comerciante, donos de estabelecimento comerciais ou industriais... alguns menores de idade e estudantes e agricultores.". MATTÉ, Aline Karem. Prazeres velados e silêncios suspirados. Op. cit., p. 144.
} 
As prostitutas, além das manauaras, eram oriundas das cidades do interior do Amazonas, dos estados do Pará e do Acre. Em média tinha entre 18 e 25 anos de idade. Viviam somente da prostituição, ou mesclavam com a de comerciária, operária ou empregada doméstica. A maioria morava nos bairros de Educandos, Colônia Oliveira Machado, Santa Luzia e Vila Mamão, embora em todos os bairros morasse pelo menos uma.

Para se deslocarem da cidade até os puteiros, os homens vinham com seus próprios carros, de carona, de taxi, frequente mente se cotizando entre amigos, Muito raramente iam de ônibus, que eram poucos a fazer rotas pelas margens da cidade. As prostitutas contratavam choferes de praça para lhes levarem aos puteiros - se cotizando ou não -, ou iam na carona com algum xodó. Iam também de ônibus, o que sempre incluía, depois da última parada, uma significativa caminhada até os locais de trabalho. Ao fim da jornada, esta última opção já não era mais possível, uma vez que não havia ônibus circulando na madrugada. Assim, invariavelmente voltavam de carona ou pagando um taxi.

Reunidos nesses lupanares estavam prostitutas, putanheiro e frequentadores, num emaranhado de ações e omissões, cristalizando o puteiro como uma experiência única no tempo e no espaço, tentando perpetuar-se no contexto e se fazendo texto dentro de uma sociedade que além de conservadora e provincial, buscava ser civilizada.

Fazendo parte do lazer dos homens os puteiros estavam, portanto, inseridos no sistema produtivo do trabalho, e muito embora, ainda não tivéssemos uma classe operária fabril pujante, já tínhamos categorias que reivindicavam seus direitos há décadas, construindo, na luta, o seu fazer-se, para empregar aqui uma acepção de Thompson. Para esse segmento ligado ao trabalho, ir aos bordéis já tinha sido um meio de fuga da opressão da mente e do cansaço do corpo desde meados do século XIX, na Europa, mas combatido sistematicamente pelos burgueses que agiram com,

\footnotetext{
A higienização dos bairros operários, a vigilância das suas casas e de seus hábitos, a edificação da família nuclear enclausurada no lar, protegida da presença de pessoas estranhas; o trabalhador constante e dedicado na fábrica, na mina, nas docas, etc.; um percurso da casa ao trabalho, e vice-versa, sem interrupções no bar e no cabaret; o tempo de folga bem utilizado nos afazeres domésticos, nos esportes saudáveis, na escola dominical... Tal é o projeto do fantástico trabalhador infatigável
} 
requerido pelo sistema produtivo ininterrupto na sociedade do trabalho. 202

0 tempo de folga lá, como na Manaus de 1960, deveria ser bem utilizado e, portanto, o lazer deveria excluir o bar e o cabaret, tudo para preservar a família nuclear, bem como obter o trabalhador infatigável e submisso exigido pelo processo produtivo da sociedade do trabalho.

A sociedade manauara, provinciana e conservadora dos anos de sessenta, buscando preservar a moral e os bons costumes, gestados há décadas, via-se agora como que agredida nesse intento, já que atacada pela existência dos lupanares nos confins de seus domínios. Individualmente a tolerância podia ser maior. Por exemplo, uma atitude tolerante para com as transgressões sexuais masculinas estava incutida na mente das mulheres a séculos e - embora as coisas estivessem mudando nesse quesito, essa tolerância aflorava a ponto das donas de casa não se importarem muito com a frequência de idas de seus maridos aos puteiros e até aceitar isso como inerente à condição masculina ${ }^{203}$. Os homens não putanheiros acatavam o senso comum de que os bordeis era um mal necessário ${ }^{204}$, se não pelo canal livre do sexo para uso da juventude, pelo menos para ocultar ou dar menos visibilidade ao que depunha contra a sanidade da sociedade.

Pudemos acompanhar pelos jornais da época, como essas questões e tensões eram debatidas no interior da sociedade. Costumes, valores e padrões sociais de comportamento eram não apenas debatidos, mas também incentivados pelos jornais, através de colunistas que, já em meados do século XX, contavam com a presença feminina em seus quadros, embora elas ainda fossem uma minoria no interior das redações dos jornais. Assim, em colunas assinadas por mulheres, quase toda semana os jornais amazonenses lembravam o que se esperava de uma mulher decente, direita, ante o matrimonio. Em 1959, a articulista Walkiria assim doutrinava:

O ideal da vida de uma mulher será: administrar sua casa com modéstia
e elegância; governar os criados com firmeza e docilidade; elevar-se ao
nível do marido por uma educação culta; partilhar o interesse de seus
pensamentos e de sua canseira; entreter as horas vagas com os encantos
dum espírito ilustrado; aconselhar, prevenir, alevantar e consolar; se o

202 BRESCIANI, Maria Stella Martins. Lógica e dissonância: Sociedade de trabalho: lei, ciência e resistência. In: Revista Brasileira de História. Volume 6, no 11. 1985. São Paulo: Marco Zero, p. 30. 203 Entrevista com "Barbara", realizada em 12.09.2012.

204 Entrevista de "Roberto", realizada em 15.06.2012. 
marido se transviar, reconduzi-lo ao seio da família, purificando tudo em torno de si com a sua própria pureza; e, se tudo estiver perdido, se circunscrever, irremediavelmente, a um amor sem esperança, ou a uma virtude sem estima e sem amor. Salve-se, então, por uma piedosa resignação. Eis aí o verdadeiro ideal da mulher, único que convém à sua alma terna e altiva, único que poderá preservar-lhe todo o encanto e sem nada lhe cercear de nobreza e dignidade. ${ }^{205}$

Essa visão de mundo engendrada pela sociedade patriarcal, e que fora explicitada por Bourdieu, nos fascina e nos engana ao mesmo tempo; primeiro pela benevolência e pela altivez de gestos de renuncias em nome do amor; segundo pela nulidade dos pensamentos e pela passividade nas relações. A dominação imposta pelos homens sobre as mulheres nada tem de natural, ela é uma construção cultural em que o dominador impõe sobre o dominado seus valores e crenças a fim de perpetuar essa relação, e um de seus reforços é a ideia de que foi, é e sempre será assim, fazendo que o dominado aceite sem questionamento o fato,

\begin{abstract}
Quando os dominados aplicam àquilo que os dominam esquemas que são produtos da dominação ou, em outros termos, quando seus pensamentos e suas percepções estão estruturados de conformidade com as estruturas mesmas da relação da dominação que lhe é imposta, seus atos de conhecimentos são, inevitavelmente, atos de reconhecimento, de submissão. ${ }^{206}$
\end{abstract}

Com efeito, desde o fim do matriarcado, a mulher viu-se inserida num mundo masculino. A perda de supremacia que tivera um dia - à milênios - fora classificada com progresso pelos estudiosos que defendiam o patriarcado, ou como derrota do matriarcado pelos mais realistas. Como nos ensina Michele Perrot:

\begin{abstract}
Mas para a maioria, (o matriarcado) trata-se de um estado primitivo e bárbaro. 0 direito materno constitui uma etapa no estabelecimento do direito, onde a filiação patrilinear marca o progresso decisivo. Para Bachofen, o direito paterno romano é um salto para a civilização. Apenas Engels destaca "a derrota histórica do sexo feminino", ligada à consolidação da propriedade privada, e vê na monogamia e sua forma moderna - o casamento burguês - a chave da opressão das mulheres. Ao contrário de Morgan, a quem tanto deve, Engels considera que essa evolução não é um progresso: em certo sentido, a idade de ouro está atrás de nós. 207
\end{abstract}

0 fato é que a mulher ainda era claramente governada pelo homem no inicio da década de sessenta, mormente em Manaus, cidade pacata e provinciana, onde o

\footnotetext{
205 Jornal do Comércio. 4.01.1959. Grifo nosso.

206 BOURDIEU, Pierre. A Dominação Masculina. Rio de Janeiro: Bertrand Brasil, 1998, p. 22.

207 PERROT, Michelle. Os Excluídos da História. Operários, mulheres, prisioneiros. Rio de Janeiro: Paz e Terra, 1992, p. 175.
} 
conservadorismo reinava forte e os ventos da mudança do feminismo ainda demorariam a chegar. A submissão era tanta na sociedade manauara que uma colunista chegou ao ponto de argumentar: "você pode jurar que sua esposa dirá a todos ter encontrado em você um marido perfeito se: ... c) sacrifique uma vez ou outra uma de suas saídas de 'solteiro' para ficar com ela". 208

Era desta forma que a imprensa reforçava a moral e os bons costumes da família gestada no casamento monogâmico burguês. Alguns desses costumes e hábitos eram reforçados pela doutrina dominante na igreja católica, para quem o casamento deveria ser eterno e que tinha o homem como cabeça do casal.

Parte da imprensa também pressionava o homem a adotar o modelo de bom marido e cumpridor das suas obrigações, de modo que tudo que impedisse essa realização era considerado como um desajuste da sociedade e deveria ser combatido. A prostituição impedia o processo civilizatório e isso era defendido amiúde nas matérias policiais porque ela "comprometia os foros de civilização e adiantamento da cidade de Manaus" 209, além e ferir "frontalmente os foros de Manaus como cidade em plena civilização". ${ }^{210}$

Os jornais atacavam não só denegrindo a imagem dos puteiros, mais também exigindo a presença do estado no combate ao que eles designavam de antros de prostituição. Essa perseguição já era notada no início do ano de 1959 quando o jornal $A$ Crítica assim noticiaria o fechamento de diversos puteiros:

Fechado todos os "Dancings" e "Rendez-vous" da cidade. Atendendo aos constantes reclamos da imprensa, o Dr. Domingos de Queirós, chefe de Polícia, a bem da tranquilidade pública e moral da família amazonense. As medidas postas em prática ontem pelo Titular do DESP que entrou em entendimento com o cônego Walter Nogueira Secretario do Interior e Justiça somente continuarão abertas os antros "Shangri-lá" e "Acapulco". 211

O estado era representado pela polícia e pela secretaria de interior e justiça que durante todos os anos sessenta fechavam e permitiam a reabertura dos puteiros numa conveniência latente, fato esse confirmado pelos frequentadores ${ }^{212}$ e pelas constantes notícias acerca dos mesmos puteiros durante anos nas colunas

\footnotetext{
208 Jornal do Comércio. 10.05.1959. Complemento Dominical. "Varinha Mágica”.

${ }^{209}$ A Crítica. 11.06.1965.

${ }^{210}$ A Crítica. 22.10.1959.

${ }^{211}$ A Crítica. 13.02.1959.

212 Entrevista com "Roberto realizada em 15.06.12, e com "Willian", realizada em 26.07.12
} 
de polícia. As ocorrências mais relatadas pelos noticiosos, além do uso e do tráfico de maconha, eram desavenças passionais, brigas entre mundanas e conflitos entre os frequentadores que chegavam às vias de fato.

O consumo de maconha acontecia na cidade, mas sua aquisição, segundo noticiada nos jornais, era feita frequentemente nos puteiros, como denuncia a manchete: “Traficantes de maconha no 'Shangri-lá' e no 'Rosa de Maio'”. A matéria relata o desatino de uma prostituta menor de idade, fugitiva do Educandário Maria Madalena, que se jogara de um sobrado localizado no centro da cidade e estaria "sob efeito de álcool, éter e maconha”. "Quanto à maconha, M.N.R. a recebia por intermédio de mulheres do Shangi-lá, Santa Gonzalez e Maria de tal, que por sua vez também distribuíam a 'erva da morte' a outras menores, a fim de irem para o bar 'Rosa de Maio' praticar atos de libidinagem uma com as outras (lesbianismo)".213

Ilustrando bem as paixões desenfreadas que aconteciam naqueles recintos, passamos a divulgar três casos que foram detalhados pela imprensa. Duas tentativas de homicídios e uma lesão grave ocorridas no início e no fim do período estudado, sendo o primeiro deles:

Paixão Mórbida. Abandonado pela bailarina da buate "Shangri-lá", o funcionário da Petrobras tentou matá-la. Madrugada de ontem, por volta das 4 horas, Noêmia Alves Belo, bailarina da buate "Shangri-lá", residente na Rua Dr. Moreira, n. 210 (Hotel Nova Olinda), compareceu na delegacia de Segurança Política e Social, para comunicar que, momentos antes, quando saia do seu camarim, naquela buate, seu ex-amante Moacir Wanderley, funcionário da Petrobras, residente no Hotel Brasília, tentou matá-la, não conseguindo por interferência de terceiros.

Narrando o fato, ou melhor, entrando em detalhes sobre o mesmo, disse Noêmia que vivera uns tempos com Moacir, resolvendo, porém a dias, abandoná-lo, o que fez de boa mente, pois dele "já estava enfadada". Moacir, entretanto - frisou a queixosa - nutrindo por ela uma paixão mórbida, não se conformou com a separação e passou a persegui-la, ameaçando-a de morte; ameaças essas de que ela não fez caso. Ontem, todavia, o seu apaixonado tentou concretizar o que lhe vinha prometendo há muito. Após ser preso e solto pela interferência do Advogado Mendonça Junior, foi novamente a procura de Noêmia, ameaçando de novo, matá-la. Paixão mórbida, não há dúvida, de Moacir. ${ }^{214}$

Caso típico do amor de prostituta para com o xodó, no princípio a vivência em comum e o epíteto de amante, depois o cansaço, o enjoo, o enfado e a decisão 
de abandoná-lo, gestada há dias e bem pensada, por fim o rompimento. 0 xodó não aceita e tenta manter o relacionamento a força, mesmo após ser preso e solto, volta a tentar manter o relacionamento. 0 dia seguinte não é narrado, nunca saberemos se Noêmia voltou a ser amante de Moacir ou não. 0 articulista apenas afirma ser aquela paixão, mórbida, fosse lá o que ele entendesse por morbidade.

O outro caso se passou em 1969 e teve como protagonistas duas prostitutas que foram à via de fato pelo amor de um xodó. A utilização de gilete como arma era uma característica constante nas brigas envolvendo prostitutas, buscava a atacante marcar o rosto da rival para diminuir a beleza da desafeta. Essa arma, portanto, não era privilegio deste caso especifico:

Por causa de "xodó" cortou a cara da rival com gilete. $\mathrm{Na}$ permanência do comissário Walter Rodrigues, na Delegacia de Segurança Pessoal, foram apresentadas pela patrulha de guarda civil as mundanas Walkiria Queiroz da Silva (18 anos, residente na Praça 14 de Janeiro) e Graciete de tal (Av. João Coelho) que por motivos de ciúmes travaram luta corporal na via pública culminando com a primeira sendo ferida com uma gilete no rosto.

Na central de polícia, Walkiria declarou que há alguns meses mantinha relações amorosas com fulano, boa pinta, mas não sabia ser o mesmo "amante" de Graciete. Quarta feira às 20 horas e 30 minutos, quando descia a Av. João Coelho, foi abordada por Graciete, que começou a ofendê-la com palavras de baixo calão, acusando-a de haver lhe roubado o "xodó". Após discutirem, Graciete sacou de uma lâmina de barbear e investiu contra Walkiria, ferindo-a no rosto, quando foi presa pela patrulha da Guarda Civil, que no momento passava pelo local.

Na DSP, foi aberto o competente inquérito para apurar os fatos. 215

Outro conflito envolvendo duas prostitutas por causa do amor de um homem ocorreu no Verônica, onde após se golpearem mutuamente foram levadas ao pronto socorro e depois recolhidas ao xadrez. Segundo o repórter:

Continuam as cenas de Sangue na "Verônica". Por volta, pois das $4 \mathrm{~h}$ $30 \mathrm{~m}$ de ontem, as mundanas Maria José Ferreira da Silva, residente na estrada da Panair s.n. e Gertrudes de Sousa, residente na rua Mucurani número 3, também no mesmo bairro. Ambas completamente embriagadas, por causa de um homem que as mesmas disputavam chegaram às vias de fato e engalfinharam-se no meio de salão daquele lupanar, onde elas desde cedo, em companhia de outros elementos, bebiam.

No mais aceso da luta, Gertrudes já bastante ferida e ensanguentada, lançou mão de um copo sobre uma das mesas e com o mesmo deu violenta pancada na cabeça de sua rival, abrindo-lhe o couro cabeludo, onde penetraram alguns fragmentos.

Presas então por um guarda civil que se encontravam no local, as duas contendoras foram levadas para o Serviço de Socorros de Urgência e,

215 A Notícia, 19.12.1969. 
depois de medicadas, para a Delegacia de Segurança Pessoal, onde o comissário Orlando Belota, de permanência, por determinação do delegado Antonio Lopes, mandou recolhê-las ao xadrez. ${ }^{216}$

Mas as brigas mais comuns eram entre frequentadores, e ocorriam na maioria das vezes quando se excediam na bebida alcoólica. A exposição é quase sempre de pessoas de pouca posse - peixeiros, bucheiros, feirantes, soldados, estivadores, guardas civis, policiais militares, praças do exército, agricultores - que se encontravam, não raro, em estado etílico e sem noção de sua conduta dentro dos puteiros: "já porque a bebida alcoólica ali [no Verônica] é vendida a rôdo, e os elementos que o frequentam - indivíduos desclassificados, meretrizes, etc. - são da pior espécie possível" 217. A generalização era a forma de atacar toda a instituição denominada puteiros. Em outro caso noticiado pelos jornais, o lupanar Rosa de Maio foi palco de briga onde houve verdadeira,

Chuva de Balas no "Rosa de Maio". Momentos de pânico viveu ontem à tarde o bar "Rosa de Maio", em Flôres, quando dois policiais, por causa de um civil se desentenderam, tendo um daqueles sacado de seu revolver e, desatinado, passou a atirar a torto e a direito, enquanto os que ali se encontravam fugiam em polvorosa, sob a chuva de balas.

0 conflito em apreço ocorreu por volta das 17 horas e, segundo fomos informados, assim se verificara: 0 indivíduo que atende pelo vulgo de "Manduca", proprietário de um botequim no interior do Mercado Municipal, se achava no "Rosa de Maio" em companhia do investigador Agenor Sampaio, da Delegacia de Segurança Política e Social, quando ali chegou o investigador Abdias Teles da Silva, lotado na Delegacia de Roubos e Falsificações.

"Manduca" que estava bastante alcoolizado teria desrespeitado o investigador Abdias, que reagiu à altura, travando-se entre ambos forte discussão na qual interveio o investigador Agenor Sampaio, passando este a altercar com aquele seu colega. Em meio à discussão Abdias perdendo a cabeça fez uso do revolver, descarregando contra Agenor e "manduca". As balas erraram todos os alvos. ${ }^{218}$

Além dos três envolvidos foram levados ao "casarão" da Marechal Deodoro [cadeia], inúmeras mulheres que lotaram dois carros. 0 interessante, aqui é que quem comunicou o fato a delegacia foi o próprio proprietário do puteiro. Outro desentendimento, envolvendo desta feita um policial voluntário, foi narrado na coluna "Carrossel do Cotidiano", de Carlos Esteves desta maneira:

O Lupanar. 0 famoso lupanar da Verônica voltou a ser assunto nos bastidores policiais com a desordem promovida ontem pelo indivíduo Expedito Januário, agente de polícia voluntária, que esquecendo sua

\footnotetext{
${ }^{216}$ A Gazeta. 27.02.1959.

${ }^{217}$ A Crítica. 30.11.1959.

${ }^{218}$ A Crítica. 10.05.1961
} 
condição de policial, tentou desarrumar aquele "dancing", em completo estado de embriaguês alcoólica. Sua fúria foi contida pela patrulha GE que o recolheu ao Xadrez. ${ }^{219}$

Um mês após, no mesmo puteiro foi a vez de dois soldados da polícia militar irem às vias de fatos e, após se esfaquearem, foram presos. 220

Outro ente estatal que rondava os puteiros era o juizado de menores que além de utilizar seus próprios agentes, solicitava o auxílio da polícia para fazer batidas nesses lupanares a fim de deter menores que eram recolhidos e só liberados quando os pais ou responsáveis compareciam a delegacia.

Os chamados tinham diversas causas, como denuncia de vendas de drogas e presença de menores:

Varias batidas - Atendendo à solicitação do juiz de menores, o Dr. Domingos de Queirós, Chefe de Polícia, em companhia daquele juiz, nos dias de sábado, domingo e segunda-feira deu varias batidas no "Rosa de Maio" e "Shangri-lá", inclusive na pensão da "Verônica", sem contudo, lograr êxito, pois nenhuma das traficantes fora encontrada. ${ }^{221}$

Outras chamadas eram feita pela imprensa como esta:

Frequência de Menores no Bar da "Verônica". O Chamado bar da "Verônica", em flores é o que há de mais perigoso para os que, incautamente, o frequentam, sobretudo a noite, quando grande número de indivíduos desclassificados que ali vão dar vazão às suas taras e instintos inconfessáveis. Pois bem, segundo fomos informados, de promiscuidade com meretrizes, malandros, rufiões, etc., grande número de menores frequentam aquele antro de licenciosidade e prostituição, sem que nenhuma providência fosse tomada, até o momento pelas autoridades competentes - no caso a Vara da Família - pois, por incrível que pareça, o vigilante de menores que fora designado para policiar aquele bar exerce no mesmo a função de garçom e, não raro, a de camareiro, indo aúrir a porta de quartos, para casais: razão por que, faltando-lhe força moral permite a entrada de menores naquele lupanar, os quais ali fazem o que bem querem e entendem.

Como se vê, o fato é vergonhoso e está a merecer imediatas providências do Juiz de menores; pois tal descalabro atenta contra o bom nome da vara de família. ${ }^{222}$

Em alguns anos a ronda era constante e habitual e os lupanares visitados eram os preferidos pelos menores. Os jornais, no afã de denegrir a imagem dos puteiros, davam epíteto a esses menores sem nem sequer se darem ao trabalho de investigar sua precedência, assim, em meados de 1962, o jornal A Crítica noticia:

\footnotetext{
${ }^{219}$ A Crítica, 16.08.1965.

${ }^{220}$ A Crítica, 19.09.1965.

${ }^{221}$ A Crítica. 12.02.1959.

222 A Crítica, 17.09.1959.
} 
Lupanar da Verônica é o preferido por menores desajustados. A ronda noturna da Vara da Família voltou atuar à noite de sábado nos lugares em que a frequência de menores é proibida, obtendo expressivo êxito, conseguindo retirar do lupanar "Verônica", grande número de menores que se encontravam naquele local desapropriado para os mesmos. Como se vê o lupanar "Verônica" é o preferido pelos menores mal orientados, por conseguinte um verdadeiro antro de perdição que em boa hora estar sendo rigorosamente fiscalizado pelos agentes da Vara de Família, através de rondas, com a finalidade precípua de evitar a frequência de menores.

Os menores foram os seguintes; JMR, de 17 anos, filho de Pascoal Rodrigues Rocha; EAR, de 17 anos filho de Domicio Rocha; MPG, de 17 anos filha de João Gomes; RMS, de 19 anos filha de Francisco Braga de Souza, MIA, de 18 anos filha de Antonio dos Anjos; MJS de 17 anos filho de Francisco Januario e MRPS de 17 anos filha de Antonio Romeiro. ${ }^{223}$

Dessa forma eram noticiados os conflitos ocorridos nos puteiros; tendenciosos, com alto apelo moral e sempre envolvendo os trabalhadores de baixa renda. Casos ocorridos com homens de alguma posse foram lembrados pelos putanheiros entrevistados, mas não são encontrados nos jornais, como o assassinato da prostituta pelo Juiz, acima mencionado. Outro caso nos relata RG, a título de exemplo, dizendo ele que, no final da década de sessenta, numa sexta feira, um juiz de direito e uma mulher casada - que aproveitara a viajem do marido para frequentar o "Rosa de Maio" - voltavam desse lupanar às cinco e meia da madrugada quando o carro dirigido por ele desgovernou-se e caiu da ponte do Parque Dez, aquela existente em frente ao DETRAN, onde agora há um viaduto. Ela Morreu e, pior, estava grávida. 0 ocorrido correu de boca a boca por toda Manaus, mas a imprensa não divulgou uma só linha.

Incrustado na provinciana sociedade manauara dos anos sessenta do século passado o puteiro respirava nas margens dos igarapés, recebendo todo tipo de putanheiro que chegavam de carros ou a pé, sozinhos ou acompanhados de amigos ou prostitutas, chegavam de todos os cantos da cidade. Os puteiros serviam de lazer para uma população masculina ávida de sexo e sociabilidade que a sociedade lhe negava. Pelo contrário o imaginário da década exigia a preservação da moral e bons costumes e os instrumentos utilizados era a repressão do estado, através da polícia, e o reforço junto com a denúncia da imprensa. A polícia prendendo alguns putanheiros e prostitutas que se excediam na bebida e provocavam arruaça no interior dos puteiros, e a imprensa noticiando pejorativamente esses conflitos. Esse enfrentamento de representação percorreu toda a década de sessenta e os

${ }^{223}$ A Crítica, 30.11.1962. 
primeiros anos da de setenta sem que houvesse, aparentemente, um vencedor, mas se a derrota significa o aniquilamento de um dos contendores, talvez tenha havido dois derrotados.

O presente capítulo, a princípio, procurou demonstrar um possível itinerário percorrido pelo bordel na sociedade manauara desde sua instalação em fins do século XIX com a introdução da economia gumífera até a metade da década de setenta com fase comercial da zona franca de Manaus. Presenciou o surgimento das pensões e as grandes levas de francesas, polacas, irem desaparecendo dando vez as peitudas caboclas; Passou ao largo da mudança de bordel fechado para bordel aberto nas décadas de trinta e quarenta e também do surgimento do rendez-vous tupiniquim para se concentrar nos puteiros da década de sessenta.

Procurou contextualizar o tipo de bordel com sua época e definir tanto sua geografia quanto a decoração; a separação do baixo meretrício e a localização mais distante da zona portuária; das luxuosas alcovas das madames aos banhos tchecos dos puteiros; da dependência da prostituta nas primeiras pensões à independência nos rendez-vous. Contudo sem perder o víeis do sexo pago, o "continuum" como substrato da prática prostitucional na sociedade Manauara.

Demorou-se um pouco mais na observância dos puteiros; descrevendo sua localização, sua arquitetura, seu layout, seus nomes e características. Adentrou, por fim, nos relacionamentos intrínsecos e extrínsecos dos putanheiros e prostitutas, surfando na memória dos sobreviventes e estacionando nos jornais da época, tudo numa tentativa de visualizar a dinâmica de um local parado no tempo e vivendo no imaginário de seus remanescentes. 


\title{
CAPÍTULO 3 \\ METAMORFOSE: DOS PUTEIROS AOS MOTÉIS.
}

\begin{abstract}
Nos velhos tempos do Ângelo's, Lá Hoje, Guaraciaba, Piscina, Selvagem, Rosa de Maio, Verônica, o termo apropriado era puteiro, "dos veras" mesmo, daí foi evoluindo para cabaré, lupanar, prostíbulo, depois motel e mesmo com toda materialização que a evolução lhe incutiu, o significado do termo atual pouco tem a ver com o antigo.
\end{abstract}

Flávio Lauria. 224

\subsection{Os Últimos Suspiros dos Puteiros: Travessias do Público ao Privado.}

Desde sua implantação na cidade de Manaus os puteiros foram perseguidos pelos defensores da ordem e dos bons costumes, tanto quanto foram as casas de pensões em idos passados e os estabelecimentos do baixo meretrício concomitantemente. Como todos eles também criaram mecanismos de autodefesa, ora utilizando a mesma arma do agressor, ora dissimulando uma perda irreparável ou ainda inovando, mas sempre conscientemente dando uma reposta a agressão. Paralelo a essa contenda existia outra mais profunda, com raízes no imaginário popular e que ocorria nas lutas de representações, no íntimo de cada homem untados numa geração. Eram os ares da contracultura adentrando na sociedade manauara que impunham seus ideários sobre o status quo reinante, modificando em médio prazo comportamentos, atitudes e hábitos.

Em meados da década de 70 entre tantos hábitos, deixamos de ter carro de praça e passamos a ter taxis; abandonamos a sesta e as cadeiras nas calçadas e adotamos o almoço comercial e as novelas da TV Ajuricaba. Também deixamos de ir aos puteiros - locais públicos por excelência e último baluarte do rendez-vous francês -, para irmos aos motéis privadamente. Se o bordel clássico floresce como uma instituição francesa, o motel é, por sua vez, uma instituição tipicamente americana.

As perseguições aos puteiros ${ }^{225}$ partiam, segundo os noticiosos da cidade, do reclamo da população e eram acatados pela autoridade competente, no caso a

224 "Ficar no Caritó". Jornal Amazonas em Tempo. 03.02.2011. 
delegacia de Segurança Política e Ordem Social, como bem ilustra essa reportagem vinculada no jornal $A$ Crítica em meados do ano de 1960:

\begin{abstract}
Atendido Nosso Apelo. Delegado Parente Acabou Com o Bordel da "Felicidade". Notificamos anteontem que o lupanar "Felicidade", o qual a muito, estava a exigir enérgicas e imediatas providências da policia para acabar com o mesmo, de vez que abrigava, na mais completa promiscuidade, um regular número de mundanas, as mais depravadas possíveis. Estas geralmente embriagadas e seminuas desrespeitavam as famílias residentes nas adjacências.

Em nome dessas famílias e do decoro público, que tem de ser resguardado, fizemos um apelo às autoridades policiais para que pudessem cobrar a tal irregularidade tão deprimente quão degradante.

0 delegado Raimundo Parente atendendo aos apelos que fizemos adotou imediatas providências, mandando no dia de ontem, que o comissário Mariolino Sá Pinheiro, de permanência na DSPS, intimasse todas as meretrizes residentes no mencionado local, a comparecerem ao seu gabinete, as quais eram; Lourdes, Pitoca, Aurea, Zenaide, Maria, Maria Acreana e Alice, as quais foram severamente admoestadas e intimadas a deixar, dentro de poucos dias, o citado bordel, sob pena de serem dali retiradas à força. 226
\end{abstract}

A veiculação da atitude da polícia constituía a última perna do tripé da agressão aos puteiros. A ordem dos fatos as vezes se alternava, vindo primeiro a veiculação e depois a repressão policial ou ainda primeiro a ação do estado para posteriormente ser detectada a ação dos jornais.

Os proprietários dos puteiros recorriam de vez enquanto, ou quando davam, no mesmo jornal, as suas defesas, alegando sempre se tratar de um local ordeiro que, na verdade era vítima da perseguição por pessoas que não gostavam deles. Alguns proprietários de hotel chegaram a anexar abaixo-assinados ou mesmo levar testemunhas as redações dos jornais para provar suas alegações, como é o caso do Cabaré do "Almeida":

Conflito no Cabaré do "Almeida". Urge uma Providência da Polícia Para fechar Aquêle Antro de Prostituição e Desordem dos Mais Sórdidos. Apesar de fechados todos os "dancings" e cabarés da cidade, pelas autoridades do casarão da Marechal Deodoro, no Morro da Liberdade, funciona um dos mais sórdidos, todos os sábados e domingos, conhecido por cabaré do "Almeida".

Ontem, por volta das 22 horas e 30 trinta minutos, naquele antro de prostituição e desordem onde a cachaça é vendida à vontade, por questões de bebidas e mulheres da vida fácil, que o frequentam, originou-se um tremendo conflito, havendo murros garrafadas e pauladas entre os seus frequentadores, saindo feridas cinco pessoas. $[\cdots]$

225 Assunto já discorrido no capítulo anterior, essa introdução faz-se necessário para agora percebermos a defesa dos puteiros.

${ }^{226}$ A Crítica. 18.05.1960. 
É estranhável que tendo o titular do DESP determinado o fechamento de todas as casas de dança, aquela espelunca funcione acintosamente, e mais estranhável ainda que o delegado Curió, do referido morro, permita tal funcionamento. Urge, por conseguinte, uma enérgica providência do Chefe de Polícia, para fechar imediatamente aquele antro, a fim de evitar que outros conflitos iguais aos de anteontem venham a verificar-se no mesmo, pois além do mais cremos que o cabaré do "Almeida" não possua nenhum privilegio para que funcione, enquanto os demais estão fechados. ${ }^{227}$

No dia seguinte, talvez pela força do sentido contigo no primeiro parágrafo da reportagem acima reproduzida, fecharam o cabaré e tanto o Delegado Geral instalado no casarão da Rua Marechal Deodoro quanto o delegado de Educandos alegaram o desconhecimento da existência do citado antro conforme reportagem:

Fechado Pela Polícia o "Cabaré do Almeida". Notificamos ontem com abundância de detalhes o conflito verificado no famigerado "cabaré do Almeida", no qual saíram à faca e a pau dois militares, um estudante e um agricultor, bem como um guarda civil, sendo a pancadaria motivada pelos péssimos elementos que frequentam aquela gafieira, inclusive meretrizes, e a bebedeira, pois a cachaça ali é vendida à vontade.

Todavia o delegado Severino Gomes, da Delegacia Geral de Educandos, tão logo soube da sangrenta ocorrência, determinou o imediato fechamento daquela espelunca. Segundo fomos informados tanto aquele delegado geral como as autoridades do casarão da Marechal Deodoro não sabiam da existência daquela sórdida casa de dança, que funcionaria, portanto, clandestinamente, sob o beneplácito do subdelegado do bairro da Santa Luzia, a cuja jurisdição aquele morro esta afeto. [...]

É deveras incrível, como se vê, o desrespeito às determinações do dirigente do casarão da Marechal Deodoro, que em tão boa hora encetou a campanha de moralização da cidade interditando o funcionamento desses antros de prostituição e libertinagem, onde frequentes são as desordens e as cenas de sangue, como as da madrugada de domingo último. ${ }^{228}$

O proprietário do cabaré, senhor Benedito Batista de Almeida, compareceu pessoalmente a sede do Jornal Gazeta onde prestou esclarecimento sobre o ocorrido nas imediações de seu estabelecimento familiar, segundo reportagem vinculada três dias após ter sido fechado pela polícia:

Defende-se o Proprietário da Sede do Almeida. As suas festas eram familiares - As brigas eram provocadas na rua, por gente Embriagada que comprava cachaça longe da sua casa comercial. $\mathrm{Na}$ manhã de ontem, esteve em nossa redação o senhor Benedito Batista de Almeida, trazendo um esclarecimento sobre as noticias que foram fornecidas à nossa reportagem, colocando a sua casa de dança em situação pouco recomendável.

Disse o sr. Almeida que ao contrário do que foi dito, as festas que se realizam em sua casa, são de caráter familiar, não sendo permitido ali a entrada de qualquer mundana. "Para isso provar - continuou - as 
minhas festas eram fiscalizadas pela polícia civil, juizado de menores e com autorização do subdelegado do bairro, nunca havendo em minhas festas, brigas ou até mesmo discussão".

"Para servir em tais festas", adiantou, "colocava minha esposa e a esposa do meu irmão para me ajudar, fato que justifica ainda melhor que a festa não era gafieira, pois do contrário não iria é expor seus familiares". Com relação a briga que motivou o fechamento de sua "buate" disse: "a briga foi passada do lado de fora e até muito longe da minha casa, cousa que eu não podia impedir e nem tinha nada a ver com isso. ${ }^{229}$

Aparentemente sem conseguir sensibilizar as autoridades com esse apelo solitário o senhor Almeida esperou mais dez dias e como não obteve êxito na reabertura da sua "buate", ou clube, como querem os vizinhos, ou ainda de "cabaré", segundo os jornais, e em mais um ato de resistência contra o sistema, reuniu alguns moradores, que deveriam ser frequentadores, para fazerem uma visita com ele à redação do jornal $A$ Critica munidos de abaixo-assinados para ser publicado naquele matutino e assim resignificar o tipo de estabelecimento, os frequentadores e culpar os agentes do estado - praças do Exército bêbados - e arruaceiros, e inocentar sua festa:

\footnotetext{
“Dancing” do Almeida é Familiar. "E não Devia ter Sido Fechado - As Brigas que Ali se Realizam Nada Tem a Ver Com a Festa - São Praças do Exército Embriagados Que Desrespeitam as Famílias Ali Existentes. Uma comissão de moradores do Morro da Liberdade, visitou manhã de ontem a redação do "melhor jornal" oportunidade em que pediu que publicássemos em nossas páginas, o seguinte:

"Nós moramos no Morro da Liberdade, e somos vizinhos do "seu" Almeida, dono da casa que realizava todos os sábados e domingos, festas familiares com a permissão da polícia e que era o único divertimento das famílias do bairro". A Briga que houve lá nas proximidades da festa, aconteceu com praças do exército, que aliás, todos os sábados e domingo fazem arruaças naquele local, bêbados e armados de facas, sem que a polícia, talvez por ser em menor número, possa tomar providências.

Disseram a seguir que a cachaçada no Morro da Liberdade se verifica todos os sábados e domingos, mesmo sem festas, daí acharem que a polícia não deveria fechar o clube, mais sim pedir a interversão do Comandante do 27 B.C. para mandar uma patrulha ao local, naqueles dias afim de prender tais moços que não sabem respeitar as famílias pobres que ali residem e deixar que as festas continuem, pois são elas os divertimentos do bairro. ${ }^{230}$
}

O cabaré do Almeida, pelo silêncio dos jornais, provavelmente foi reaberto o que não aconteceu Cabaré Chinelo que precisou recorrer ao judiciário obtendo um mandado de segurança e que mesmo quando esse foi cassado continuou a funcionar, "apesar de cassado seu mandato de segurança, funciona num flagrante 
desrespeito a lei, num acinte às autoridades policiais, constituindo-se um verdadeiro antro de prostituição, um local de desordem, pois raro é o dia em que ali não se verifica uma". 231

A condição se tornava difícil quando os vizinhos se aliavam a polícia e aos defensores da honra e da dignidade instados na imprensa manauara, foi o caso da "Buate" Fortaleza, da Sra. Ruth Monteiro, estabelecida na boca do Imboca, na entrada do Bairro de Santa Luzia. Após o fechamento a proprietária tentou de todas as maneiras reabrir o estabelecimento e não conseguiu, recorreu ao judiciário e obteve mandado de segurança favorável. A vizinhança recorreu, através de comícios, passeatas e ameaça de predação da "Fortaleza", caso ela viesse a funcionar. $\mathrm{O}$ desenrolar do conflito foi que aparentemente reabriu, haja vista, ser citado quando do fechamento geral dos dancings.

Mas no período analisado houve dois grandes momentos em que foram fechados quase todos os locais da vida mundana, entre eles os lupanares e os puteiros. 0 primeiro ocorreu no último carnaval dos anos cinquenta, aproveitando a cassação do mandado de segurança e o fechamento do Cabaré do Chinelo e seus derradeiros dias de secretario interino na frente da Secretaria de Interior e Justiça o Cônego Walter Nogueira “ordenou então, ontem ao Chefe de Polícia que pusesse em prática imediatamente aquela medida afim de, segundo fomos informados, deixar realizado um ato de moralização antes que assumisse o titular da STJ." As manchetes foram veiculadas em todos os matutinos e diziam mais ou menos o seguinte:

Fechados Pela Polícia Todos os "dancings" e "rendez-vous" da Cidade. Medidas Postas em Prática Ontem Pelo Titular da DESP de Acordo Com o Secretário do Interior e Justiça, a Bem da Tranquilidade Pública e da Moral da Família Amazonense Somente Continuarão Abertas "Shangri-lá" e "Acapulco", Buate Fortaleza um Caso em Estudo pelo Chefe de Polícia. O comissário Reginaldo Xavier que se encontrava em permanência aquela Delegacia Especializada escalou o escrivão Mariolino Sá Pinheiro, o investigador Alberto Lima e guardas civis para executarem o mandato.

Destarte foram fechados incontinenti a famigerada buate "Odeon", localizada bem no centro da cidade a qual era palco das mais desenfreadas licenciosidade e desordens, os "rendez-vous" da Rosimary, sito na Rua Saldanha Marinho; "Dedé", "Elisa", "Carolina", sito na Rua Frei José dos Inocentes ; “Verônica", "Ângelo" e "Rosa de Maio", no bairro de Flôres.

${ }^{231}$ A Crítica. 04.02.1960. 
Não obstante o fechamento geral de todos aqueles antros, o titular da DESP houve por bem deixar continuarem funcionando os bordéis, isto é o meretrício, por ser como alegou, um problema de dificílimo e até hoje ainda não resolvido em todo o Brasil, e as buates "Acapulco" e "Shangrilá", a primeira por ser frequentada por pessoas de nível social mais elevado; e a segunda idem.

Queremos crer que o Chefe de Polícia se equivocou quanto à frequência da buate "Shangri-lá" que é a mesma da buate "Odeon", cabaré do "Chinelo" e congêneres, pois a frequentam elementos de toda espécie e mulheres da vida fácil, inclusive viciada, conforme denuncia há poucos dias do Juizado de Menores, feito por intermédio desta folha.

Todavia, o Dr. Domingos de Queiroz concedendo este privilégio ao "Shangri-lá" determinou, entretanto, aos seus auxiliares que proibissem ali a dança entre pares, isto é, entre homem e mulher - ordenando o seu imediato fechamento caso transgredissem a norma - só sendo permitido o "show" e o jogo. 232

A geografia do sexo aqui é patente: três dos cinco puteiros clássicos são aqui citados e suas localizações são indicadas como estando na periferia da cidade, no bairro mais distante de então. Outra observação nas entrelinhas é que determinados puteiros por serem frequentados "por pessoas de nível social mais elevado", tinham um tratamento diferenciado dos demais.

A motivação fora a tranquilidade pública e a moral da família amazonense mas a que família se referia a matéria? Seria à todas indistintamente, ou somente às abastadas? Se não, porque não fechou também o baixo meretrício, alegando um problema nacional e de difícil solução? Será se apenas não queria admitir que a família a ser protegida fosse somente a da classe alta? Outra indagação latente era: à que moral se referia àquela advogada pelas senhoras casadas, pelos cônegos da cidade e defendida pelos articulistas de suplementos matinais que teimavam em civilizar a Manaus de então. Esqueciam que nos lupanares e puteiros da cidade podiam existir mais lealdade, recato e respeito que muitas famílias existentes na cidade conforme diversos depoimentos de seus frequentadores.

O outro momento ocorreu junho de 1965, quando, também aproveitando a interinidade do cargo, o delegado Dr. George Jacob decidiu fazer uma varredura no baixo meretrício e investigar profundamente os puteiros e lupanares do bairro de Flores. Enquanto no primeiro lacrava e determinava a saída das prostitutas do centro para a periferia; no segundo, a tolerância era latente quanto ao funcionamento:

232 A Critica, 13.02.59. 
Chefe de Polícia Faz Retirada de Meretrizes do Centro da Cidade. Desde ontem, a polícia começou a retirada das meretrizes das ruas Itamaracá e Frei José dos Inocentes, no centro da cidade, para eliminar, de vez, o lenocínio que ali existia há muitos anos, comprometendo os fôros de civilização e adiantamento da Cidade de Manaus. [...]

Por outro lado, a polícia manterá uma "ronda" permanente nas praças e logradouros públicos, para afastar o "passeio" de homens e mulheres suspeitos, assim como para vigiar o funcionamento as escondidas de bordéis que possam surgir doravante. Outro grupo de policiais ficara com a incumbência de investigar rigorosamente as "boites" do bairro de Flores, coibindo abusos, pancadarias e permanência de menores, como também ficou decidido que não serão reabertos os "bas-fond" denominados “Ângelos" e "Guaraciaba”. Pediu-nos até, o Dr. George Jacob, a colaboração de $A$ Crítica, na formulação de denuncias, para que seu trabalho tenha êxito. ${ }^{233}$

Percebe-se que a alegação dos repressores é o comprometimento dos foros de civilização e adiantamento da cidade de Manaus, como se postulassem que a prostituição deveria existir apenas na periferia, nunca no centro onde as famílias de bem habitam e os turistas passeiam, dai a ronda, dai o vigiar, dai o punir.

Quando se trabalhar a evidência oral, confrontando-a com outro tipo de fonte, no caso especifico a fonte jornalística, é comum perceber divergência entre elas e, dessa forma, o bom senso deve prevalecer orientando o julgamento à relativização. Além do mais, muitas das vezes os olhares de cada uma dessas fontes estão direcionados para focos diferentes, embora essa divergência não signifique necessariamente que se anulem mutuamente, já que uma evidência pode completar a outra. Como bem frisa Paul Thompson:

\begin{abstract}
quando houver discrepância entre evidência escrita e oral, não se segue que um dos relatos seja necessariamente mais fidedigno que o outro. A entrevista pode revelar a verdade que existe por trás do registro oficial. A divergência poderá representar dois relatos perfeitamente válidos a partir de dois pontos de vista diferentes, os quais em conjunto, proporcionam a interpretação verdadeira. ${ }^{234}$
\end{abstract}

Esse esclarecimento se fez necessário por haver, quanto ao fechamento do puteiro"Ângelos", duas evidências oriundas de fontes diferentes, a dos entrevistados e a dos jornais e, embora quase sempre em toda a pesquisa tenham divergido, nesta evidência ocorreu que uma complementou a outra de forma a corroborar ambas como verdadeiras.

E aqui as duas contendas enfrentadas pelo puteiros e lupanares se encontram, especialmente quando ficou decidido que o "Ângelos" não mais seria

234 THOMPSON, Paul. A Voz do Passado: História oral. São Paulo: Paz e Terra, p. 307. 
reaberto estava sacramentando a primeira morte de um dos clássicos puteiros da cidade. Sua agonia foi para nós descrita desta forma:

\begin{abstract}
Mas o caso interessante que eu queria contar era é que quando foi inaugurada essa avenida [João Valério] ele, o lupanar Ângelus, ficou exposto, visível, o igarapé passava, ele aterrou, e eram aqueles quartos de madeira, e a dona G. R., esposa do Governador A. R. e dona M. P., mulher do P. P. N., chefe de polícia, foram dar um passeio à tardinha quando elas passaram viram lá aquele casarão de madeira todo escroto, não pintavam o Ângelos a tempos, na beira daquele esgoto a céu aberto todo sujo e disse: "que diabo de casa velha é essa ai", o motorista disse é um puteiro, é o Ângelos, a hora, do hora do ângelus.. seis horas, Ai a dona G. disse não é possível, vamos lá com o P. P. N. vamos lá que ele vai fechar essa porra hoje. Essa falta de respeito com a sociedade dentro da cidade. O P. P. N., o Dr. Alberto Rocha baixou uma portaria fechando o puteiro Ângelo, ai o Nelson [dono do puteiro] que era casado com uma boliviana bonita era meu vizinho na Joaquim Sarmento, era dono da pensão Royal, também, um puteiro no centro. Ai rapaz ele foi lá comigo na secretaria de interior e justiça, você é meu amigo, vizinho, e eu era freguês de lá, tomava cervejinha lá, dançava com as meninas, eu vou conversar com o doutor Alberto, eu cheguei lá e falei, doutor Alberto o negócio é o seguinte, você sabe que esses puteiros são uma contenção social, essas casas de tolerância (terceiro), exatamente, ai ele falou foi à mulher do governador, se fosse o governador que tivesse fechado eu mandava abrir, mais foi a mulher do governador não tem, mas doutor Alberto Rocha isso é uma contenção, os cara ao invés de agredir nossas filhas, vão lá e descarregam, ai ele disse não tem jeito não, ali mesmo, está fechado e não abre, ai eu falei e se ele abrir em outro local e mudar de nome, ai ele disse ai é outra historia eu libero a licença, chamou o P. N. o cara tava pagando comida para as putas e não fazer nada, ai fizerem outro puteiro ali em frente a Philips, rapidinho ali. 0 nome de um samba, ai resultado... ele chegou feliz da vida e disse esta aqui um permanente pra ti e um pra ele, eu disse quer ser preso fila da puta, eu vou oferecer essa porra pra ele, vou ficar com o meu e olhe lá. 235
\end{abstract}

Esse cruzamento de informações da imprensa com as entrevistas ilustra o começo do fim os puteiros. O fechamento do "Ângelos" como acima descrito pelo entrevistado e a notícia veiculada na imprensa reiterando que não seria reaberto podem estar perfeitamente de acordo com o que de fato deve ter ocorrido. A ênfase em não reabri-lo, embora estivesse nos limites da cidade e numa área pouco povoada, deve-se a outros motivos, provavelmente à pressão da sociedade, via primeira-dama.

Já a defesa da abertura do puteiro, baseava-se na premissa de que eram necessários os lupanares, tendo em vista a proteção de "nossas filhas" contra a fúria do desejo masculino, sendo, portanto, imprescindível a existência do bordel para que "os caras" descarregassem seus instintos sexuais. Premissa essa

235 Entrevista com “Roberto”, realizada em 15.06.2012. 
advogada desde antiguidade e que no imaginário do entrevistado era uma "contensão social".

A alegação fazia sentindo se olharmos para aquela sociedade provinciana em que a virgindade era valorizada e o namoro vigiado. Mesmo nos poucos momentos em que os namorados ficavam sozinhos, a jovem tinha medo de se entregar, pois podia logo ser abandonada e, dessa forma, perder não só o noivo como sua honra, sua reputação. 0 jovem também tinha receio de "mexer" com a moça, pois poderia ser obrigado a casar, ser processado por sedução ou ainda ser ameaçado de morte pelo pai dela. Os pais eram severos com as filhas a ponto de mandá-las embora de casa se descobrissem que não eram mais virgens, no entanto eram incentivadores dos moços, levando-os, muitas das vezes, para a sua primeira relação sexual nos puteiros.

Existem diversos estudos analisando essa linha de defesa, mais o que interessa no presente caso é a sua existência na década de sessenta e mais ainda, inquirir se ela surtiu efeito na decisão, a ponto de o secretário aceitar a sugestão da reabertura do lupanar, em um local mais afastado. Se olharmos pela persistência e pela sagacidade do proprietário do Ângelos em ter seu puteiro reaberto mesmo que a pouca distância do original e com outro nome, percebe-se sua clara resistência aos imperativos da moral vigente.

O último puteiro clássico a fechar as portas foi o Lá Hoje, no segundo semestre do ano de 1974. Sua agonia foi relembrada por um de seus frequentadores da seguinte forma: “O Lá Hoje fechou em 1974, eu era repórter da Crítica, e fui cobrir um crime, mataram um cara e eu fui fazer a cobertura e a polícia anunciou que iria fecha e fechou, mas já tava tudo avançado, ele ficava onde era hoje a Rodoviária".

O proprietário do lupanar Piscina Clube alega que só fechou o seu puteiro no início da década de oitenta, quando "já não dava nenhum homem de bem e virou bagunça" ${ }^{236}$, alguns frequentadores confirmam esse fato como é o caso do jogador do Nacional que aqui chegou em 1979 e que foi levado a conhecer seu primeiro puteiro em Manaus 237. Mas para a maioria dos putanheiros entrevistados o fechamento do "Lá Hoje" foi o verdadeiro marco de extinção dos puteiros, pois os

236 Entrevista com “Fabio", em 23.07.2013.

${ }^{237}$ Entrevista com “Paraense”, em 15.08.2013. 
que restaram (Piscina Club) ou surgiram depois (Selvagem e Saramandaia) fizeram parte de um momento da transição para os motéis.

Desta forma o lupanar Piscina Clube passa a fazer parte, juntamente com o Selvagem e o Saramandaia dos puteiros de transição, isto é, já não tinham todas as características de um puteiro clássico, mas também ainda não era propriamente um motel, tendo em vista a prevalência do público sobre o privado. Neles existiam o salão, o bar, o quartos, as prostitutas e os amigos frequentavam juntos, mas os relacionamentos e os frequentadores eram outros. Não poderíamos classificar como motel por não ter como finalidade única a prática do sexo pago, finalidade esta de fundamental importância na diferença dos puteiros que além dela tinha outras finalidades, além de espaços de sociabilidade. Esse tipo de bordel, misto de danceteria e bar, necessita de trabalho aprofundado para especificar sua característica de mudança e sua curta duração.

Essa transição mudou muito mais do que apenas o local da prática de sexo pago - do puteiro para o motel -, ela separou, principalmente, dois tipos de representações de sociedades distintas, a europeia vitoriana, afrancesada e arejada pela Belle Époque e a americana com sua ênfase no American way of life; o glamour do sexo público, com todos os atributos que pudesse exibir, versus a racionalidade do sexo discreto, escondido, individual, aprofundado pelos ares da contracultura que debutara na década de sessenta e fizera sentir toda sua força na de setenta.

A decisão, portanto, de fechar definitivamente o "Ângelos" foi um ato arbitrário, o da anunciação da morte do Lá Hoje, idem, mas não se pode afirmar que os dois gestos foram causadores da extinção dos puteiros e lupanares na sociedade Manauara. Algo mais profundo tinha acontecido, alguma coisa que foi capaz de fazer toda uma geração deixar de seguir os costumes de seus pais e avós de irem ao puteiro e optarem pela ida aos motéis, de mudarem seus comportamentos ante o desempenho de novas práticas afetivas e sexuais que se instalava na sociedade manauara.

\subsection{A Contracultura e as Novas Representações das Práticas SeXuais.}

Criados na década de cinquenta os putanheiros da década de sessenta não conseguiram transmitir a seus filhos as mesmas normas e comportamentos que 
receberam de seus pais. Foram forjados numa cidade provinciana, dentro de uma sociedade conservadora que controlava a prática sexual impondo a abstinência sexual à moça e a virilidade ao rapaz. Ser casta e virgem era condição para o casamento da mulher, enquanto o homem, para preservar as moças casadoiras, deveriam frequentar os puteiros. Seus filhos, na década de setenta, absolvendo e tornando úteis as descobertas da década de sessenta, criaram novos hábitos, costumes e representações nas relações de afetividade que modificaram radicalmente as práticas sexuais, tanto femininas quanto masculina. Como sustenta Mary del Priore, "tudo isso não seria possível sem o poder dos meios de comunicação modernos e uma cultura de massa, capaz de difundir modelos e representações sexuais". 238

A década de sessenta apresentou diversas mudanças comportamentais em todo o mundo ocidental que afetaram de certa maneira a forma e as práticas sexuais na década seguinte, desta forma, mais uma vez houve a transferência do local da atividade prostitucional. Em Manaus, respeitando seu lugar no tempo e no espaço, os bordéis abertos denominados lupanares e puteiros deixaram de servir de local para a prostituição, aflorando os quartos de motéis como redutos do sexo pago.

Para situarmos como se processou esta mudança é necessário que se entenda alguns aspectos da estrutura social anterior à década de sessenta e as modificações ocorridas dentro dela que originaram novos comportamentos e atitudes perante o sexo e a prostituição.

O mundo ocidental até então, se pautou pela tradição judaico-cristã onde a relação sexual tinha como justificativa a procriação, de preferência dentro do casamento monogâmico e patriarcal. A mulher deveria se manter virgem até o casamento e após ele, administrar a casa, enquanto o homem tinha por obrigação prover sua mulher e filhos dentro do sagrado matrimônio. Esses papéis estavam de acordo com as diferenças biológicas sacramentadas pela religião e sancionadas pela sociedade como ordem natural. Esse pensamento definia a atividade sexual e sua imutabilidade,

Um dos temas fundamentais encontrados no pensamento ocidental, para fazer com que o código sexual moral tenha sentido, é a noção de

${ }^{238}$ PRIORE, Mary Del. Histórias íntimas. Op. cit., p. 179. 
"natureza" - uma hipótese básica no ensinamento católico romano e também de grande influência em todo o resto do Cristianismo e mesmo do Judaísmo. De acordo com essa doutrina, todas as ações têm um propósito essencial - ou natureza no jargão técnico. 0 propósito essencial de alimentar-se é sustentar a vida. 0 propósito essencial da atividade sexual é a procriação. Realizar um ato, de tal modo que seu propósito essencial - sua natureza - não possa ser preenchido é realizar um ato não natural. 239

Portar-se contrário a natureza humana era portar-se contra Deus. 0 sexo deveria ser utilizado para seu propósito - procriar -, enquanto o prazer exagerado por parte dos homens e mínimo por parte da mulher deveria ser evitado, sob pena de se estar praticando pecado. A rigidez imposta às mulheres não tinha a contrapartida com os homens, que poderiam e viviam sua plenitude sexual fora do casamento nos bordeis. Lebrun, citado por Lima, assim descreve essa ambiguidade:

essa concepção do casamento tem por consequência a coexistência de dois tipos de condutas sexuais: uma, o comportamento conjugal, que deve ser de moderação e de privação, tendo como única finalidade a procriação; outra, o comportamento extraconjugal, caracterizado pela paixão amorosa, busca de prazer para si e a infecundidade, através dos recursos anticoncepcionais. ${ }^{240}$

A sociedade ocidental desde fim da Antiguidade, tendo a religião como principal condutora agindo na superestrutura, até meados do século XX se pautou por esse paradigma em relação ao sexo. Na família não foi diferente, o amor cortês gestado no século XII, oprimindo a mulher e dando todo poder ao homem, contribuiu para o casamento burguês que possibilitou um novo tipo de família que penduraria até o final do século XX,

A família patriarcal moderna nasce assim, grávida de contradições. A
mulher já não participa da produção social, como dantes. É rebaixada à
condição de criada doméstica. E é curioso notar, de passagem, que ainda
hoje, sobre tudo nas classes médias, a dona de casa, que na realidade não
tem profissão nenhuma, está sempre pronta a responder, quando
interrogada em consultório médico, em cartório eleitoral, ou em guichê
de crediário que é "doméstica". E as chamadas "prendas domésticas"
eram joias de dotes imateriais, com que se enfeitavam as jovens de
antigamente para embebecerem noivos cobiçados. ${ }^{241}$

239 GREGERSEN, Edgar. Práticas sexuais. Op. cit., p. 13.

240 LIMA, Lana da Gama. Mulheres, adúlteros e padres. História e moral na sociedade brasileira. Rio de Janeiro: Editora Dois Pontos, 1987, p. 24.

241 FREITAS Jr., Otávio de. A prostituição é necessária. Rio de Janeiro: Civilização Brasileira, 1966, p. 12. 
Afora alguns precursores, somente após a década de cinquenta com o desenvolvimento de novos métodos anticoncepcionais e a chamada revolução feminista na década de sessenta é que se verificaram de fato mudanças significativas no comportamento sexual ocidental.

Gregenser expôs essas transformações cronologicamente, ou seja, identificando eventos que entraram em relação para a construção do novo momento: a publicação do relatório Kinsey, em 1948; a primeira cirurgia de mudança de sexo, em 1952; a descriminação dos comportamentos sexuais nos Estados Unidos, em 1955; o desenvolvimento da pílula anticoncepcional, em 1956. Em 1960, nos Estados Unidos, a pressão sobre a pornografia foi abrandada e surgiram os primeiros nus frontais em filmes. Mais o que, para muitos, fez de fato eclodir o moderno Movimento de Liberação das Mulheres foi a publicação do livro The Feminine Mystique, de Betty Friedan, em 1963.

Aliado a esse afloramento feminista, no campo político havia uma preocupação geral com o perigo da superpopulação pelos países mais desenvolvidos. Acreditavam que não haveria alimentação suficiente para todos se a população crescesse exponencialmente e a produção de alimentos não, tal como preconizava Thomas Malthus. Seus seguidores fizeram duas conferências em Lamberth, uma em 1930 e outra em 1958, onde alertavam que "não havia nada moral em permitir o nascimento de crianças destinadas a morrer em consequência de desnutrição, doenças, e outros flagelos causados pela superpopulação". ${ }^{242}$

A igreja católica, no entanto, era contrária a qualquer método anticoncepcional que não os naturais, principalmente contra o aborto. Aceitavam com reservas os preservativos e o coito interrompido, mas o ideal que ainda prevalecia era do sexo para procriação dentro do casamento monogâmico. A realidade era que, a maioria dos católicos, até a década de 1960, usava o aborto como método contraceptivo a despeito da orientação da igreja, reforçada pela encíclica do Papa Paulo VI, de 1968.

No Brasil ainda prevaleciam os comportamentos tradicionais, a virgindade era valorizada e o homem, com sua dupla vida sexual, mantinham os bordéis ainda em pleno funcionamento. As transformações, porém, vão acontecendo paulatinamente, com a educação e formação das mulheres sendo mais valorizadas, 
e o trabalho feminino fora do lar aumentando, embora ainda subsidiário ao do marido:

\begin{abstract}
A Família conjugal é o modelo dominante. Nas classes médias, a família é tipicamente nuclear com um número reduzido de filhos. Os padrões tradicionais de casamento estão com toda sua força até 1965. A autoridade máxima na família é conferida ao pai, o chefe da casa, e garantida pela legislação que incentiva o moralismo tradicional, a "procriação", o trabalho masculino e a dedicação da mulher ao lar.

A igreja católica ainda é poderosa como orientadora de conduta, mais vai perdendo terreno aos poucos para novas influências (meios de comunicação, ideias estrangeiras, emancipação feminina, educação laica etc.). De modo geral, a igreja continua apegada a concepção conservadoras (prega a submissão da esposa ao marido, e contra o trabalho feminino fora do lar e a dissolubilidade do casamento etc.), criticando duramente as diversas modificações nos costumes que vão ocorrendo na sociedade. ${ }^{243}$
\end{abstract}

No entanto as moças ainda viviam sonhando com o casamento e se preservando virgens para a noite de núpcias. Nas representações sociais da época, existiam dois tipos de moças, as de família e a leviana, enquanto o jovem era educado para ter toda liberdade sexual possível e eram incentivados a praticar sexo com as levianas. Seria demérito ante seus pares se assim não procedesse:

\begin{abstract}
os rapazes procuravam aventuras com as "galinhas ou biscates", com as quais desenvolviam todas as familiaridades proibidas com as "moças de família". Sua virilidade era medida pelo número e desempenho nessas experiências: ir a zona era preservar a menina de sociedade [...] o que o namorado não podia fazer com a namorada fazia lá. Tinha que ser lá, não podia ser com a namorada. E as meninas sabiam disso. ${ }^{244}$
\end{abstract}

Na Manaus de então, com pouco mais de 150 mil habitantes, a realidade não era diferente e o controle sobre a mulher solteira era exercido de forma firme, já que seu desleixo poderia trazer desonra para a família. Assim,

\begin{abstract}
As moças não podiam sequer sonhar em sair à noite desacompanhada. Sobre elas o controle exercido era dos mais rigorosos. Só namoram na sala ou no portão, à vista dos mais velhos. Passeio, festas, cinemas, apenas em companhia de alguém, nem que fosse de um irmão mais novo. Sozinha, nunca, porque ficava falada. E moça falada tinha reduzidas quase a zero suas chances de casamento. A virgindade era um tabu dos mais respeitados. Quando ocorria um desvirginamento, mobilizavam-se as famílias do autor e da vítima para que o caso fosse abafado e o casamento realizado sem demora. Conheci mais de um caso de marido que foi devolver a mulher aos pais, no dia seguinte ao casamento, ao constatar que havia sido ludibriado. ${ }^{245}$
\end{abstract}

\footnotetext{
243 BASSANEZI, Carla. Virando as páginas, Revendo as mulheres: Revistas femininas e relação homem mulher, 1945-1964. Rio de Janeiro: Civilização Brasileira, 1996, p. 49.

${ }^{244}$ PRIORE, Mary Del. Histórias íntimas. Op. cit., p. 166.

245 PERES, Jefferson. Evocações de Manaus. Como eu vi ou sonhei. Op. cit., p. 44.
} 
Tinham, portanto, o objetivo de casar e para isso deveria estar aptas para dirigir o lar, criar os filhos e frequentar salões. Nos estudos algumas iam além do pedagógico e entrevam na faculdade de direito. Buscavam um bom partido "que devia ser um médico, engenheiro, advogado ou oficial de uma das três armas. Se fosse também bonito e de boa família, representava, então, a encarnação do próprio príncipe encantado". 246

A mulher na década de 1960 no Brasil trabalhou arduamente para que suas metas fossem alcançadas na década seguinte. Seus primeiros passos em busca de novas representações, por exemplo, é analisada ainda em 1963 no artigo, "Garota zona sul", da revista Claudia, onde a articulista Carmem da Silva delineava algumas jovens de classe média que viviam na zona sul e tinham atitudes consideradas fora dos padrões morais por seus pais,

\begin{abstract}
Suas marcas principais são a "rebeldia contra as coisas estabelecidas", a radicalidade e a contradição. Estudam, colocam a virgindade em questão, mas são incapazes de negar enfaticamente o casamento. Criticam os casamentos que substituem "a tutela do pai pela do marido" e não suportam os rapazes "sem vida interior". Brigam constantemente com os pais, mas não saem de casa. Vão a faculdade de manhã, trabalham à tarde e saem a noite geralmente para dançar twist ou ouvir bossa-nova, ou passear de carro em busca de "experiências" ...

0 artigo reduz todo o problema da rebeldia juvenil ao relacionamento entre pais e filhos como se os padrões estabelecidos e a moral social estivessem isentos de qualquer questionamento válido ou real a ser feito com relação a estes padrões e a esta moral.

A autora nem discute questões de antes ou depois do casamento, reputação, quais homens, etc.; isto tudo tão valorizado no discurso tradicional, é secundário em sua proposta. Defende, sim, uma mudança nas estruturas e valores sociais, criticando a moral vigente e propondo uma maior liberdade-com responsabilidade para as moças e rapazes. ${ }^{247}$
\end{abstract}

Esses novos comportamento e atitudes na década de sessenta ainda eram incipientes e as representações que sustentam a moral sexual continuavam as de antes: reputação ilibada, virgindade, inocência e pureza das moças; incentivo as experiências sexuais dos homens com varias mulheres; o comportamento desviante feminino era uma ameaça a honra pessoal e familiar amparada pelo Código Civil e Penal punindo o induzimento ao erro e a anulação do casamento da noiva deflorada por outro. ${ }^{248}$

\footnotetext{
246 PERES, Jefferson. Evocações de Manaus. Como eu vi ou sonhei. Op. cit., p. 45. ${ }^{247}$ BASSANEZI, Carla. Virando as páginas, Revendo as mulheres. Op. cit., p. 201. ${ }^{248}$ Idem.
} 
Esse vínculo entre a atividade sexual anterior ao casamento e a honra feminina favorece o controle social sobre a sexualidade das mulheres que, não satisfeitas, propagam a ideia de "graduação em termos de valorização social" entre as moças de família, as levianas e, por fim, as prostitutas. "Assim do controle social da sexualidade feminina, vinculada à imposição e ao fortalecimento de códigos morais, depende a manutenção de determinadas relações de poder". ${ }^{249}$

O uso comercial da pílula anticoncepcional já na década de 1960 propiciou, juntamente com o movimento feminista e os conceitos da contacultura uma nova onda de hábitos na juventude,

\begin{abstract}
Um fato consideravelmente mais significativo que acarretou modificações no comportamento ocidental é a adoção em grande escala de métodos eficazes de contracepção, o que evita que o casamento seja limitado à produção de crianças. Em particular, o uso da pílula e também dos dispositivos intrauterinos, ambos independentes da relação sexual, tornaram possível à mulher decidir sem o conhecimento ou mesmo cooperação do homem, se desejam e quando desejam engravidar. ${ }^{250}$
\end{abstract}

A mulher passou a ter liberdade e controle sobre seu corpo, estava apta a ter relações sexuais sem o medo de engravidar, mas lhe faltava à razão, o motivo, a libertação da culpa que só viria com implementação de novos hábitos com comportamentos aceitáveis pela sua geração que engendrassem uma nova representação da mulher no mundo contemporâneo, e isso veio no bojo da contracultura.

Não existe uma origem certa para o surgimento da contracultura, "não foi um movimento com princípios e/ou programas formulados e divulgados. 0 termo foi e são usados para indicar vários movimentos da juventude nos anos 60" 251, os movimentos sociais afloraram no começo da década de 1960 em diversas partes do mundo civilizado, notadamente na França, Estados Unidos e Inglaterra. Existia o movimento hippie, o movimento pelas lutas dos direitos civis, a cultura das drogas, nos Estados Unidos o movimento contra a guerra do Vietnã, na França a reforma estudantil e outras diversas manifestações culturais entre elas o rock sua expressão máxima. Quase tudo era questionado pela onda de manifestos assim,

\footnotetext{
${ }^{249}$ BASSANEZI, Carla. Virando as páginas - Revendo as mulheres. Op. cit., p. 135.

250 GREGERSEN, Edgar. Práticas sexuais. Op. cit., p. 169.

251 PAES, Maria Helena Simões. A década de 60: Rebeldia, contestação e repressão política. São Paulo: Editora Ática, 1995, p. 22.
} 
Duas outras palavras revelam também o espírito dessa década: contestação e rebeldia. Os inconformados com o mundo em que viviam em todos os segmentos sociais e em todos os cantos do planeta, não só na Ásia e África ou na América Latina. Mas, talvez, nenhuma contestação tenha sido tão extraordinária quanto aquela realizada pela juventude. Ao lado dos hippies e dos jovens envolvidos em outras manifestações da chamada contracultura, explodia a rebelião dos "enragés", os universitários engajados nos movimentos estudantis. Pacíficos ou violentos, os jovens contestaram todas as estruturas: a capitalista e a socialistas. 0 não unia todos eles. ${ }^{252}$

Dessa maneira, Gregersen relembra que, surgiram novos estilos de vida, com comportamentos sociais mais liberais, com os jovens enganchados nesses movimentos aceitando a homossexualidade, sendo a favor do aborto, renegando a racionalidade do capitalismo, praticando o nudismo e, principalmente, aceitando a prática sexual pré-conjugal. Procuravam um mundo alternativo, e, assim, "da recusa da cultura dominante da crítica ao establishment ou sistema (como então se dizia), nasceram novos significados: um novo modo de pensar, de encarar o mundo, de se relacionar com outras pessoas" 253 . Uma nova perspectiva estava sendo gestada e num poder estatuinte que desemborcaria em novas representações.

No imaginário dos jovens manauaras a contracultura chegou pelas ondas das músicas e também mudou hábitos e atitudes: "A jovem guarda, batizada por Carlito Maia, chegou à cidade em meados da década, mas em Manaus a gente só lia a explosão do movimento nas revistas. E imitava a moda, usando calcas boca de sino, cinto calhambeque, anéis coloridos e botinha de salto" ${ }^{254}$. Esse movimento revigorado pela musica dos Beatles e pelo Maio de 1968 de Paris engendrou uma nova linguagem musical e novos padrões de comportamentos que também ecoaram na nova geração que dominaria a cidade de Manaus na década de sessenta e que destoavam da anterior. Ocorrendo inclusive o "Festival do Lixo", em 1969, realizado na paia da Ponta Negra dois meses após o de Woodstock. Os jornais registraram: "no domingo, sabe-se lá como, 20 mil pessoas se acotovelaram nas areias da praia para escutar cerca de 80 músicas, numa maratona que se iniciou às $8 \mathrm{~h}$ e terminou às $17 \mathrm{~h} 30 " .255$

\footnotetext{
252 PAES, Maria Helena Simões. A década de 60. Op. cit., p. 20.

253 Idem, p. 22.

${ }^{254}$ Amazonas em Tempo. 02.12.2010. Texto de Mário Adolfo.

255 Amazonas em Tempo. 24.01.2010. Texto de Simão Pessoa.
} 
Inegavelmente o movimento feminista desenvolveu-se nesse interim ajudando a mulher a buscar seu espaço no trabalho, nas ruas e nos quartos. A bandeira do igualitarismo chegava às margens do prazer sexual,

\begin{abstract}
Mas, o resultado mais extraordinário foi à separação entre a maior parte da atividade sexual e qualquer ideia de concepção: pelo menos em princípio, em nenhum outro momento da história da humanidade havia à disposição tanta possibilidade de sexo por e para o prazer. A mudança foi mais significativa para as mulheres do que para os homens, por causa do inescapável envolvimento das mulheres com a gravidez, mas houve implicações para ambos. ${ }^{256}$
\end{abstract}

Essas mudanças foram incentivadas pelos jornais da época, em seus suplementos culturais; na literatura médica, não só comprovou-se, como também indicou-se como desejável o orgasmo simultâneo como ideal; descriminalizou-se qualquer prática sexual, desde que causasse prazer e não envolvesse compulsão; na literatura, os livros expunham a praticidade de sexo por prazer e divertimento em detrimento daquele efetuado por amor e obrigação.

Em Manaus os ares da liberdade feminina faziam a festa dos rapazes - e das mulheres! - daquela época como bem relembra o articulista Simão Pessoa sobre o uso da Praia da Ponta negra,

Durante a semana, a praia de areia fina e água límpida (a especulação urbana ainda não havia transformado o aprazível logradouro em um esgoto a céu aberto), o simpático boteco - especializado em vender peixe frito, Cocal, Ron Merino e cerveja Xpto - e as modestas barracas de praia eram ponto de encontro quase que exclusivo de jovens bem nascidos, que possuíam condução própria, e de garotas prafrentex, disposta a ir a fundo (e bota fundo nisso) na nascente revolução cultural. Afinal ninguém ia se aventurar naquele fim do mundo apenas para ficar bebendo cachaça, olhar o rio passando e jogar conversa fora... 257

Assim a prática do sexo pré-marital passou a ser mais difundida, sem o perigo da gravidez indesejada. A mulher jovem do início da década de setenta passou a fazer sexo sem o medo de engravidar e sem o temor da rejeição do seu grupo e isso influenciou a maneira do homem jovem ver e praticar o sexo, influência essa que auxiliou na determinação de novos tipos de prostituição,

No mundo, novos padrões de prática de sexo pré-marital entre jovens e particularmente a crescente, ainda que contestado, aceitabilidade do sexo para mulheres mais jovens enfraqueceram o padrão anterior em que os rapazes eram incentivados a frequentar bordéis em busca de sua

256 STEARNS, Peter N. História da Sexualidade. Op. cit., p. 234.

257 Amazonas em tempo. Texto de Simão Pessoa. 24/01/2010. 
iniciação sexual. Nessas regiões, a ininterrupta validade da prostituição estava mais relacionada a homens de meia idade em busca de estímulo adicional fora do casamento. 258

Desta forma os bordéis não só deixaram de ser o local majoritário de iniciação sexual, mas também perderam aquele futuro frequentador que doravante praticaria sua lascívia com "mulheres faladas" e até mesmo com prostitutas, mas em outros locais, que não o bordel. Esse local, que, a princípio, e para muitos, foi o banco traseiro do carro, era o motel que, agora, além de servir para práticas prostitucionais, serviria para encontros amorosos.

\subsection{Os MotÉIS ENTRAM EM CENA.}

A utilização dos motéis como um dos locais de prática de sexo fora do casamento em substituição aos bordéis no mundo pode ser entendida como fruto das mudanças ocorrida nas décadas de sessenta e setenta no imaginário e nas representações dos jovens, como advogam determinados antropólogos, sociólogos e historiadores. 259

Para os que viveram intensamente a cultura do puteiro, os putanheiros daquela Manaus dos anos sessenta ouvidos nesta pesquisa, o "acontecido" foi de outra forma. Ou culpavam o crescimento da cidade em vista da implantação da Zona Franca de Manaus, ou alegavam melhoria nas acomodações dos motéis ou ainda uma mudança de status, como indica Joaquim: "num momento era glamoroso, dava status, o homem que frequentava era bem visto; de repente já não era mais, passou a ser démodé, cafona, passou a ser mau visto". 260

Em Manaus a troca se processou de início paulatinamente ainda na década de sessenta e se concretizou na primeira metade da seguinte, de modo que no final da década de setenta nenhum puteiro clássico havia sobrevivido.

Motel, segundo Cavalcanti, é uma palavra que surgiu nos Estados Unidos em 1925, designando um estabelecimento hoteleiro localizado nas margens das rodovias que servia para pernoite de hospedes que ainda não tinham chegado a

\footnotetext{
258 STEARNS, Peter N. História da Sexualidade. Op. cit., p. 258.

259 Podemos, a título de exemplo, citar Edgar Gregersen, na Antropologia e Peter Stearns, na História.

260 Entrevista com “Joaquim” em 15.11.2014.
} 
seu destino. Foi na aglutinação das palavras motor, posto que, chegavam geralmente motorizados, e hotel que o termo ganhou o mundo como motel. A diferenciação básica entre motel e hotel é que aquele está situado à beira das rodovias na entrada das cidades, ofereciam vagas nas garagens individuais, mas a principal diferenciação é:

\begin{abstract}
Uma segunda diferenciação se refere ao tempo de permanência dos hospedes, que seria bem menor no caso dos motéis. Esse fenômeno poderia ser justificado por duas hipóteses: a primeira, mencionada pelos construtores, donos e gerentes de motéis, seria concernente à própria localização dos estabelecimentos, os quais ofereciam apenas um local de repouso para que no visitante pudesse ali se refazer e então prosseguir sua jornada; já a segunda explicação se prenderia ao fato de que esses motéis são utilizados quase exclusivamente com o fito de programas sexuais, estando assim, a estada do hospede condicionada a duração desses encontros amorosos. ${ }^{261}$
\end{abstract}

Não é de hoje na história da prostituição que determinadas palavras deixam seu conceito original e passam a designar locais de encontro para a prática de sexo pago. Na Antiguidade foram gestadas as palavras lupanar e puta, sendo a primeira Lupanarium derivada da palavra lupae que significa loba; designação que fora usada pelas prostitutas que trabalhavam nos campos ao redor de Roma. 0 vocábulo, embora vencedor, diante da história teve como concorrente o termo fornices, que se referia aos arcos que sustentavam os edifícios públicos e no qual, no século I a.C. servia de local para as prostitutas agenciarem e até mesmo praticarem sexo entre suas colunas. ${ }^{262}$

A designação corrente e popular de puta para as prostitutas não possui uma fonte histórica que exponha com clareza sua origem etimológica. Murphy sustenta que o termo é derivado de puteus, um poço ou tanque, e que esse nome era utilizado pela tropa para designar as mulheres sobreviventes dos massacres das legiões romanas e obrigadas a servir nos lupanares militares. Por seu lado e também sem firmeza histórica, Bassermann esclarece: "sabe-se apenas que existem relações com o vocábulo latino correspondente a poço, cisterna (puteus) e que o grande escritor Plauto conferiu a uma moça de vida livre, por gracejo, uma série de nomes familiares terminados em poço do amor. Entre as muitas

261 CAVALCANTE, Lauro; Dinah Guimarães. Arquitetura de motéis cariocas: Espaço e organização social. Rio de Janeiro: Paz e Terra, 2007, p. 31.

262 MURPHY, Emmett. História dos Grandes Bordéis do Mundo. Op. cit., p. 27. 
designações romanas indicativa de prostituta, o francês, assim como outras línguas modernas de origem românica, aproveitou precisamente essa, divulgando-a". 263

Formalmente, o conceito de motel, à época, não diferia muito do exposto acima, com o Conselho Nacional de Turismo assim o classificando: "estabelecimento conhecido como motel, de hospedagem para ocupação temporária, mediante pagamento de diária, constituído de quartos mobiliados, com banheiros privativos e que ofereça garagem". ${ }^{264}$

A localização dos motéis no Brasil em principio era afastada do centro das cidades como eram anteriormente os puteiros, esse afastamento poderia ser entendido como uma busca de privacidade, anonimato ou como fuga da repressão dos órgãos. Cavalcanti assim se manifesta: "a localização dos motéis nas zonas periféricas da cidade permitia uma analogia entre o lugar geográfico onde se situam os motéis e o local do discurso sobre o sexo na sociedade mais ampla ambos situados na periferia, não muito central". 265

A repressão e o fechamento de hotéis suspeitos e rendez-vous no centro das cidades nos finais da década de sessenta pode ter contribuído para o surgimento e proliferação dos motéis nas entradas das cidades. 0 arquiteto Paulo Pontes, em entrevista a Cavalcanti, assim reporta a necessidade da criação do motel de alta rotatividade:

\section{[...] Fecharam e "quebraram" quase todos os hotéis. Aqueles que quebraram é porque foram fechados antes. Em 1969 o pessoal andava "trepando" no mato, porque não mais existia hotel algum no Rio de Janeiro para se fazer nada, fato que só veio a ser resolvido com o aparecimento dos motéis. ${ }^{266}$}

Em Manaus, na mesma época, a juventude buscava um novo local para praticar sexo e a praia da Ponta Negra nos dias de semana parecia ser o local preferido. Simão Pessoa lembra que a praia "era o grande mocó dos amantes, onde levar a paquera às novidades da praia deserta e suas possibilidades eróticas fez parte da iniciação sexual de centenas de adolescentes. Dizem que muita virgem mudou de signo ali". 267

\footnotetext{
263 BASSERMANN, Lujo. História da Prostituição. Op. cit., p. 82.

264 CNBB, Comissão episcopal da pastoral. Prostituição: desafio à sociedade e à igreja. São Paulo: Edições Paulinas. 1976, p. 155.

${ }^{265}$ CAVALCANTE, Lauro; Dinah Guimarães. Arquitetura de motéis cariocas. Op. cit., p. 39.

266 Idem.

${ }^{267}$ Amazonas em tempo. Domingo. Simão Pessoa. 24.01.2010.
} 
Se no Rio de Janeiro os motéis substituíram os hotéis suspeitos, em Manaus ele substituiu além do "rendez-vous" do centro, os puteiros periféricos, ocupando o espaço geográfico deixado por estes últimos.

Os diversos relacionamentos que ocorriam nos puteiros além do sexual, de amizade, de pertencimento, enfim, de sociabilidades, deixaram de existe com o fim dos bordéis. Em contrapartida os motéis reduziram a dois os indivíduos envolvidos diretamente em sua utilização. A busca pelo sexo passou a ser exclusiva, anônima e dual, posto que

O princípio básico nos motéis é a máxima privatização e reificação de uma ideologia individualista. Nesse tipo de estabelecimento, destinado ou não para fins exclusivamente românticos, o objetivo principal é o de fornecer a maior privacidade, isolamento e individualização dos serviços. ${ }^{268}$

Não existindo, portanto, toda a rede de relacionamentos que havia nos bordéis, que poderia ser frequentado por grupos de amigos, e onde se podia fazer novos amigos, conhecer funcionários e prostitutas e, por vezes, até o proprietário do puteiro. 0 tempo não era escasso, nem o único intuito era somente sexo. No motel o tempo é dinheiro, ao entrar o cliente já está pagando a estadia; o relacionamento é a dois, e o anonimato é a regra. Cavalcanti assim expõe:

\begin{abstract}
0 motel teria, tanto em tempo de permanência quanto no tocante a uma rede de relações, um grau bem menor de ligação com o mundo da casa. 0 período lá passado seria mínimo - durando somente o tempo de um programa sexual, constituído geralmente por algumas poucas horas, raramente chegando mesmo a um dia inteiro -, e a rede de relações foi definida como inexistente, pois haveria brevíssimo contato com, no máximo três, e às vezes somente dois, funcionários, sendo a relação unicamente estabelecida entre os próprios parceiros. ${ }^{269}$
\end{abstract}

Nos puteiros os intercursos eram abertos e com diversas opções podia-se escolher ficar bebendo sozinho, dançando com as prostitutas, conversando com amigos ou fazendo sexo. Circulava-se com desenvoltura pelo salão, pelas piscinas, entre as mesas, nos estacionamentos, conversava-se com os choferes de praça, garçons e podia-se até "brechar" o amigo fazendo sexo.

No motel o itinerário é fixo, já que ao chegar a um motel o cliente solicita o quarto da recepcionista que lhe entrega a chave do apartamento ou suíte, passo seguinte você entra na garagem individualizada e após estacionar fecha a garagem

268 CAVALCANTE, Lauro; Dinah Guimarães. Arquitetura de motéis cariocas. Op. cit., p. 47.

269 Idem, p. 62. 
para não ser reconhecido por ninguém, entra no quarto e solicita a telefonista serviço de bar e restaurante, o garçom lhe entrega na "boqueta" ou coloca na antessala seu pedido, faz sexo, pede a conta, paga, dirige-se para a saída e sai. ${ }^{270}$

Ao contrário da maioria dos bordeis, os motéis tinham por proprietários empresários que nem sempre gerenciavam seu empreendimento. Procuravam inovar para atrair fregueses. Predecessores dos hotéis suspeitos, os motéis procuraram otimizar o espaço e o tempo e, assim

[...] é possível estabelecer as modificações que foram ocorrendo nesses estabelecimentos, a partir de sua implantação, no final da década de 1960, até sua estrutura nos anos 1980. Uma primeira transformação refere-se à retirada dos armários, peças obrigatórias nos quartos dos hotéis suspeitos do inicio dos anos $1960 \ldots$ visava caracterizar a não rotatividade, dando a impressão de que o hóspede ia passar dias. ${ }^{271}$

No local do armário passou a ser exposto nas paredes um nicho com alguns cabides para pendurar calças blue jeans, camisas Hering e outras roupas, sem a preocupação do vinco do tecido, como acontecia com a geração anterior.

Para Cavalcanti a introdução do espelho, do som de radio com canais e por fim a televisão foram outras inovações que formaram o complexo do quarto do motel onde reinava impoluta a cama. 0 espelho chegou devagar, pelos lados como a servir a mulher no arranjar das madeixas e não encabular o "sujeito que ainda tinha medo de assumir o corpo. Estava ele começando a entender que sexo era uma coisa como comer, viver" ${ }^{272}$. A utilização do radio com diversos canais, além de dar um toque romântico com musicas como "Je t'aime, moi non plus", "Café da manhã" e outras dos gêneros, serviam também para atualizar o homem sobre jogos de futebol e permitia que quando chegasse em casa, pudessem disfarçar da mulher onde estivera, comentando os lances dos jogos como se lá estivesse. A utilização da televisão tinha fins afrodisíacos, utilizava o sistema de vídeo cassete e filmes estrangeiros.

Mais o palco, o ringue, o altar para o sacrifício do amor, a peça mais importante no motel era a cama. No principio era comum como a de qualquer quarto, passando a ter 1,80 de largura por 1,80 de comprimento para atender todo tipo de posição e ser feito de cimento para não ranger e aguentar qualquer peso.

\footnotetext{
${ }^{270}$ CAVALCANTE, Lauro; Dinah Guimarães. Arquitetura de motéis cariocas. Op. cit., p. 74.

271 Idem, p. 106.

272 Idem, p. 112.
} 
Nela fora anexado o telefone e um painel de controle para maior conforto dos usuários. Para um homem que frequentava puteiros acostumado com a cama de madeira, a penteadeira ou mesa e a bacia para o banho, ver toda aquela parafernália e todo aquele conforto era espantoso.

O primeiro motel que se tem notícia na cidade de Manaus é o que nos é relatado pelo memorialista Oyama Ituassú:

\begin{abstract}
Nessa década (1960) surgiu o primeiro motel da cidade. "Os Sete Anões", localizado onde hoje está construída a fábrica da Philips. Eram sete casinhas, no estilo do conto infantil, pintadas de cores diferentes. Lá se podia ir de automóvel, devido à distancia. Não demorou muito a desaparecer, tragado pelo desenvolvimento repentino da Capital, que absorveu os recantos diversionistas. ${ }^{273}$
\end{abstract}

As características de um motel já estavam ali desenhadas, instalado numa rodovia, chegada de automóvel e quartos individuais, embora nem todos os posteriores tenham se estabelecido na única rodovia de então, a AM 010. Mais se os Sete Anões foi o primeiro motel, não se pode dizer que fora a primeira tentativa de achar um local para prática de sexo pago. Outro memorialista nos informa de como se resolvia o problema de local para a prática do sexo na cidade:

O problema com elas podia ser o local de encontro, a menos que o
interessado fosse locatário de um pequeno apartamento ou tivesse
amigo que cedesse a chave de algum. E sempre havia no grupo dois ou
três que, em sociedade com outros, mantinham garçonières em velhos
edifícios do centro. Quando não aparecia esse quebra-galho, e se havia
algum dinheiro no bolso, podia-se ir a uma casa especializada. Ainda não
havíamos ingressado na era dos motéis, mais existiam seus precursores
os rendez-vous, dos quais o mais procurado e acessível era a Pensão Ritz.
Pertencia a Flora Lifsitch que recebia o pagamento deitada numa rede, e
invariavelmente perguntava se a moça era virgem, temerosa de
complicação com a vara de menores. A seguir o casal era encaminhado
para um dos quartos, verdadeiros cubículos, divididos por tabique, com a
tradicional cama de ferro no centro. Desconfortáveis e poucos asseados,
nem por isso a procura diminuía. Às vezes era preciso esperar na fila. ${ }^{274}$

Pode parecer estranho Péres colocar os rendez-vous como predecessor dos motéis, pulando os puteiros e lupanares, o que se pode inferir é que ele se referia ali como um jovem de parcos recursos na década de cinquenta, com uma mulher para praticar sexo e sem local específico para tal. Talvez se tivesse carro, poderia ter ido ao Bom futuro. Outra informação é que apesar de não ter ainda ingressado na era dos motéis, o modus operandi já dava contornos do que seria oferecido nos

273 ITUASSÚ, Oyama Cesar. Memórias do meu tempo. Op. cit., p. 73.

274 PÉRES, Jefferson. Evocações de Manaus. Como eu vi ou sonhei. Op. cit., p. 155. 
motéis da década de setenta - quartos individualizados, mulheres trazidas de fora, embora sem oferecer garagem, além de estar estabelecida na zona urbana.

Para os putanheiros a lembrança de onde se instalou o primeiro motel foi na estada do Aleixo e chamava-se Motel Rip, pertencendo ao irmão do governador Gilberto Mestrinho. Outro motel citado como primogênito foi o Villasge Motel (ou Vilas Motel), misto de hotel e motel, existente "perto da faculdade de medicina, a gente pegava as meninas e levava para ali, a gente fazia fila pra "foder" 275 . Depois destes, na década de setenta outros surgiram, o "Motel London" e o "Chateau motel" na estrada do Conjunto Petro, e, por causa deles, popularmente conhecida como Rua dos motéis; o "Você que sabe", também na estrada do Aleixo; o "Detalhes Motel", na AM 010; o "Cobras Motel", na Djalma Batista, o "Motel Ok" na mesma rodovia, o "Motel Le Baron", na estrada do V8, enquanto na compensa existia o "Motel Del Rey". Todos na periferia de Manaus.

Poucas imagens dos motéis surgem nas lembranças da maioria dos putanheiros, mesmo quando são incitados a falar sobre o assunto são monossílabos, definem a mudança de modo simplório, sem se ater a grandes hipóteses "no puteiro você dança, você tem vários amigos e depois sai da sua mesa consagrada e vai para o quarto. Já no motel você pega a menina na rua já vai direto sozinho" 276. Como se o tempo e a pouca intimidade fizessem toda a diferença; outros fixavam a mudança no ambiente físico: “a diferença é que você levava até água para se lavar, não tinha nem banheiro, e o motel tinha..." 277; mas a maioria via na ausência da sociabilidade a transformação (e perda) maior:

A diferença entre os puteiros e os motéis. Aqueles eram como um clube, o puteiro você passava a noite, era bem melhor, dançava e tal, quando eu não estava de plantão eu virava, saia sexta feira e voltava domingo, passava o dia todinho com a menina e dormia. Sábado de manhã ficava no quarto bebendo e comendo no Verônica. ${ }^{278}$

Essa comparação com um clube social se repetem em outras entrevistas, e assim, quando Ricardo se referia a locomoção das prostitutas, definia o espaço: “Elas não moravam nos puteiros, elas vinham de vários locais, se reuniam lá como

\footnotetext{
275 Entrevista com Chicão, 26/07/12.

276 Entrevista com Ricardo, 26/07/12.

277 Entrevista com "Heleno", realizada em 05.11.12.

278 Entrevista com "Joaquim", realizada em 11.10.3.
} 
um clube e os clientes iam né..." essa identidade servia, inclusive para diferenciar as prostitutas de outras mulheres como nos recorda W., em sua entrevista

\begin{abstract}
Mais era uma época muito boa a gente sabia que toda mulher que tava ali era puta, hoje você não sabe. Eu tenho muita saudade daquela época. A diferença é que o puteiro em si a gente tomava por base como sendo aquela sede que a gente dançava e os quartos que estavam a disposição dos frequentadores, diferente dos motéis... a tempo bom. ${ }^{279}$
\end{abstract}

Outros ainda, sem grande esforço intelectual, constatavam o resultado das transformações sociais que influenciaram a decadência dos puteiros como o gerente do último puteiro a fechar os quartos,

Era muito legal. Você se divertia com os amigos, bebia e comia as putas, tudo num lugar só, muita das vezes ainda tomava banho. "O Piscina Clube" era o melhor puteiro de Manaus.

Acabou, quem sabe bem é o papai, mas eu acho que as meninas começaram a dar para os namorados, os rapazes deixaram de ir lá e as putas rarearam... Eu não tenho muita certeza. 280

De fato as prostitutas, como aquelas que vivenciam a lembranças desses putanheiros, rarearam a ponto de, praticamente, não existir mais nenhuma; transformaram-se todas em "garotas de programa", incorporando outros modos de fazer sexo e buscando outras expectativas; As virgens também sumiram, na praia da Ponta Negra ou nas ruas desertas do distrito industrial, desaguando nos quartos modernos dos motéis.

Não havia mais espaço para os banhos nos igarapés santificados de Eros, ou melhor, de tanatos freudiano, nem para a conversa fiada entre amigos, regado por um copo de Antártica ou Romerino, a espera que a libido chegasse entre as pernas apetitosas das prostitutas escorregadias num bolero. Não, aquilo deixara de existir! Agora era somente ele e ela num sofisticado e frio quarto de motel.

Neste capitulo discutimos a transferência do local da prática do sexo pago dos puteiros e lupanares para os motéis. Vimos como aparentes perseguições aos puteiros pela imprensa e por órgãos oficiais poderia ser entendido como causa de extinção, se não tivéssemos percebido toda uma mudança de representações que num processo constituinte criassem um novo imaginário no homem da década de setenta do século passado. Esse novo imaginário, que se originou no bojo da contra cultura e na libertação feminina, deu a mulher, em geral, uma liberdade de corpo e

279 Entrevista com "Willes", realizada em 26.07.12.

280 Entrevista com "Fabio", realizada em 23.06.2013. 
de mente, que propiciaram relações sexuais pré-nupciais com mais frequência e sem culpa, retirando dos bordeis os rapazes e, portanto, privando do puteiro um novo freguês. Por outro lado surgem os motéis oferecendo abrigo e sofisticação para os antigos relacionamentos prostitucionais e para esses novos, envolvendo homem e mulher, mas não necessariamente a prostituta. 


\section{CONSIDERAÇÕES FINAIS}

Percorrendo a existência dos bordéis manauaras, desde seu debut nas "casas de pensões" até os últimos "rendez-vous" popularmente chamado de puteiros e lupanares, nos deu a sensação que houve mais permanências que transformações, o que não se pode dizer quando da transferência dos puteiros e lupanares para os motéis. Aqui a transformação foi radical, quase uma ruptura geral de valores, atitudes, modos de pensar e praticar o sexo.

Ao concluirmos essa pesquisa, amparado pela memória dos putanheiros e o imaginário dos homens da década de sessenta, poderíamos eleger duas conclusões que se sobressaíram no decorrer da pesquisa: primeiro a especificidade dos igarapés como componente do complexo arquitetônico dos puteiros e lupanares; segundo a profunda mudança que ocorreu na passagem da década de sessenta para a década de setenta em toda a estrutura da sociedade manauara que talvez tivesse influenciado a extinção dos puteiros na cidade.

O homem amazônico para sobreviver ao forte calor e a alta umidade sempre se valeu da grande quantidade de água existente ao seu redor, não só para se reidratar, mas também para refrescar seu corpo, já sendo assim muito antes mesmo dos europeus aqui chegarem. Tem a sua disposição algumas praias ao longo dos grandes rios, mas são as margens de igarapés que procuram para banhar-se e quase sempre acompanhado de pessoas afins. Não era de admirar-se que ali se constituísse uma rede de sociabilidade. Manaus até a década de setenta possuía diversas bacias hidrográficas constituídas de igarapés límpidos e que com o advento da grande urbanização foram poluídos, soterrados ou servem de esgotos.

Os "puteus" eram locais que abasteciam de água as cidades hebreias na antiguidade e foram neles que as mulheres públicas se estabeleceram; os bordéis gregos se localizavam ao redor de locais de grande concentração humana, assim foram os portos de Corinto e a Ceramicus, em Atenas; os lupanares que se espalharam pelo mundo graças às centúrias romanas, se estabeleciam perto das tropas. Assim, nada mais lógico que os puteiros e lupanares da cidade de Manaus 
da década de sessenta se estabelecessem em locais que possibilitassem, além do sexo, outros espaços de lazer e sociabilidade.

Os igarapés já serviam de locais para outras relações sociais, e dele as lavadeiras já faziam uso há tempos, tanto quanto os aguadeiros e os catraieiros. Mesmo as famílias os procuravam nos fins de semana, oportunizando suas águas límpidas para se refrescar e suas margens para promoverem piqueniques, como relata um importante memorialista:

\begin{abstract}
A natação era praticada mesmo, em grande escala, como lazer, nos balneários, ou banhos, dos arredores da cidade, e até nos igarapés do centro, como o da primeira e segunda ponte, bem como o de São Vicente. Os balneários eram muitos, como a Pomerânia, a Chapada Síria, o V-8, o igarapé do 40, o então distante Tarumã, e principalmente, acima de todos, o Parque 10 de Novembro do igarapé do Mindu. Era o ponto de encontro da população, nas manhãs de domingo, quando ficava cheio de casais, mulheres bonitas e crianças, num ambiente puramente familiar. $^{281}$
\end{abstract}

Era por excelência um centro de sociabilidade numa cidade considerada por seus moradores como cidade balneária, nos bairros periféricos surgiam trilhas que levavam aos igarapés para construir cacimba e arrumar tábuas para lavar roupa: "as mulheres eram auxiliadas pelas crianças tanto na lavagem de roupa quanto no transporte de água e lenha". Vai mais além o olhar do geógrafo, que nos informa:

Os igarapés e os vales se constituíam como locus preferencial do
entretenimento que se caracterizava pelo espaço de uso, predominando
sobre o espaço de troca. Neste sentindo, os igarapés eram lugares de
referência que simbolizavam parte do cotidiano, presença concreta e
possibilidade de encontro. ${ }^{282}$

Não foi à-toa que o balneário Bom futuro em meados da década de cinquenta deixou de ser familiar e passou a ser o primeiro puteiro da cidade, aproveitando dois locais de sociabilidade e juntando-os num só, dando a este tipo de bordel característica única.

Os igarapés que banhavam os puteiros tinham suas margens cercadas de tábuas de um lado e de outro, com uma ou duas escadas que serviam para sair da piscina ou ficar sentado bebendo, conversando ou namorando, como qualquer outro banho de então, exceto por estarem encravados dentro do complexo prostitucional.

281 PÉRES, Jefferson. Evocações de Manaus. Como eu vi ou sonhei. Op. cit., p. 168.

282 OLIVEIRA, José Aldemir. Manaus de 1920-1967. Op. cit., p. 148. 
Os banhos orgíacos que povoavam o imaginário dos não putanheiros, notadamente o das mulheres direitas, pouco ou nenhuma informação confiável atestam suas realizações embora veladamente seja insinuada. 0 que foi relatado era que no Bairro da Cachoeirinha,

\begin{abstract}
Havia quatro banhos muito frequentados: do Quarenta, da Raiz, da Bacia e da Pancada. Falava-se também do Crespo e do Japiim. Quarenta e Raiz ficavam distantes, em plena mata, por isso mesmo considerados perigosos. Lá se reuniam os boêmios e mulheres andejas em busca de aventuras. [...] A Bacia distinguia-se pela forma realmente arredondada, em meio à compacta vegetação. Diziam os antigos que era o ponto preferido pelas "hetairas das pensões alegres" 283
\end{abstract}

Pelo acima descrito infere-se que mesmo antes do surgimento dos puteiros e lupanares os igarapés já tinham esporadicamente servido de local de prática prostitucional.

A outra conclusão foi à abrupta e profunda modificação que ocorreu nas estruturas da sociedade manauara no decorres da passagem da década de sessenta para a década de setenta. Não elegemos suas possíveis causa, não é o caso deste trabalho, mais algumas consequências e constatações que influenciaram a mudança nas práticas sexuais e que deixaram estatelados os putanheiros da década de sessenta.

Como anteriormente exposto, a contracultura trouxe em seu interior diversas manifestações de grupos minoritários, até então sem ou com pouca voz, que aproveitando o eco da crescente mídia conseguiu impor sua cultura, preferência, raça e gênero, onde floresceu "a cultura jovem dos anos 60 foi extremamente sensível e simpática a toda e qualquer movimentação de grupos étnicos ou culturais que se vissem nessa posição de marginalidade ou exclusão diante a sociedade ocidental". ${ }^{284}$

Nesse sentindo, as manifestações pelos direitos dos negros nos Estados Unidos durante toda década; pelo Movimento da Liberação das Mulheres, a partir de 1963; à favor do Movimento da liberação Gay, desde 1969; a eclosão filosófica e estudantil na França ${ }^{285}$, tudo isso colocou em questionamento o "Establishment" predominante no mundo ocidental. 0 movimento passou então a ter o caráter de conflito familiar,

${ }^{283}$ MATA, João Nogueira. Amazônia terra da promissão. Op. cit., p. 42.

${ }^{284}$ PEREIRA, Alberto M. O que é contracultura. São Paulo: Brasiliense, 1983, p. 42.

285 GREGERSEN, Edgar. Práticas sexuais. A história da sexualidade humana. Op. cit., p. 164. 


\begin{abstract}
A partir de um certo momento começou a ser cada vez mais frequente e comum o emprego, em contextos diversos, da expressão conflito de geração. Falar então de conflito de geração era tocar em um problema essencialmente político. Não se tratava mais de um fenômeno episódico e particular, mais de um foco importante de contestação social da época. o espaço privado e íntimo da família - palco por excelência desses conflitos - ganhava ares de arena politica. Houve quem dissesse que a "revolução" havia chegado às salas de visita de algumas das mais pacatas famílias burguesas ou mesmo sentado à mesa do jantar. ${ }^{286}$
\end{abstract}

Em Manaus esse conflito se manifestou de imediato em alguns setores, houve um festival de música ao modo de Woodstock, o consumo do Rock como música preferida da juventude aumentou, as roupas, os cabelos compridos e principalmente hábitos e comportamentos que batiam de frente com a moral da sociedade manauara.

Dos movimentos desencadeados em nível mundial o que interessou nesse trabalho foi o do Movimento de Liberação da Mulher. Nele, toda uma prática sexual exercida há décadas foi posta do avesso, questionada em toda a sua estrutura. Vimos que esse movimento juntamente com métodos contraceptivos propiciou a mulher maior liberdade sexual, se um libertava a mulher da culpa da prática sexual antes do matrimônio, a outra lhe dava a opção de fazer sexo sem o medo de uma gestação não desejada.

Em Manaus no fim da década de sessenta essa liberação começou a se fazer sentir e algumas jovens pioneiras - chamadas de prafentex - passaram a ter atividade sexual antes do casamento. Os rapazes passaram a ter outra opção sexual antes de casar que àquela ida aos puteiros. A princípio praticavam sexo nos carros em ruas desertas, na Praia da Ponta Negra e em alguns igarapés nas altas horas, para posteriormente se aconchegarem nos nascentes motéis.

Essas mudanças de comportamentos foram recebidas pela geração anterior como sinônimo de imoralidade, depravação, e com "o aumento desordenado da população, o surgimento da Zona Franca, a implantação de indústrias, o surgimento da televisão, tudo propiciou a brutal derrocada das instituições então validas" 287. Péres trouxe uma visão mais concisa ao perceber o surgimento do movimento na cidade: "Quando veio a nova onda a cidade, valente de brios, resistiu até onde pôde, aos furores de uma dominação cultural que acabou por submetê-la

286 PEREIRA, Alberto M. O que é contracultura. Op. cit., p. 25.

287 ITUASSÚ, Oyama Cesar. Memórias do meu tempo. Op. cit., p. 209. 
com os ímpetos do capital sem-nação e com as suavidades do engano colorido da comunicação de massa totalizadora". 288

Já os putanheiros, sem grandes doses filosóficas, assinalam alguns lampejos de compressão e acatamento sobre as transformações, principalmente em reação a extinção dos puteiros: "foi o progresso que acabou com tudo" 289; "a modernidade mudou tudo e também acabou com os puteiros" 290; "as moças passaram a dar para seus namorados, sem cobrar nada [...] davam por que queria ai os homens passaram a querer só elas, era mais gostoso e barato" 291.

Mas uma fala, em meio aos depoimentos merece uma reflexão maior, que ainda agora me preparo para fazer. Ela foi dada por um senhor que estava junto com o entrevistado A. P. na última entrevista que realizamos. No momento não indaguei seu nome e, hoje, acho que foi melhor assim. Ele simplesmente falou, interrompendo a entrevista: "Os puteiros se extinguiram porque nós envelhecemos"!

Talvez seja isso.

\footnotetext{
${ }^{288}$ PÉRES, Jefferson. Evocações de Manaus. Como eu vi ou sonhei. Op. cit., p. 168.

289 Entrevista com "Altair", realizada em 28.12.2013.

290 Entrevista com "Rogério", realizada em 13.12.2014.

291 Entrevista com “Carlos", realizada em 05.06.1999.
} 


\section{REFERÊNCIAS}

\section{1 - Depoentes ${ }^{292}$ :}

APS (Altair) 23.07.2012. 80 anos. Putanheiro. Prefeito, funcionário público, hoje aposentado.

RGA (Roberto) 15.06.2012.72 anos. Putanheiro. Na época funcionário público. Hoje aposentado.

RGA (Roberto) 10.06.2012. Idem

JAB (Joaquim) 11.10.2012. 74 anos. Putanheiro. Militar da aeronáutica. Hoje aposentado.

RC (Ricardo) 26.07.2012. 65 anos. Putanheiro. Barnabé. Hoje aposentado.

FBR (Fabricio) 04.12.2012. 66 anos. Putanheiro. Jornalista. Fotógrafo aposentado.

HAM (Heleno) 03.12.2012. Putanheiro. Motorista de praça. Hoje proprietário de oficina.

HAM (Heleno) 05.11.2012. Idem.

WFA (Antônio) 15.06.2012. 73 anos. Frequentador. Na época comerciante. Hoje aposentado.

CM. (Carlos) 05.06.2005. Motorista de praça. Falecido.

BA. (Barbara) 12.09.2011. 80 anos. Mulher de putanheiro. Dona de casa. Dona de casa.

WC (William) 15.06.2012. 63 anos. putanheiro e frequentador de motel. Contador. Aposentado.

FM (Fábio) 23.06.2013. 59 anos. Gerente de puteiro. Dono de estacionamento.

M.P. (Mateus) 28.06.2013.83 anos. Proprietário de puteiro. Hoje Comerciante.

DFS. (Dorotéia) 30.07.2013. 66 anos. Irmã e filha de putanheiro. Moça. Aposentada.

M.M.(Paraense) 15.08.2013. 57 anos. Jogador de futebol. Comerciante.

\section{2 - Periódicos:}

A Crítica, 1959/1969

A Gazeta, 1959/1963/1964

A Notícia, 1969.

Jornal do Comércio, 1959.

Amazonas em tempo, 2010.

\footnotetext{
${ }^{292}$ Utilizado na dissertação nomes fictícios.
} 


\section{3 - Referencias Bibliográficas:}

ADLER, Laure. Os Bordéis Franceses, 1830-1930. São Paulo: Cia das Letras, 1991.

AGUIAR, José Vicente de Souza. Manaus praça, colégio e cinema anos 50 e 60 . Manaus: Edições Governo do Estado do Amazonas, 2002.

BASSANEZI, Carla. Virando as páginas, Revendo as mulheres. Revistas femininas e relação homem mulher 1945-1964. Rio de Janeiro: Civilização Brasileira, 1996.

BASSERMANN, Lujo. História da Prostituição: Uma Interpretação cultural. Rio de Janeiro: Civilização Brasileira, 1968.

BITTENCOURT, Agnello. Fundação de Manaus: pródromos e sequências. Manaus: EDUA, 1999.

BLANC, Claudio. Uma breve história do sexo. São Paulo: Editora Gaia, 2010.

BOSI, Ecléa. Memória \& sociedade: lembrança de velhos. São Paulo: T. A. Editor, 1979.

BOURDIEU, Pierre. A dominação masculina. Rio de Janeiro: Bertrand Brasil, 1988.

BRESCIANI, Maria Stella Martins. Lógica e dissonância - Sociedade de trabalho: lei, ciência e resistência. In: FENELON, Déa Ribeiro. Sociedade e trabalho na História. Revista Brasileira de história volume 6, no 11. São Paulo: Marco Zero, 1985.

CARDOSO, Elizangela Barbosa. Identidade de gênero, amor e casamento em Teresina. (1920-1960). Tese de doutorado em História. Niterói: UFF, 2010.

CAVALCANTE, Lauro; Dinah Guimarães. Arquitetura de motéis cariocas. Espaço e organização social. Rio de Janeiro: Paz e Terra, 2007.

CHARTIER, Roger. “O Mundo Como Representação”. Estudos Avançados, 11 (5), 1991.

CHARTIER, Roger. À Beira da falésia: A história entre certezas e inquietudes. Porto Alegre. Ed. Universidade/UFRGS, 2002.

CHARTIER, Roger. Cultura Popular: Revisitando um conceito historiográfico. Estudos Históricos, vol. 8, no 16 (1995), 179-182.

CONFERÊNCIA Nacional dos Bispos do Brasil. Comissão Episcopal de Pastoral. Prostituição desafios à sociedade e à igreja. São Paulo. Edições Paulinas. 1976.

COUTINHO, Carlos Augusto. Manaus, aspectos históricos e culturais. Manaus, 2006.

PRIORE, Mary Del. Histórias íntimas: Sexualidade e erotismo na história do Brasil. São Paulo: Planeta do Brasil, 2011.

FERREIRA, Márcio Alexandre Moreira. O desenvolvimento do capitalismo em Manaus. Manaus: SEC/EDUA, 2003.

FIGUEREDO, Aguinaldo Nascimento. Bairro de Santa Luzia - História e memória do povo do Emboca. Manaus: Edições Muiraquitã, 2010.

FIORENTI, Mariana Cunha Ferrari. Vila Palmira - prostituição em Florianópolis e São José (1960 - 1980) In: FÁVERI, Marlene; SILVA, Janine Gomes e PEDRO, 
Joana Maria (Orgs.). Prostituição em áreas urbanas História do tempo presente. Florianópolis: Editora UDESC, 2007.

FONSECA, Guido. História da prostituição em São Paulo. São Paulo: Resenha Universitária, 1982.

FORTES, Alexandre. Negro, Luigi e Fontes, Paulo. Peculiaridade de E.P. Thompson. In: THOMPSON, E. P. As peculiaridades dos ingleses e outros artigos. São Paulo. Unicamp. 2002.

FOUCAULT, Michel. História da Sexualidade. Rio de Janeiro: Graal, 1979.

FREIRE, José Ribamar Bessa. Barés, Manáos e Tarumãs. Amazônia em cadernos, vol. 2/3. Manaus: EDUA, 1994.

FREITAS Jr. Otávio de. A prostituição é necessária? Rio de Janeiro: Civilização Brasileira, 1966.

FREITAS, Renan Springer de. Bordel, bordéis: Negociando identidades. Petrópolis: Vozes, 1985.

FREITAS, Sônia Maria de. História oral: Possibilidades e procedimentos. São Paulo: Associação Editorial Humanitas, 2006.

GORDON, Richard. A Assustadora história do Sexo. Rio de Janeiro: Ediouro, 1997.

GREGERSEN, Edgar. Práticas sexuais. A História da sexualidade humana. São Paulo: Livraria Roca, 1983.

HUNT, Lynn (Org.). A Nova História Cultural. São Paulo: Martins Fontes, 1992.

LAGENEST, H. D. Barruel de (Org.). Lenocínio e prostituição no Brasil. Rio de Janeiro: Agir, 1960.

LARGMAN, Esther. Jovens polacas: Da miséria na Europa à prostituição no Brasil. Rio de Janeiro: Sindicato Nacional dos Editores de Livros, 2007.

LIMA, Claudio de Araújo. Pequena história do sexo ocidental. Rio de Janeiro: Civilização Brasileira, 1961.

LIMA, Estácio. Prostituição tragédia humana. In: Lagenest, H. D. Barruel de (Org). Lenocínio e prostituição no Brasil. Rio de janeiro. Rj. Agir Editora. 1960.

LIMA, Lana da Gama. Mulheres, adúlteros e padres: História e moral na sociedade brasileira. Rio de Janeiro: Editora Dois Pontos, 1987.

LÍVIO, Tito. História de Roma: Ab urb condita libri. São Paulo: Paumape, 1995.

MARTINS, Suely Aparecida. "As Contribuições Teórico-metodológicas de E.P. Thompson: experiência e cultura”. In: Revista Eletrônica dos Pós-Graduandos em Sociologia Política da UFSC. Vol.2 no 2 (4), ago-set/2006. Santa Catarina.

MATA, João Nogueira da. Amazônia: Terra da promissão. Manaus: Gráfica Rex, 1979.

MATTÉ, Aline Karem. Prazeres velados e silêncios suspirados. Sexualidade e contravenção na região colonial italiana. (1920-1950). Dissertação de mestrado. Porto Alegre: PUC-RS, 2008.

MELLO, Lucius de. Eny e o grande bordel brasileiro. Rio de Janeiro: Objetiva, 2002. 
MELLO, Thiago de. Manaus, amor e memória. Rio de Janeiro: Philobiblion, 1984.

MENEZES, Lená Medeiros de. Os estrangeiros e o comércio do corpo nas ruas do Rio de Janeiro (1890-1930). Rio de Janeiro: Arquivo Nacional, 1992.

MURPHY, Emmett. História dos Grandes Bordéis do Mundo. Porto Alegre: Artes e Ofícios, 1994.

NONATO, Áureo. Os bucheiros: Um memorial de infância. 3aㅡ edição. Manaus: Valer, 1997.

NOVAES, Carlos Eduardo e César Lobo. Sexo para principiantes: Da idade das cavernas à era dos motéis. São Paulo. Editora Ática. 2003.

OLIVEIRA, José Aldemir de. Manaus de 1920-1967: A cidade doce e dura em excesso. Manaus: Valer; EDUA, 2003.

ORUN, T. Thomas. As mulheres das portas abertas: judias no submundo da Belle Époque amazônica, 1890-1920. Manaus: Revista Estudos Amazônicos. Vol.VIII, no 1 (2012).

PAES, Maria Helena Simões. A década de 60: Rebeldia, contestação e repressão política. São Paulo: Editora Ática, 1995.

PASINI, Elisiane. Os homens da Vila: Um estudo sobre relações de gênero num universo de prostituição feminina. Tese de Doutorado. Campinas: UNICAMP, 2005.

PEREIRA, Armando. Prostituição: Uma visão global. Rio de Janeiro: Pallas, 1976.

PEREIRA. Alberto M. O que é contracultura. São Paulo: Editora Brasiliense, 1983.

PÉRES, Jefferson. Evocações de Manaus como eu vi ou sonhei. Manaus: Valer, 2002.

PERROT, Michelle. Os excluídos da história: Operários, mulheres, prisioneiros. Rio de Janeiro: Paz e Terra, 1992.

PINHEIRO, Maria Luiza Ugarte. A cidade sobre os ombros: Trabalho e conflito no porto de Manaus, 1899-1930. Manaus: EDUA, 2003.

PORTER, Roy e Rousseau, G. S. Submundo do sexo no iluminismo. Rio de Janeiro: Rocco, 1999.

RAGO, Margareth. Os prazeres da noite: Prostituição e códigos da sexualidade feminina em São Paulo (1890-1930). Rio de Janeiro: Paz e Terra, 1991.

RICHARDS, Jeffrey. Sexo, desvio e danação: As minorias na Idade média. Rio de janeiro: Jorge Zahar Editor, 1993.

RIOUX, Jean-Pierre; SIRINELLI, Jean-François (Orgs.). Para uma História Cultural. Lisboa: Editorial Estampa, 1998.

SALLES, Catherine. Nos submundos da Antiguidade. São Paulo: Brasiliense, 1982.

SANTOS JUNIOR, Paulo Marreiro dos. Pobreza e prostituição na Belle Époque manauara. 1890-1917. Revista de História Regional. 10.02 87-108. Inverno. 2005.

SARGES, Maria de Nazaré. Belém: riquezas produzindo a Belle Époque (1870-1912). Belém: Paka-Tatu, 2010. 
SARLO, Beatriz. Tempo passado. Cultura da memória e guinada subjetiva. São Paulo: Companhia das Letras, 2007.

SERRA, Celso Luiz Rocha. Cruz, Wilson Rodrigues da. Aspectos econômicos e sociais da Cidade Flutuante. Manaus: Gráfica Amazonas, 1964.

SILVA, Jean Carlos da. O conceito de território na geografia e a territorialidade da prostituição. In. Ribeiro, Miguel Ângelo (Org). Território e prostituição na metrópole carioca. Rio de Janeiro: Ecomuseu Fluminense, 2002.

SILVA, José Lopes. Amazonas: do extrativismo à industrialização. Manaus: Editora Valer. 2011.

SOARES, Luiz Carlos. Rameiras, ilhoa, polacas: A prostituição no Rio de janeiro do século XIX. São Paulo: Ática, 1992.

SOUZA, Leno José Barata. Eva, vadios e moleques. In: Canoa do Tempo, Manaus, n $1^{\text {o }}$ 2007.

STEARNS, Peter N. História da sexualidade. São Paulo: Contexto, 2010.

TAYLOR, Timothy. A Pré-história do Sexo: quatro milhões de anos de cultura sexual. Rio de Janeiro. Campus, 1996.

THOMPSON, E. P. Costumes em Comum: Estudos sobre a cultura popular tradicional. São Paulo: Cia das Letras, 2002.

THOMPSON, E.P. As Peculiaridades dos Ingleses e outros artigos. São Paulo. Unicamp. 2002.

THOMPSON. E.P. A Miséria da Teoria ou um planetário de erros: uma crítica ao pensamento de Althusser. Rio de Janeiro: Zahar, 1981.

VIDAL-NAQUET, Pierre. Os Assassinos da Memória: “Um Eichmann de Papel” e outros ensaios sobre o revisionismo. Campinas: Papirus, 1988.

WOLFF, Cristina Scheibe. Mulheres da floresta: Uma história - Alto Juruá, Acre (1890-1945). São Paulo: HUCITEC, 1999. 